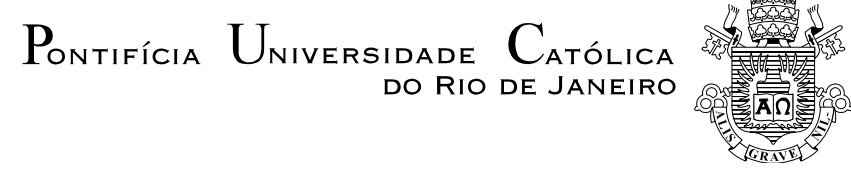

Renato dos Santos Gomes

\begin{abstract}
A formação do PVNC- Núcleo Vila
Operária: uma experiência de inclusão educacional
\end{abstract}

Dissertação de Mestrado

Dissertação apresentada ao Programa de Pós-Graduação em Serviço Social da PUC-Rio como requisito parcial para obtenção do título de Mestre em Serviço Social.

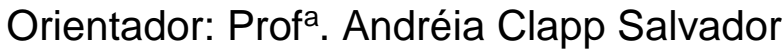




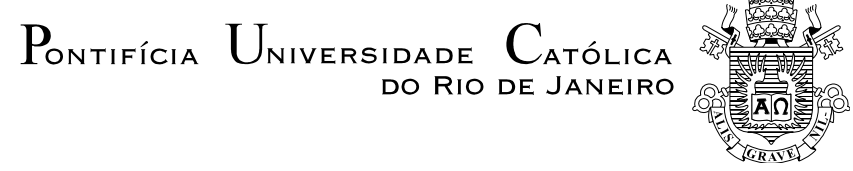

Renato dos Santos Gomes

\section{A formação do PVNC- Núcleo Vila Operária: uma experiência de inclusão educacional}

Dissertação apresentada como requisito parcial para obtenção do grau de Mestre pelo Programa de Pós-Graduação em Serviço Social do Departamento de Serviço Social do Centro de Ciências Sociais da PUC-Rio. Aprovada pela Comissão Examinadora abaixo assinada.

Profa. Andréia Clapp Salvador

Orientador

Departamento de Serviço Social - PUC-Rio

Prof. Rafael Soares Gonçalves Departamento de Serviço Social - PUC-Rio

Prof. Ramoflay Bicalho dos Santos UFRRJ

Profa. Mônica Herz

Vice-Decana de Pós-Graduação do Centro de Ciências Sociais - PUC-Rio

Rio de Janeiro, 28 de julho de 2015 
Todos os direitos reservados. É proibida a reprodução total ou parcial do trabalho sem autorização da universidade, do autor e do orientador.

\section{Renato dos Santos Gomes}

Graduou-se em Geografia e Meio Ambiente pela Pontifícia Universidade Católica do Rio de Janeiro, em 2004. Atualmente é coordenador - Pré-Vestibular para Negros e Carentes e professor da Associação Brasileira de Ensino Universitário. Tem experiência na área de Geografia, com ênfase em Teoria do Desenvolvimento Regional, atuando principalmente nos seguintes temas: educadoras e educadores da reforma agrária, estatuto da criança e do adolescente, encontro escola comunidade, gestão de políticas públicas e impacto social. Latu Senso em Saúde do Trabalhador e Ecologia Humana ENSP (FIOCRUZ).

Ficha Catalográfica

Gomes, Renato dos Santos

A formação do PVNC-Núcleo Vila Operária: uma experiência de inclusão educacional / Renato dos Santos Gomes; orientadora: Andréia Clapp Salvador. 2015.

82 f.: il. (color.) ; $30 \mathrm{~cm}$

Dissertação (mestrado) - Pontifícia Universidade Católica do Rio de Janeiro, Departamento de Serviço Social, 2015.

Inclui bibliografia.

1. Serviço social - Teses. 2. Prévestibular comunitário. 3. Política de ações afirmativas. 4. Movimento social. 5. Educação popular. 6. Militância. I. Salvador, Andréia Clapp. II. Pontifícia Universidade Católica do Rio de Janeiro. Departamento de Serviço Social. III. Título. 


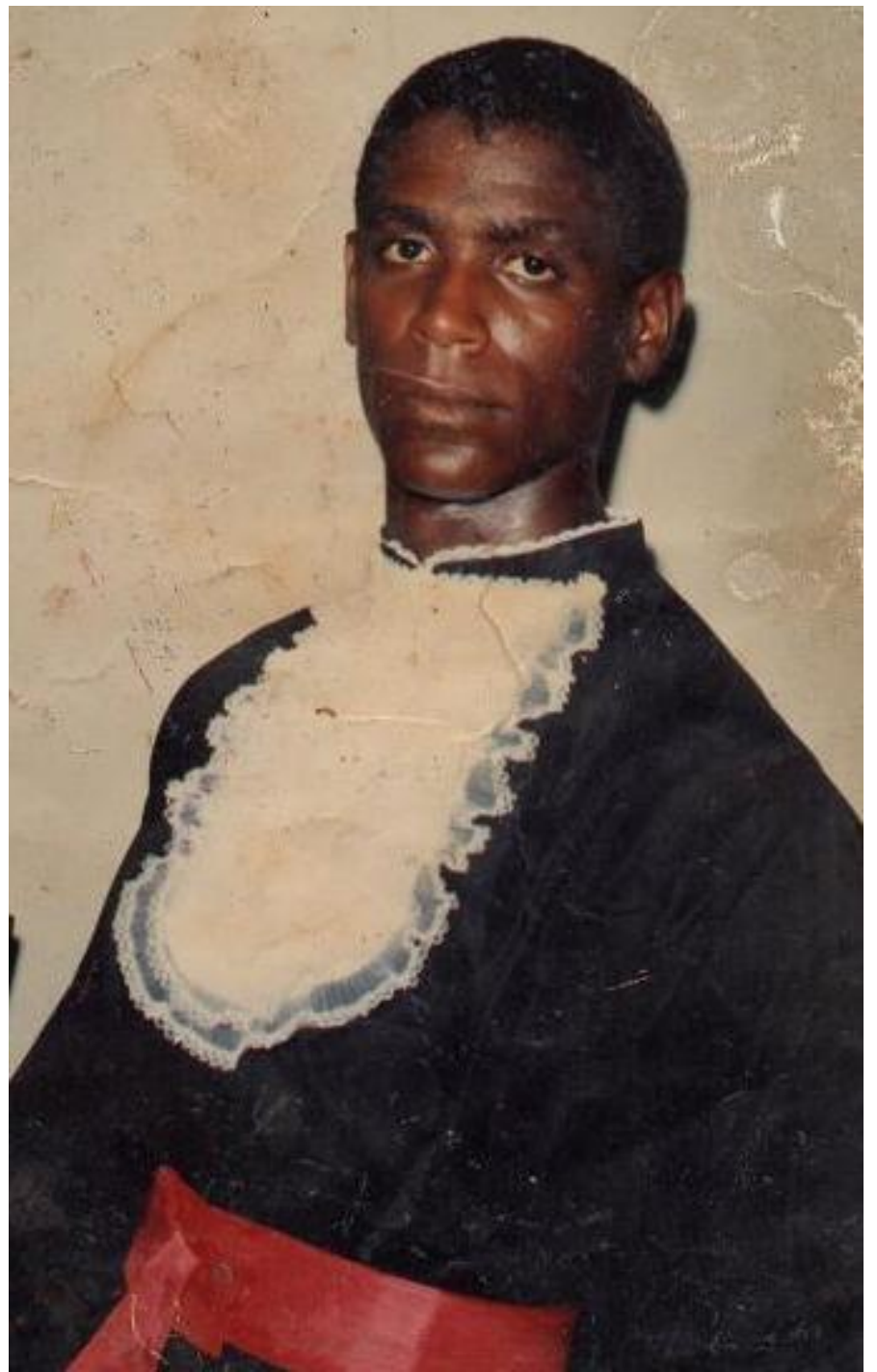

Dedico esta pesquisa ao companheiro Wellington Gomes (In memoriam), vítima da violência urbana, pela sua contribuição para a formação do grupo de estudo que, posteriormente, veio a se tornar o PVNC - Vila Operária. 


\section{Agradecimentos}

Aos meus pais, Maria de Lourdes dos Santos Gomes e José Clobis Gomes, pelo apoio incondicional aos meus estudos.

Aos meus irmãos, Alexandre, Ricardo, Eliani e Janice, pelas palavras de incentivo e pela confiança.

Aos meus sobrinhos e filho, Pedro, Matheus, Heitor e Renan.

À minha companheira Vanessa Alves Gomes sempre presente nos momentos difíceis e mais difíceis ainda.

Aos amigos do PVNC - Pré-Vestibular para Negros e Carentes, em especial, à família dos professores Marcelo e Vanessa pela acolhida e apoio.

Aos entrevistados pela belíssima contribuição para esse trabalho, em especial, ao senhor Salvador Marcelino que, infelizmente, veio a falecer durante a caminhada da pesquisa.

A todos que contribuíram para essa pesquisa com seus depoimentos enriquecedores.

Ao Programa de Pós-Graduação em Serviço Social (SER) e a seus funcionários pela receptividade e orientação do início ao fim de minha jornada acadêmica, em especial, à Joana Maria Felix da Silva. 
À professora Luiza Helena pelo seu comprometimento com os movimentos sociais, em especial, com os de educação popular.

Ao professor Dr., Ramofly Bicalho dos Santos, pela capacidade de compartilhar seu conhecimento com aqueles que ainda estão caminhando para uma formação de excelência.

Ao professor Dr., Rafael Soares Gonçalves, pela disponibilidade e colaboração.

À Orientadora Professora Dra. Andréia Clapp Salvador pela dedicação, carinho e paciência com o seu orientando. 


\section{Resumo}

Gomes, Renato dos Santos; Salvador, Andréia Clapp. A formação do PVNC- Núcleo Vila Operária: uma experiência de inclusão educacional. Rio de Janeiro, 2015. 82 p. Dissertação de Mestrado - Departamento de Serviço Social, Pontifícia Universidade Católica do Rio de Janeiro.

O presente estudo busca compreender como se deu o processo de constituição e formação do Pré-Vestibular - núcleo Vila Operária - que se localiza no município de Nova Iguaçu (Rio de Janeiro) e também identificar as motivações de seus idealizadores que levaram o surgimento desse movimento social e a sua importância para a comunidade local. Os pré-vestibulares comunitários, especialmente o PVNC - Vila Operária, vêm desde a década de 1990 formando jovens da classe trabalhadora e principalmente negros, para ingressarem nas Universidades públicas e privadas (com bolsas). A prioridade desse movimento social não é só favorecer uma classe menos privilegiada a ter uma disputa mais justa nos vestibulares, mas também formar um cidadão consciente e crítico dos valores da sociedade, qualificando-a assim para o mercado de trabalho e não para uma reprodução capitalista da mais valia. A presente pesquisa utilizou o método qualitativo que busca informações relevantes sobre o PVNC - Vila Operária para assim levantar as questões pertinentes ao objeto proposto, foram utilizadas entrevistas com os protagonistas que militaram para a construção desse núcleo. Além disso, a pesquisa buscou entender o conceito de "cultura e cidadania" oferecido pelo núcleo - Vila Operária e sua importância social, já que para o movimento essa disciplina pode contribuir para uma mobilidade social ascendente de seus alunos e para uma busca mais direcionada de seus direitos. As ações afirmativas debatidas dentro da disciplina "cultura e cidadania" como uma forma de reconhecimento de uma desigualdade imposta à população negra também compõem o campo de pesquisa dessa dissertação.

\section{Palavras-chave}

Pré-vestibular comunitário; política de ações afirmativas; movimento social; educação popular; militância. 


\section{Abstract}

Gomes, Renato dos Santos; Salvador, Andréia Clapp (Advisor). The constitution of PVNC - Core Workers' Village: An educational inclusion experience. Rio de Janeiro, 2015. 82p. MSc. Dissertation - Departamento de Serviço Social, Pontifícia Universidade Católica do Rio de Janeiro.

This study aimed to understand how was the process of constitution and formation of the Pre - Vestibular - Vila Operária- which is located in Nova Iguaçu (Rio de Janeiro) and also identify the motivations of its founders that led the emergence of this social movement and its importance to the local community. Community pre-vestibular, especially PVNC - Workers' Village, come from the 1990s training young working class and mostly black, to join in public and private universities (with Studentships). The priority of this social movement is not only favor a less privileged class to have a fairer dispute in the entrance, but also form a conscious and critical citizens of the values of society, describing it as well for the labor market and not for a capitalist reproduction of surplus value. This research used the qualitative method that seeks relevant information about PVNC - Workers Village for just raise the relevant issues to the proposed object, interviews were used with the protagonists who campaigned to build this core. In addition, the research sought to understand the concept of "culture and citizenship" offered by the core - Workers' Village and its social importance, since for the motion this discipline can contribute to upward social mobility of their students and for a more targeted search your rights. Affirmative action's discussed within the discipline "culture and citizenship" as a form of recognition of inequality imposed on black people also make up the field of research of this dissertation.

\section{Keywords}

Community pre-vestibular; affirmative action policy; social movement; popular education; advocacy. 


\section{Sumário}

Introdução

1. Os pré-vestibulares comunitários - A prática de um movimento social de educação popular

1.1. O Pré-Vestibular para Negros e Carentes - Uma proposta de inclusão de estudantes da classe trabalhadora nas Universidades

1.2. O PVNC como movimento de educação popular

1.3. PVNC núcleo Vila Operária e educação popular: um caso específico

1.4. O PVNC da Vila Operária em Nova Iguaçu - A formação de estudantes-trabalhadores para a inserção nas Universidades

1.5. As ações afirmativas - Uma política voltada para grupos que vivem em condições de desigualdade social

2. O Pré-Vestibular Vila Operária - A sua gênese e formação

2.1. O processo de construção do PVNC - Vila Operária e seus protagonistas

2.2. A formação do núcleo Vila-Operária

2.3. A fase inicial de formação do núcleo PVNC Vila Operária: fatos importantes

2.4. Por que ser um ativista do PVNC

2.5. A importância do PVNC para a comunidade 62

2.6. Formação da coordenação e seleção de docentes 70 e discentes

2.7. Depoimentos de ex-alunos acerca da própria trajetória do PVNC - Vila Operária

3. Conclusão

4. Referências Bibliográficas 


\section{Lista de Figuras}

Figura 1- Laurita Ferraz: uma das protagonistas do Núcleo Rancho Novo

Figura 2- Em 1994, os movimentos sociais começam a ganhar destaque, elevando o número de alunos carentes nas universidades

Figura 3- Colégio Estadual Vereador Percy Batista Crispin: local das realizações das aulas do núcleo Rancho Novo

Figura 4- As assembleias eram frequentemente noticiadas nos jornais internos dos PVNC,s

Figura 5- Uma das salas do PVNC - Vila Operária: Ao fundo ainda há 3 carteiras doadas pela UFRRJ

Figura 6- Praça Eneas: local da aula do dia $1^{\circ}$ de maio de 1999

Figura 7- Parte externa do Colégio Seis de Janeiro

Figura 8- Parte interna do Colégio Seis de Janeiro

Figura 9- $\quad$ Festa Junina do Colégio Seis de Janeiro: interação entre alunos do PVNC e a escola

Figura 10- Professora Letícia: homenagem pelo seu ingresso no Doutorado

Figura 11- Dona Lourdes: foto presente no álbum "llustres e Anônimos". Trabalho realizado por Paulo Santos

Figura 12- Em 2010, O PVNC- Vila Operária fez parte da reportagem do Jornal "O Dia" sobre os prévestibulares

Figura 13- Ex-aluno e agora professor do PVNC,

Jonatan Magella, foi capa da revista "Educação" no ano de 2014

Figura 14- Seu Salvador: articulador político para implantação do núcleo PVNC

Figura 15- Paróquia de São Judas Tadeu: local onde funcionou

o Núcleo PVNC - Heliópolis

Figura 16- Futebol: momento de integração entre professores, 
alunos e comunidade

Figura 17- Baile dos Calouros: na parte superior da foto um 66 pedaço do cartaz com os nomes dos aprovados

Figura 18- Quadro onde os alunos aprovados assinam os seus nomes. O antigo quadro foi danificado numa enchente

Figura 19- Feijoada do Pré sendo preparada

Figura 20- Capoeira do PVNC: evento acontece anualmente 70 durante a "Feijoada do Pré 
A violência destrói o que ela pretende defender: a dignidade da vida, a liberdade do ser humano.

(João Paulo II) 


\title{
Introdução
}

As inquietações que nos levam a desenvolver este trabalho acerca do PVNC se justifica pela necessidade de registrar a história da formação do prévestibular e mais especificamente o PVNC, Vila Operária, um movimento popular voltado para a inclusão de estudantes no ensino superior.

Segundo Nascimento:

\begin{abstract}
Como uma ação coletiva popular e, portanto, como um movimento social, o PréVestibular para Negros e Carentes construiu a possibilidade de transformar o trabalho de educação popular, através do ensino pré-vestibular, em uma forma de ação político-cultural e articulação popular, além de fortalecer a luta de combate ao racismo, à discriminação e à exclusão. Seu surgimento proporcionou expressão ao trabalho popular de preparação de estudantes para o vestibular e, de certa forma, fortaleceu a luta das entidades e organizações que atuam no combate à discriminação e no questionamento da atual (e quase hegemônica) lógica neoliberal de relações sociais. (Nascimento, 1999, p. 24).
\end{abstract}

Sendo assim, buscou-se discutir como esse curso de perfil comunitário atua na perspectiva de formação (preparação para o vestibular) e conscientização de jovens de classes populares para cursar uma universidade e como os pré-vestibulares se constituem como uma organização popular voltada a educação popular.

De início, dois motivos me levaram à escolha desse núcleo do PVNC como fonte de análise. Primeiramente, por ser um dos fundadores do núcleo em 1996 e dois anos depois, tornar-me professor. Desde então, leciono, coordeno e vivencio as histórias que cada aluno trás de sua vida antes de entrar numa universidade com seus sonhos e perspectivas e depois como estudante de ensino superior com suas dificuldades e conquistas. Como se nota, o parágrafo escrito na primeira pessoa gramatical demonstra o quanto é particular essa pesquisa.

Outro ponto relevante para o desenvolvimento dessa pesquisa é o número reduzido de material específico sobre a história dos PVNC's. Acreditamos que ao construir esse estudo, colaboremos para o registro da história de um núcleo PVNC que, de certa maneira, traduz uma realidade muita próxima de todos os demais campos de atuação desse movimento social.

Para isso, buscamos compreender todo o movimento social proporcionado pelo curso Pré-Vestibular para Negros e Carentes, desde o seu surgimento, 
identificando assim o seu contexto histórico, analisando suas propostas pedagógicas, sua estrutura, além de sua área de atuação no que tange à sociedade como um todo, ou seja, os motivos pelos quais esse modelo de movimento social age em prol de uma demanda inclusiva.

No desejo de investigar os aspectos sociais, culturais e políticos de que essa pesquisa tem sua justificativa na exploração de determinados aspectos sociais que envolvem a formação dos pré-vestibulares populares (PVNC). Ao explorar e difundir esse tema, contribuiremos não só para o acervo bibliográfico e histórico desse grande movimento popular, mas também para sua própria caracterização. Podemos dizer que essa pesquisa, mesmo sendo de caráter particular (já que examina um local específico de atuação), pode refletir de maneira coletiva as experiências vivenciadas e proporcionadas por diversas unidades espalhadas na área metropolitana do Rio de Janeiro. Construir uma pesquisa pautada nas próprias experiências e nas experiências de outros atores desta história torna o trabalho ainda mais prazeroso, uma vez que todos os assuntos e questões analisadas já fazem parte da nossa vida. Ressalta-se que o presente estudo está pautado numa análise crítica baseada em leituras específicas acerca da temática.

Desta forma, os objetivos da presente pesquisa são o de analisar a história do Pré-Vestibular para Negros e Carentes, núcleo Vila Operária, situado no município de Nova Iguaçu, RJ, através da história de seus educadores/ativistas, identificando as principais lideranças políticas que participaram da formação do núcleo Vila Operária e mostrando suas principais propostas e valores.

A presente pesquisa baseou-se teoricamente em alguns autores que analisam a questão da educação popular e políticas de ação afirmativa. Desse modo, autores como Paulo Freire, Alexandre Nascimento, Renato Emerson do Santos, Andréia Clapp entre outros serão a base dessa dissertação que tem como um dos objetivos estudar a história da organização do Pré-Vestibular para Negros e Carentes, núcleo Vila Operária.

Por se tratar de um pré-vestibular voltado para comunidade negra e/ou oriunda de escola pública, torna-se necessário discutir a questão da desigualdade social, econômica e racial, informando-Ihes a realidade em que estão inseridos. Para tal são utilizados autores como Ricardo Henriques Em seu artigo "Desigualdade Racial no Brasil: Evolução das Condições de Vida na Década e 90", Henriques relata: 
A intensa desigualdade racial brasileira associada a formas usualmente sutis de discriminação racial, impede o desenvolvimento das potencialidades e o progresso social da população negra. O entendimento dos contornos econômicos e sociais da desigualdade entre brasileiros brancos e brasileiros afro-descendentes apresenta-se como elemento central para se construir uma sociedade democrática, socialmente justa e economicamente eficiente. (Henriques, Ricardo, 2001, p.2)

Para abordar, mais especificamente, as práticas políticas e pedagógicas adotadas pelos PVNC,s, os autores Alexandre Nascimento e Renato Emerson nos servem como base teórica para que possamos desenvolver nossa pesquisa sobre o núcleo - Vila Operária. Esses autores são oriundos desse movimento social e produziram materiais que possibilitam uma maior reflexão sobre as políticas públicas e educacionais voltadas para a população menos favorecida. De acordo com Alexandre do Nascimento, o Movimento dos Cursos PréVestibulares Populares do ponto de vista teórico se caracteriza como:

Um ator social inovador e produtivo, cuja produção organiza, por meio de uma resistência criativa, uma luta política por inclusão não subordinada e, como tal, pela universalização dos direitos e democratização das instituições de ensino. (Do Nascimento, 2012 p. 54)

Em relação às políticas de ação afirmativa, Andréia Clapp, autora que trata da inclusão de alunos negros e pobres nas universidades, mais especificamente na PUC - Rio, é uma das principais referências para a pesquisa. Segundo Clapp (2010), "A política afirmativa é, geralmente, reconhecida como um instrumento político voltado para a inclusão de grupos subordinados ou subalternizados, muito embora seu campo de intervenção seja muito maior".

A pesquisa de campo é baseada na proposta de analise qualitativa. Para Minayo (2001), "a metodologia qualitativa trabalha com o universo de significados, aspirações, crenças, valores e atitudes, o que corresponde a um espaço mais profundo das relações, dos processos e dos fenômenos que não podem ser reduzidos à operacionalização de variáveis" (p. 22).

Quanto aos procedimentos técnicos de coleta dados, utilizou-se a entrevista semi-estruturadas, ${ }^{1}$ uma vez que a entrevista semi-estruturada é a que atende melhor a proposta da pesquisa, já que delimita o volume das informações, o que facilita para o maior debate do tema em pesquisa buscar

\footnotetext{
${ }^{1}$ As entrevistas semi-estruturadas combinam perguntas abertas e fechadas, onde o informante tem a possibilidade de discorrer sobre o tema proposto. O pesquisador deve seguir um conjunto de questões previamente definidas, mas ele o faz em um contexto muito semelhante ao de uma conversa informal.
} 
informações dos ativistas que colaboraram para o surgimento e manutenção do núcleo Vila Operária.

Por fim, sobre a organização e análise dos dados, destacamos que, baseado numa análise qualitativa, buscou-se documentar a historicidade do PVNC - Vila Operária, através dos relatos, colhidos em campo, dos colaboradores desse movimento social. Para isto foram entrevistados 4 professores do PVNC - Vila Operária (Altair Lisboa, Ramofly Bicalho, Alexandre Lino e Alzivane Barreira) que fizeram parte de sua construção. Além dos docentes, contribuíram para a entrevista Sr. Salvador Marcelino (articulador político), Laurita Ferraz (colaboradora). Buscou-se identificar assim a gênese do Pré-Vestibular e os seus principais protagonistas, os fatos importantes e as razões de sua construção. Além disso, alguns depoimentos de personagens importantes que surgiram durante a militância do Vila Operária também contribuirão para enriquecimento desta pesquisa. 


\title{
1 \\ Os pré-vestibulares comunitários - A prática de um movimento social de educação popular
}

Os pré-vestibulares comunitários começaram a ganhar destaque no Rio de Janeiro nos anos 90, no entanto, sua origem se dá no ano de 1975, em uma organização do movimento negro, situada no município de São Gonçalo. (Alexandre,1999)

Os PVNC,s (Pré-Vestibular para Negros e Carentes) se caracterizam como um movimento social voltado para a educação popular com um corte racial. Com uma grande demanda de alunos oriundos de escola pública e/ou com baixa renda familiar, vários núcleos foram criados por todo Rio e Grande Rio. É nesse contexto que o PVNC - núcleo Vila Operária (antigo núcleo Rancho Novo) passa a desenvolver sua militância, atendendo os anseios de uma comunidade, até então, desprovida de um movimento de caráter educacional. O principal objetivo desse núcleo social era proporcionar uma mobilização no que tange educação popular, visando além de uma conscientização social, cultural e política, a possibilidade de um estudante ingressar numa Universidade, seja ela pública ou privada por meio de bolsas de estudo. Como afirma Renato Emerson:

\begin{abstract}
A construção do movimento Pré- Vestibular para Negros e Carentes (PVNC) é um desdobramento de um conjunto de estratégias do Movimento Negro nas décadas de 1970 e 1980, dentre as quais podemos destacar a escolarização dos negros como processo de construção de novas lideranças e fortalecimento de outras lideranças, e a capitalização de militantes da luta anti-racismo em diferentes espaços de luta e intervenção social, que vai levar a este novo movimento (o prévestibular) uma cultura de convergência e hibridação de valores, leituras do social e formas de atuar. (Santos, 2003, p.229)
\end{abstract}

Sendo assim, é fundamental conhecermos alguns dos princípios desenvolvidos pelos movimentos sociais no que toca à luta por uma educação popular. Suas bandeiras, projetos, perspectivas e utopias. A formação política dos trabalhadores/as e a valorização da consciência social são alguns dos desafios.

Para entender melhor toda a militância social voltada para educação e trabalho, mais especificamente a prática dos PVNCs, é preciso estar engajado com o momento econômico e político do Brasil nos anos 90. Primeiramente, o Brasil defrontava-se com o grande desafio de superar as crises econômicas de décadas passadas e ao mesmo tempo se enquadrar em um novo modelo 
econômico internacional conhecido como capitalismo informacional. Segundo Castells, a economia é informacional porque:

A produtividade e a competividade de unidades ou agentes nessa economia (sejam empresas, regiões ou nações) dependem basicamente de sua capacidade de gerar, processar, e aplicar de forma eficiente a informação baseada em conhecimentos. (Castells, 1999, p.87)

Com a ascensão da economia global e do neoliberalismo, confere-se uma nova qualidade ao sistema produtivo que passa a se basear no sistema de administração da produção que consiste na utilização de maquinários, de tecnologias sofisticadas e com terceirização de múltiplas atividades. Este novo momento provocou, no mínimo, a redução dos direitos sociais.

Nesta transformação industrial uma grande parte dos operários brasileiros não foi absorvida por este novo modelo implantado pela nova lógica da indústria (informática e a robótica) gerando o desemprego e a precarização das condições de trabalho. Com a nova implantação da indústria técnico-científica coube ao filho do operário ir à busca de conhecimento para assim se inserido neste novo modelo industrial político.

Com a necessidade da classe trabalhadora se inserir no mercado de trabalho, que consequentemente ficou mais exigente, os movimentos sociais começam a realizar uma mobilização voltada para a educação popular com o objetivo de colocar filhos de operários nas universidades públicas.

Através dessas inquietações, os PVNCs surgem com o objetivo, num primeiro momento, de dialogar e refletir sobre a população negra e trabalhadora, oriunda de escolas públicas, para ,posteriormente, mostrar a importância de ingresso num curso superior, até então distante da realidade de grande parte desses alunos, a priori, moradores da Baixada Fluminense ${ }^{2}$. A partir desse momento, nasce uma militância voltada para a conscientização e mobilização de uma camada social que, até então, estava desorientada e descrente da importância de se ter um nível superior. Vale lembrar que nos anos 90 os prévestibulares ganharam maior visibilidade política e expressão territorial, uma vez que a sociedade se deparou com uma nova transformação no mundo do trabalho. Transformação essa que exigiu uma qualificação mais apurada, via universidade ou cursos técnicos, do novo operariado brasileiro. Por isso, a necessidade de uma militância social, nesse caso, voltada para o campo

\footnotetext{
${ }^{2}$ A Baixada Fluminense, localizada na região metropolitana do Estado do Rio de Janeiro, é composta por 13 municípios Belford Roxo, Duque de Caxias, Guapimirim, Itaguaí, Japeri, Magé, Mesquita, Nilópolis, Nova Iguaçu, Paracambi, Queimados, São João de Meriti, Seropédica.
} 
educacional.

No entanto, para que haja uma militância social é necessário que os prévestibulares comunitários ajudem no aprendizado da construção de utopias sociais, uma vez que são elas que permitem relacionar a identidade pessoal com as grandes questões da humanidade. Apenas desta forma, a militância é capaz de transformar estas utopias em projetos que mobilizem grandes massas, e em obras que já iniciem sua concretização.

A militância é entendida assim num sentido amplo, de engajamento em torno de grandes causas, ações pelo bem de outras pessoas, envolvimento em processos de transformação social, que também podem desembocar na militância política ou na participação direta em organizações, movimentos sociais e partidos políticos.

Nesse sentido, a presente dissertação tem a intenção de compreender a trajetória de um movimento social surgido no início da década de 90 - o PréVestibular para Negros e Carentes (PVNC), mais especificamente o PVNC Núcleo Vila Operária, localizado no município de Nova Iguaçu. Com este estudo, pretendemos conhecer a gênese deste Pré-Vestibular comunitário e o percurso vivido por professores ou colaboradores pioneiros do PVNC, relatando sua militância durante os anos de luta. Considera-se aqui que estes ativistas políticos possam contribuir para a "gestação de embriões de democratização", socialização de poder, superação dos desafios, afirmação de identidades e seres humanos preocupados com o fortalecimento do movimento social.

Vale salientar que os PVNC's não atuam somente como um curso preparatório para os vestibulandos negros ou pobres, já que esse movimento tornou-se um símbolo de luta contra o racismo. Com sua solidificação, passou a ser a voz capaz de promover debates sobre a democratização do ensino superior no Brasil, tornando-se, em alguns momentos, a voz do povo nas próprias instâncias governamentais.

A ação dos pré-vestibulares comunitários tem uma proposta direta no sentido de possibilitar uma maior igualdade social, constituir espaços mais diversificados e principalmente ampliar a representatividade de grupos sociais que vivem em condições de desigualdade social. Sendo assim, a perspectiva de inclusão de estudantes negros, pobres, indígenas em cursos universitários possibilita uma maior mobilidade social destes grupos que, historicamente, representam ainda uma pequena parcela do quantitativo total de alunos. 
No estado atual das coisas, a exclusão social de que os negros são as principais vítimas no Brasil deriva de alguns fatores, entre os quais figura o esquema perverso de distribuição de recursos públicos em matéria de educação. A Educação é a mais importante entre as diversas prestações que o indivíduo recebe ou tem legítima expectativa de receber do Estado". (Gomes, 2001, p. 138)

Desse modo, sabemos que a educação é um dos fatores mais importante para uma mobilidade social e econômica e quando esta é "negada" ao negro, percebemos o quanto a população negra sempre esteve a margem da sociedade educacional, principalmente no ingresso as universidades. Segundo Joaquim B. Barbosa:

A chave para se entender porque existem tão poucos negros nas universidades públicas brasileiras, e quase nenhum nos cursos de maior prestígio e demanda: os recursos públicos são canalizados preponderantemente para as classes mais afluentes, restando aos pobres (que são majoritariamente negros) "as migalhas" do sistema". (Gomes, p. 139, 2001)

Neste caminhar, o núcleo Vila Operária procura fazer campanhas de discussão sobre a população negra marginalizada que durante décadas thes foram negado o direito básico e humano que se chama educação, pois sabemos que a melhor maneira de valorizar o conhecimento e a história de um povo é lidando o princípio básico dos direitos humanos, que é a educação.

De acordo com Andréia Clapp:

Em 2003, com a lei de cotas para estudantes negros(as), esse tema começou a despontar na mídia e na sociedade de modo geral, em um debate que tem sido bastante conflituoso e que tem dividido opinião entre os que são a favor e os oponentes". (Clapp, 2010, p.7).

As políticas de ações afirmativas conseguiram trazer de forma evidente a discrepância sobre o ingresso de alunos negros nas universidades, mostrando para toda sociedade brasileira através de dados estatísticos a relação entre o número de alunos brancos e negros nas universidades, deixando claro que o quantitativo de alunos brancos é superior em números no que tange a quantidade entre brancos e negros estudantes.

As políticas de viés afirmativo aparecem como uma resposta às exigências feitas por grupos sociais (como negros, mulheres, homossexuais, portadores de deficiência, entre outros) por direitos coletivos e culturais. Esses grupos que vêm se organizando como movimentos sociais, principalmente a partir de décadas de 1980 e 1990, tem lutado não só por direitos que historicamente Ihes têm sido negados, como também pelo reconhecimento de suas especificidades em quanto grupo social. (Clapp, 2010, p.8) 
Dentre esses grupos, temos o PVNC que procura trabalhar em seus núcleos conteúdos formais e de cidadania o que vem possibilitando a inserção de um número expressivo de estudantes da classe popular nas Universidades do Brasil.

\title{
1.1.
}

\section{O Pré-Vestibular para Negros e Carentes - Uma proposta de inclusão de estudantes da classe trabalhadora nas Universidades}

Os pré-vestibulares comunitários vêm ao longo das duas últimas décadas realizando um trabalho de educação popular voltado para a formação de estudantes de classes populares mais especificamente negros e negras. A origem dos pré-vestibulares populares vai ocorrer a partir da ação de movimentos sociais urbanos que se consolidam principalmente a partir da formação do PVNC. Segundo Nascimento:

\begin{abstract}
Embora tenham proliferado e se tornado politicamente expressivos ao longo dos anos 1990, os cursos pré-vestibulares não surgiram nesta década. Em 1975, por exemplo, o centro de Estudos Brasil-África (Ceba), uma organização do movimento negro, situada no Município de São Gonçalo, no Estado de Rio de Janeiro, organizou um curso pré-vestibular para negros. Podemos citar também o curso pré-vestibular do projeto "Universidade para Trabalhadores", da Associação dos Trabalhadores em Educação da Universidade Federal do Rio de Janeiro (Assufrj, atual Sinturfrj), criado em 1986. (Nascimento, 1999, p.69)
\end{abstract}

Porém somente no início dos anos 1990 é que os movimentos de educação popular (pré- vestibulares comunitários ou sociais) ganham visibilidade política e expressão territorial, tendo como o principal percussor deste momento o primeiro Pré- Vestibular para Negros e Carentes (PVNC) que surgi nas bases da Igreja Católica, mas especificamente na Baixada Fluminense em São João de Meriti na lgreja da Matriz tendo como coordenadores Frei David Raimundo dos Santos, Antônio Dourado, Luciano de Santana Dias e Alexandre do Nascimento. (Emerson, 2003).

De acordo com Emerson (2003), o objetivo do curso era inserir alunos negros e carentes nos vestibulares da PUC-SP e das Universidades Públicas do Estado do Rio de Janeiro tendo em vista a possibilidade de bolsa de estudos na PUC- SP para alunos oriundos do movimento negro, porém uma proposta que não se consolidou. 
A construção do movimento Pré- Vestibular para Negros e Carentes (PVNC) é um desdobramento de um conjunto de estratégias do Movimento Negro nas décadas de 1970 e 1980, dentre as quais podemos destacar a escolarização dos negros como processo de construção de novas lideranças e fortalecimento de outras lideranças, e a capitalização de militantes da luta anti-racismo em diferentes espaços de luta e intervenção social, que vai legar a este novo movimento (o prévestibular) uma cultura de convergência e hibridação de valores, leituras do social e formas de atuar. (Emerson, 2003, p. 229)

No início de década 90, muitos movimentos populares ganharam força, como o Movimento dos Trabalhadores Rurais Sem Terra e o Movimento de Educação Popular, impulsionados pelas manifestações que ficaram conhecidas como "Fora Collor". No entanto, para entender de maneira histórica esse momento, é preciso demonstrar o percurso que culminou na ascensão e no fortalecimento dos movimentos populares no Brasil.

Para começar em 1989, houve a primeira eleição pelo voto direto, pósditadura militar. Com isso, foi eleito o presidente Fernando Collor de Mello. Seu governo implantou o "Plano Brasil Novo" (Plano Collor), contudo, a sua execução foi desastrosa, uma vez que, contradizendo as suas promessas de campanha, não houve o equacionamento da dívida externa e a inflação do país não foi controlada. Além disso, através de seus planos econômicos, o governo Collor confiscou os depósitos bancários em conta corrente e na caderneta de poupança. O presidente também foi denunciado num esquema de corrupção juntamente com o seu tesoureiro de campanha eleitoral.

Com a instabilidade política e econômica do Governo e com o pensamento neoliberal $^{3}$, a população começa a se organizar em virtude da grande insatisfação do modelo vigente. Houve assim uma grande mobilização social que culminou, em 1992, no impeachment do presidente Fernando Collor de Mello.

Nessa conjuntura política, surge o PVNC (pré-vestibular para negros e carentes), adquirindo esta riqueza histórica e se transformando em um grande movimento transformador e revolucionário de educação popular urbano do Rio de Janeiro e do Brasil, tendo como bandeira de luta: o enfrentamento das questões raciais de exclusão da população de baixa renda(carentes desprovidas do sistema econômico brasileiro) e do acesso as Universidades brasileiras. O movimento começa a ganhar adeptos e simpatizantes da causa da exclusão educacional e durante as décadas de 1990 e 2000 surgiram diversos núcleos na região metropolitana do Rio de Janeiro, como os núcleos de Belford

3 O neoliberalismo é em primeiro lugar uma teoria das práticas político-econômicas que propõe que o bem-estar humano pode ser melhor promovido liberando-se as liberdades e capacidades empreendedoras individuais no âmbito de uma estrutura institucional caracterizada por sólidos direitos a propriedade privada, livres mercados e livre comércio. (HARVEY, 2008) 
Roxo, São João de Meriti, Tijuca e Jacarepaguá.

Este crescimento dos núcleos não significa que todos tinham a bandeira racial como ponto principal de luta. Como se pode perceber na experiência do PVNC - Núcleo Vila Operária, que é o nosso objeto de pesquisa. O que se tornaria núcleo Vila Operária aparece no cenário do PVNC, em 1997, com o "corte de classe trabalhadora" com objetivo de inserir trabalhadores do setor secundário (setor industrial, construção civil, entre outros desse segmento) nas Universidades. Pois este núcleo é formado por jovens militantes do partido dos trabalhadores ou simpatizantes do mesmo e tem como bandeira a discussão trabalhista, neste momento em que o país estava vivendo uma grande transformação econômica neoliberal e política industrial, acarretando processo de demissões voluntárias, desemprego estrutural, este período ficou conhecido como "década frustrante" (1990).

Embora houvesse uma direção política do PVNC, expressa através da própria carta de princípios, os núcleos foram construindo suas histórias particulares conforme seus membros e história local.

\begin{abstract}
A multiplicidade que constitui o movimento dos cursos pré-vestibulares populares age produzindo exercícios e propostas de processos de democratização: mobilização e organização de atividades de ensino de conteúdos a fim de capacitar estudantes pobres e negros para os concursos públicos de admissão às instituições de ensino superior, com afirmação do direito ao ensino superior. (Nascimento, 1999, p. 84)
\end{abstract}

Com o objetivo de proporcionar o acesso da classe trabalhadora e negra aos concursos públicos e às Universidades, o pré-vestibular para negros e carentes tem como filosofia de trabalho inserir os alunos em patamares talvez "inimagináveis, demonstrando assim a força de luta de um grupo determinado, de um povo marginalizado em todo o seu período histórico de vida". A intenção do PVNC é que o estudante veja no curso a possibilidade de mudar a sua trajetória de vida.

Com toda essa perspectiva, o projeto vai ganhando cada vez mais força e com isso atraindo militantes em prol da luta contra o racismo e desigualdade social. Desse modo, o PVNC passou a se diferenciar dos outros movimentos de educação popular urbano, criando estruturas organizacionais como Assembleias Gerais, conselhos, Jornal informativo, seminários, fóruns, reflexões pedagógicas, coordenações Regionais.

As Assembleias Gerais era um momento de tomada de decisões democráticas das diretrizes de lutas em prol da pedagogia do movimento social. 
O Jornal informativo repassava as decisões tomadas nas assembleias e nos, divulgando também datas de seminários, fóruns e de outras manifestações futuras.

Esses encontros eram geralmente realizados nos finais de semanas, os conselhos eram constituídos por dois ou três representantes de cada núcleo e as Assembleias tinham a participação dos núcleos juntamente com seus alunos, professores e coordenadores. Considera-se que era um dos momentos mais importantes do movimento enquanto política de afirmação e movimento de transformação coletiva, pois vários alunos e professores tinham a possibilidade de trocar informações e conhecer mais a realidade de cada núcleo e com isso o movimento como um todo se fortalecia.

Através desses encontros é que se direcionava a política do movimento e, muitas das vezes, com grandes embates, com objetivo de fortalecer a permanência dos alunos nas universidades. Diferentes visões faziam das Assembleias um grande palco de disputa política em que, muitas das vezes, o tema principal era os alunos da PUC-RJ e das universidades públicas que, aprovados no vestibular, tinham que dar retorno ao Pré, no entanto, alguns destes não retornavam.

No início de formação do PVNC, surgem algumas correlações internas de forças e campos de disputa tais como:

- $\quad$ Alunos PUC x Universidade Pública

- Militantes por bolsas $\times$ Alunos militantes

Esses encontros tornaram-se novo campo de disputa política, no qual se configurou dois grupos distintos: os estudantes da PUC e os das Universidades Públicas. Os estudantes da PUC eram considerados nas assembleias "militantes por bolsa", por serem vistos como estudantes que "lutavam" pela garantia de bolsa, já que a PUC é Universidade privada.

\section{Formação dos núcleos:}

Entre os diversos núcleos do PVNC, alguns pontos eram comuns. Emerson caracteriza a formação dos núcleos PVNC a partir de três pontos:

O primeiro ponto intitula-se "autogestão": 
Boa parte dos núcleos é coordenada pelos próprios alunos, ex-alunos e professores. Este aspecto, de um lado, confere uma autonomia decisória aos núcleos que, diante do afastamento e da tensão entre as agendas e enfrentamentos correntes no seu cotidiano e o plano dos fóruns coletivos (torna-se um forte componente a facilitar sua ruptura com o movimento organizado em rede). (Santos, 2003, p. 230-231)

$\mathrm{Na}$ fase inicial, tratando-se de um movimento em formação muitas dificuldades surgiam. Primeiramente, o tempo para a formação política do movimento era curto (9 meses). Dentro desses noves meses, havia também a necessidade de preparar os alunos para o tão concorrido vestibular. No entanto, por falta de militantes para assumir um cargo como a de coordenador, alguns alunos desempenhavam esse papel. Por este motivo, não há nenhum estranhamento nos espaços formais de algumas decisões políticas por parte dos alunos, ao contrário, considera-se uma atitude louvável em uma correlação de força.

O segundo ponto ressaltado por Emerson destaca a "quase inexistência de compromissos financeiros":

\begin{abstract}
Normalmente os alunos contribuem em algo em torno de $10 \%$ do salário mínimo, verba destinada à aquisição do material didático necessário, alimentação (nos cursos que funcionam aos sábados e domingos durante todo o dia), custeio de passagem para os professores e, se possível ajuda aos alunos no pagamento das taxas de inscrição no vestibular, quando não conseguem isenção. Este traço que tem a marca flagrante da ala cristã de influência franciscana, hegemônica na construção do PVNC - condiciona uma alergia de grande parte dos prévestibulares populares ao financiamento público ou empresarial. (Santos, 2003, p.231).
\end{abstract}

Estes dois aspectos levantados por Emerson significam que os prévestibulares para negros e carentes (PVNC) tinham em sua essência uma organização funcional do cotidiano para suprir algumas necessidades financeiras e até mesmo ocupacionais. O PVNC entendia que buscar recursos financeiros poderia descaracterizar o "movimento revolucionário", pois acredita em sua própria autogestão financeira se colocando sempre contra o modelo neoliberal. No caso de haver, uma possibilidade de investimento no projeto, teria que se criar uma comissão para o gerenciamento deste investimento e ao mesmo tempo um amadurecimento por parte de seus militantes para não confundir os preceitos dos movimentos com as propostas das ONG,S.

Já o terceiro ponto ressaltado pelo autor é do "trabalho voluntário": 
Dos professores e coordenadores, num contexto marcado pela desmobilização e esvaziamento de militância e diversos movimentos sociais no Brasil, e, paradoxalmente, pela emergência de valores como a solidariedade e a participação, ainda que marcados por uma negação da dimensão política de sua participação. Este último aspecto, o trabalho voluntário, é fundamental na estruturação da rede, na medida que o pré-requisito necessário para alguém ingressar no PVNC é além do domínio dos conteúdos de cada matéria, no caso dos professores - o próprio desejo de ingressar no movimento..." (Santos, 2003, p.232)

Para o PVNC - Vila Operária, acolher o voluntariado é o primeiro passo para torná-lo um militante na educação popular para que ele possa dar assim a sua contribuição no tempo que estiver no Núcleo.

\section{2. \\ O PVNC como movimento de educação popular}

Na "Carta de Princípios", o Pré- Vestibular para Negros e Carentes (PVNC) é caracterizado como "um movimento de educação popular, laico e apartidário, que atua no campo da educação através da capacitação para o vestibular, de estudantes economicamente desfavorecidos em geral e negros(as) em particular." Sendo assim, é preciso reconhecer o conceito e as justificativas para por em prática a sabedoria popular em prol da educação.

O que justifica a Educação Popular é o fato de que o povo, no processo de luta pela transformação popular, social, precisa elaborar o seu próprio saber... Estamos em presença de atividades de educação popular quando, independentemente do nome que levem, se está vinculando a aquisição de uma saber (que pode ser muito particular ou específico) com um projeto social transformador. A educação é popular quando, enfrentando a distribuição desigual de saberes, incorpora um saber como ferramenta de libertação nas mãos do povo. Pelo que foi exposto antes, o fato é que se a educação popular pode ser entendida como uma atividade específica (não é toda ação assistencial, de trabalho social ou de política educativa) ela, por outro lado, não requer ser realizada no interior do sistema educativo formal, separada do conjunto de práticas sociais dos indivíduos. Muito ao contrário, a educação popular vem sendo desenvolvida no interior de práticas sociais e políticas e é aí precisamente onde podem residir a sua força e a sua incidência". (La Educación Popular Hoy em Chile: Elementos para Definiria, ECO, Educación y Solidariedad sem indicação de autor, p. 9)

O PVNC, como um movimento de educação popular, não se restringe ao aprendizado de conteúdos específicos transmitidos por técnicas para a aprovação do vestibular. Desse modo, procura debater com seus alunos a relação do conteúdo para que eles possam compreender a importância da disciplina apresentada. Pois ao longo do ano, procura transmitir aos discentes 
que passar no vestibular é uma consequência do trabalho apresentado, porque mais do que obter aprovação é compreender a estrutura educacional brasileira especificamente ao ensino fundamental e médio. Brandão (2006) cita três tendências em seu livro "O que é educação popular" para o reconhecimento de uma educação popular.

Três tendências sucessivas podem ser reconhecidas: 1) a educação popular é, em si mesma, um movimento de trabalho pedagógico que se dirige ao povo como um instrumento de conscientização etc.; 2) a educação popular realiza-se como um trabalho pedagógico de convergência entre educadores e movimentos populares, detendo estes últimos a razão da prática e, os primeiros, uma prática de serviço, sem sentido em si mesma; 3) a educação popular é aquela que o próprio povo realiza, quando pensa o seu trabalho político em qualquer nível ou modo em que ele seja realizado, de um grupo de mulheres a uma frente armada de luta - e constrói o seu próprio conhecimento. Neste último caso, a educação popular realiza-se independentemente da presença do educador erudito. Ele pode participar aportando, com o seu conhecimento, informações e interpretações que, a partir dos seus problemas colocados pelas e nas situações de trabalho popular, explicitam e fortalecem o saber popular. (Brandão, 2006, p.52)

O PVNC - Vila Operária, através de seus professores militantes, provoca o debate e o questionamento do ensino aplicado nas escolas formais. Discute-se, por exemplo, se o ensino oferecido a estes alunos, oriundos de escolas públicas, condiz com a realidade dos vestibulares. A partir daí, espera-se o posicionamento crítico desses alunos em suas escolas formais em relação ao conteúdo trabalhado, pois caso eles percebam uma defasagem educacional, possam questionar um ensino que contemple a realidade dos vestibulares.

As práticas da educação popular representam desde já a vontade de criar espaços autônomos, espaços nos quais o manejo do poder se realize em forma compartida, dentro de uma crescente relação entre iguais. Nesta perspectiva as opções metodológicas adquirem relevância especial... A busca de formas educativas de caráter participativo, de reflexão coletiva da prática dos próprios atores, do desenvolvimento de relações de solidariedade entre os membros, a superação dos dogmatismos e preconceitos etc., constituem opções-chave neste sentido. (La Educación Popular Hoy en Chile: Elementos para Definiria, p. 13)

A dimensão desses posicionamentos dos alunos nos espaços formais acaba gerando para o PVNC uma organização política de seus alunos "militantes" perante aos gestores de suas escolas formais. Ao lidar com os conflitos e negociações, em que muitas vezes terão que recuar e em outras vezes avançar na sua luta política, os alunos do PVNC aprendem a se posicionar de maneira cidadã no diálogo entre discente e docente, buscando 
assim uma reflexão sobre o conteúdo apresentado e o conteúdo cobrado nos exames de vestibulares.

É importante salientar que o PVNC tem em seus militantes (professores e coordenadores) as experiências vivenciadas em seu passado, como opressão e negação dos direitos a educação pública de qualidade, pois muitas escolas públicas estaduais e municipais em sua história tiveram um abandono em sua estrutura seja ela como espaço físico, ou como capital humano. Como consequência, estudantes oriundos de classes populares tornaram-se um grande "refém" de uma educação abandonada pelos gestores públicos, já que, ao terminarem o ensino médio, percebem que o conteúdo didático apresentado em sua trajetória escolar é um conteúdo defasado.

Essas experiências fazem com que o PVNC em suas aulas de "Cultura e Cidadania" procure trabalhar com seus alunos, leituras críticas sobre o porquê deste descaso com a educação pública do Brasil. Por meio dessas leituras, idealiza-se um aluno que possa ser um agente transformador deste processo histórico e que ainda possa compreender as políticas educacionais oferecidas pelo setor do público.

Segundo Paulo Freire, em seu livro Educação e Mudança:

\begin{abstract}
Compromisso com o mundo, que deve ser humanizado para a humanização dos homens, responsabilidade com estes, com a história, que implica uma responsabilidade histórica, não pode realizar-se através do palavrório, nem de nenhuma outra forma de fuga do mundo, da realidade concreta, onde se encontram os homens concretos. O compromisso, próprio da existência humana, só existe no engajamento com a realidade, de cujas "águas" os homens verdadeiramente comprometidos ficam "molhados", ensopados. Somente assim o compromisso é verdadeiro. (Freire, 1997, p. 18-19)
\end{abstract}

É neste sentido que o PVNC, ao longo de sua história, acredita no compromisso da educação popular como agente transformador da luta pela educação de base. O PVNC, como educação popular, tem em suas raízes as obras do educador Paulo Freire, citadas frequentemente nos debates das aulas de "Cultura e Cidadania".

Em seu livro Pedagogia do Oprimido, ele afirma que:

Quem, melhor que os oprimidos, se encontrará para entender o significado terrível de uma sociedade opressora? Quem sentirá, melhor que eles, os efeitos da pressão? Quem, mais que eles, para ir compreendendo a necessidade da libertação? Libertação a que não chegaram pelo acaso, mais pela práxis de sua busca; pelo conhecimento e reconhecimento da necessidade de luta por ela. (Freire, 1987, p.31) 
São nessas indagações que o núcleo Vila Operária busca o entendimento para o fortalecimento de suas aulas de "Cultura e cidadania". Os pré-vestibulares comunitários reconhecem o significado de uma sociedade opressora, pois os mesmos lutam incansavelmente contra o sistema. Principalmente dentro das próprias universidades quando na década de 1990 os movimentos de educação popular começaram a se destacar e arranhar a estrutura elitista das universidades com a chegada considerável de alunos carentes nesses espaços até então conhecidos e ocupados pelas elites brasileiras. De acordo com Brandão, o saber de classes subalternas favorece o crescimento democrático de educação, como pode-se verificar na citação a seguir:

\footnotetext{
Um saber da comunidade torna-se o saber das frações (classes, grupos, povos, tribos) subalternas da sociedade desigual. Em primeiro longínquo sentido, as formas - imersas ou não em outras práticas sociais, através das quais o saber das classes populares ou das comunidades sem classes é transferido entre grupos ou pessoas, são a sua educação popular. (Brandão, 2006, p.26)
}

Utilizar o conhecimento da comunidade como base para o ensinamento é uma forma que o PVNC - Vila Operária tem de construir uma educação popular comprometida e participativa. Buscar compreender a comunidade e seus anseios a partir de sua própria realidade para, em seguida, fornecer meios para o seu aprendizado.

Quem melhor que esses alunos desprovidos economicamente e oriundos de um sistema de educação defasado para enfrentar as situações conflitantes com os grandes "donos dos saberes". Ainda hoje, é comum creditar a decadência de algumas áreas ou departamentos por conta da população carente que ocupa o espaço dentro das universidades.

É neste momento que percebemos a diferença dos alunos que chegam às universidades públicas e às particulares (com bolsa) em seu posicionamento em relação a esta política de não aceitação, pois a disciplina "Cultura e Cidadania" procura preparar seus alunos militantes para os conflitos de negação de sua existência. Esses alunos não devem abrir mão de princípios que balizam seus interesses e, a partir desse embate, elaborar estratégias de resistências contra a política de um não reconhecimento deste no espaço acadêmico.

Somente a partir desses embates políticos que esses alunos se sentirão libertos da opressão, pois somente reconhecendo os seus direitos é que eles se sentem libertos. 


\begin{abstract}
A libertação, por isto, é um parto. É um parto doloroso. O homem que nasce deste parto é um homem novo que só é viável na e pela superação da contradição opressores - oprimidos que é a libertação de todos. A superação da contradição é o parto que trás ao mundo este homem novo não mais opressor; não mais oprimido, mas homem libertando-se... (Freire, 1987, p.35)
\end{abstract}

Enfim, O movimento de educação popular, pelo qual o PVNC faz parte, procura vincular conhecimento popular e conhecimento científico, onde um não anula o outro, porém eles se complementam, pois esse saber popular encontrase fora das grades curriculares das escolas e das universidades. Esses saberes populares se encontram principalmente nas visitas ou trabalhos de campo em comunidades tradicionais (quilombolas, indígenas), Movimentos dos trabalhadores Rurais Sem Terra (MST), palestras dentro dos próprios prévestibulares comunitários, onde não se exige grau de formação dos palestrantes, mais sim, a sua história de vida para que possam fortalecer o respeito e a valorização daqueles que de certa maneira contribuíram e vem contribuindo para história da educação popular no Brasil.

\title{
1.3. \\ PVNC núcleo Vila Operária e educação popular: um caso específico
}

O núcleo Vila Operária procura trabalhar o processo de aprovação nos vestibulares através de uma consciência coletiva em que não basta passar no vestibular, mas que é necessário cortar as "cercas" do abismo existente entre aquela população desfavorecida que ao longo dos anos lhes foram negado o ensino público de qualidade, e tentar aproximar a universidade do "mundo real" daqueles em que grande maioria da população que termina o ensino médio não consegue ter acesso ao "mundo não real" (universidades).

Isso só se faz possível, porque o projeto de educação popular é uma combinação entre a luta pelo acesso a universidade e uma consciência coletiva crítica. Neste caminhar procura fazer campanhas de discussão sobre a população negra marginalizada que durante décadas the foi negado o direito básico e humano que se chama educação, pois sabemos que a melhor maneira de valorizar o conhecimento e a história de um povo é lidando o princípio básico dos direitos humanos, que é a educação.

O núcleo PVNC tem sido uma figura muito importante na formação cidadã dos jovens que por lá passam, mesmo aqueles que não conseguem chegar à universidade percebem $\mathrm{o}$ quanto foi importante viver no ambiente tão 
enriquecedor no que tange a formação de um ser mais crítico e mais reflexivo em relação aos seus direitos e os direitos coletivos e a valorização da cultura. $A$ citação de Caldart, a seguir, reflete a militância que o PVNC - Vila Operária buscou construir em sua base pedagógica.

A dinâmica da luta social é acelerada demais para manter nela quem se alimenta apenas de palavras ou de idéias sem raiz. Mesmo onde não esteja explícita como princípio pedagógico, a relação entre teoria e prática é uma exigência da própria condição de ser antes sem terra e depois estudante. (Caldart, 2000, p.211)

São nessas experiências que o núcleo Vila Operária se espelhará para formar militantes políticos que saibam se posicionar seja nas universidades ou não, mas sempre como agente transformador e multiplicador dos ideários da militância.

\section{4.}

O PVNC da Vila Operária em Nova Iguaçu - A formação de estudantes-trabalhadores para a inserção nas Universidades

No caso do PVNC - Vila Operária, os professores podem ser indicados por coordenadores, professores que participam ou já participaram do projeto, alunos, ex-alunos, comunidade. Posteriormente os docentes eram convidados a conhecer o movimento, sua dinâmica para, quem sabe, colaborar com o crescimento ideológico da educação popular realizada no município de Nova Iguaçu. Além disso, havia inúmeras reuniões, onde esses futuros militantes tinham a possibilidade de participar do debate de forma ativa.

O PVNC (núcleo Vila Operária) não tem o voluntariado em sua estrutura de formação política, e sim o militante, já que a militância exige "espírito de sacrifício, capacidade de organização, clareza ideológica e solidariedade (PAIVA, Irene)". São esses 4 pontos citados por Paiva que o Núcleo - Vila Operária se baseia nas suas práticas de luta.

Desse modo, o militante do PVNC (núcleo Vila Operária) acredita numa transformação societária a partir da educação popular, seja ela educacional, política ou social, pois militar é reconhecer uma luta constante de inserção. No caso do PVNC, a luta é de alunos que ao longo da história de suas vidas tiveram o direito negado a um ensino de qualidade que lhes proporcionasse "condições de igualdade" com aqueles que sempre tiveram ensino de qualidade. O militante do PVNC tem em sua consciência política que enquanto existir um estudante 
necessitando de um apoio educacional cidadão é porque a luta ainda não está vencida, por isso, ele será considerado um militante.

Uma das principais características do PVNC, que unificou a prática dos núcleos, era a implantação de algumas atividades pré-definidas como, por exemplo, a disciplina cultura e cidadania. Para Emerson, essa disciplina era fundamental porque:

\begin{abstract}
Os pré-vestibulares passam a se caracterizar também como um movimento alicerçado sobre pactos ideológicos frouxos, o que lhes coloca diante de um paradoxo: tais pactos ideológicos, de um lado, têm alto poder de reprodutibilidade [...] E tais rupturas se dão tanto no plano individual, o que se manifesta, por exemplo, na alta rotatividade de professores em boa parte dos núcleos, quanto no plano coletivo do que no abandono do corte racial nos nomes de cursos que se desvincularam da rede é apenas um indicativo de um conjunto de resistência a assunção real (e não formal) de bandeiras ideológicas fundadoras do movimento. Essas resistências se consubstanciam, sobre tudo na execução de um trabalho com pouco peso relativo para a disciplina cultura e cidadania [...] Diante disso, a criação de uma disciplina específica com este fim, ou, de um momento privilegiado para garantir tais discussões, fez de cultura e cidadania o elo de convergência entre a preparação do vestibular, a conscientização política e a busca de uma proposta pedagógica adequada a realidade e aos interesses dos segmentos sociais envolvidos no PVNC... (Santos, 2003, p.233- 234)
\end{abstract}

A disciplina "Cultura e Cidadania" está voltada para uma discussão ampliada sobre racismo, direitos sociais e se apoia principalmente nos fundamentos dos direitos humanos. Como se nota, o PVNC, como movimento de educação popular, não se restringe ao aprendizado de conteúdos específicos transmitidos por técnicas para a aprovação no vestibular. O movimento visa uma discussão mais profunda em relação ao conteúdo apresentado, procura debater com seus alunos a relação do conteúdo aprendizado para que os mesmos possam compreender a importância da disciplina apresentada. Ao longo dos anos, cursos pré-vestibulares comunitários (PVNC) procuram transmitir aos discentes que passar no vestibular é uma consequência do trabalho apresentado e não uma mera concorrência entre cursos e colegas de sala, porque mais que passar no vestibular é compreender a base da história da educação brasileira.

O PVNC tem em seus militantes (professores e coordenadores) as próprias experiências vivenciadas em seu passado, como opressão e negação dos direitos à educação pública de qualidade, pois as escolas públicas estaduais e municipais em sua história tiveram um abandono em sua estrutura seja ela como espaço físico, seja como capital humano. Os alunos ao terminarem o ensino médio percebem que o conteúdo didático apresentado em toda sua vida escolar é um conteúdo defasado, o que os colocam em sua maioria apenas para 
o trabalho secundário. ${ }^{4}$ Desse modo, os estudantes oriundos de classes populares são um grande "refém" de uma educação abandonada pelos gestores públicos.

Essas experiências fazem com que o PVNC em suas aulas de cultura e cidadania procure trabalhar com seus alunos, leituras críticas sobre o porquê deste descaso com a educação pública do Brasil. E através dessas leituras idealizarem no aluno que ele possa ser um agente transformador deste processo histórico e ainda compreender a quem interessa este ensino.

Segundo Paulo Freire, em seu livro "Educação e Mudança":

Compromisso com o mundo, que deve ser humanizado para a humanização dos homens, responsabilidade com estes, com a história, que implica uma responsabilidade histórica, não pode realizar-se através do palavrório, nem de nenhuma outra forma de fuga do mundo, da realidade concreta, onde se encontram os homens concretos. O compromisso, próprio da existência humana, só existe no engajamento com a realidade, de cujas "águas" os homens verdadeiramente comprometidos ficam "molhados", ensopados. Somente assim o compromisso é verdadeiro. (Freire, 1997, p. 18-19)

É neste compromisso que o PVNC nestes 20 anos de história acredita na educação popular como agente transformador da luta pela educação de base. Desta forma, a proposta pedagógica do PVNC se inspira nas obras do educador Paulo Freire, muito utilizadas nos debates das discussões das aulas de cultura e cidadania.

Em seu livro Pedagogia do Oprimido, ele afirma que:

Quem, melhor que os oprimidos, se encontrará para entender o significado terrível de uma sociedade opressora? Quem sentirá, melhor que eles, os efeitos da pressão? Quem, mais que eles, para ir compreendendo a necessidade da libertação? Libertação a que não chegaram pelo acaso, mais pela práxis de sua busca; pelo conhecimento e reconhecimento da necessidade de luta por ela. (Freire, 1997, p. 31)

São nessas indagações, propostas por Paulo Freire, que o núcleo Vila Operária busca o entendimento para o fortalecimento de suas aulas de cultura e cidadania. Os pré-vestibulares comunitários reconhecem o significado de uma sociedade opressora, já que lutam incansavelmente contra o sistema opressor,

\footnotetext{
${ }^{4}$ Setor Secundário É o setor da economia que transforma as matérias-primas (produzidas pelo setor primário) em produtos industrializados (roupas, máquinas, automóveis, alimentos industrializados, eletrônicos, casas, etc). Como há conhecimentos tecnológicos agregados aos produtos do setor secundário, o lucro obtido na comercialização é significativo. Países com bom grau de desenvolvimento possuem uma significativa base econômica concentrada no setor secundário. A exportação destes produtos também gera riquezas para as indústrias destes países. (SILVA, José, L. Conceição, 1999).
} 
principalmente, dentro das próprias universidades a partir da década de 1990. Nessa época, os movimentos de educação popular começaram a se destacar e arranhar a estrutura elitista das universidades com a chegada em massa de alunos das classes populares ou das classes trabalhadoras nesses espaços até então conhecidos e ocupados pelas elites brasileiras.

Quem melhor que esses alunos desprovidos de uma situação econômica estável e de um sistema de educação defasado para encarar as situações conflitantes com os "donos dos saberes" que negam a existência desses alunos nas universidades e, em muitas vezes, em suas disciplinas. Acredita-se que esses alunos de classes populares colaborariam para a decadência, ou melhor, para descredibilização de seus departamentos.

É neste momento que percebemos a diferença dos alunos que chegam às universidades públicas e particulares com bolsa, já que se posicionam contra esta política de rejeição das classes trabalhadoras nos bancos universitários, pois são preparados pela disciplina "cultura e cidadania" para os conflitos de negação de sua existência. Esses alunos não devem abrir mão de princípios que balizam seus interesses e elaborar estratégias de resistências contra a política de um não reconhecimento deste no espaço acadêmico.

Somente a partir desses embates políticos que esses alunos, oriundos de uma política de inclusão, sentir-se-ão libertos da opressão, pois ao reconhecer os seus direitos, sentem-se libertos.

A libertação das amarras só é possível através de uma educação revolucionária e que esta educação revolucionária em muitas das vezes não vêm das universidades nem dos bancos das escolas, ela se faz nos movimentos de educação popular, buscando a luta política nas bases de uma sociedade. Dando aos alunos uma organização de como lidar com o poder das falas e ideias para que estes possam abandonar o pensamento de oprimido e possam levar para as escolas e universidades uma educação libertadora e articulação entre o saber popular $^{5}$ e o científico. ${ }^{6}$

O movimento de educação popular, do qual o PVNC faz parte, procura vincular conhecimento popular e conhecimento científico, onde um não anula o outro, porém eles se complementam, pois esse saber popular encontra-se fora

\footnotetext{
${ }^{5} \mathrm{O}$ senso comum (saber popular) é reflexivo, valorativo, com base em estados de ânimo e emoções; os valores do sujeito afetam a análise do objeto. Este não possui uma sistematização de ideias, a qual poderia ser usada para o entendimento que explique os fenômenos observados (CARVALHO, T. M. de. p.230, 2009).

${ }^{6} \mathrm{O}$ conhecimento científico distingue-se de outras formas de conhecimento através da utilização de normas empíricas, argumentos lógicos, ceticismo, e da forma como os cientistas se esforçam para obterem as melhores e possíveis explicações sobre o mundo natural (CARVALHO, T. M. de. p.230, 2009).
} 
das grades curriculares das escolas e das universidades. Reconhecer a sua história de vida é fundamental para que possam fortalecer o respeito e a valorização daqueles que de certa maneira contribuíram e vem contribuindo para história da educação popular.

Sendo assim, o PVNC de Vila Operária tendo como base em seu quadro de fundadores militantes adeptos a luta pela terra, trazem para o núcleo um processo enriquecedor da pedagogia do Movimento dos Trabalhadores rurais Sem Terra (MST), procurando pôr em prática os ensinamentos pedagógicos do MST para a realidade do PVNC (núcleo Vila Operária).

\begin{abstract}
Aprendemos que o processo de formação humana vivenciado pela coletividade sem terra em luta é a grande matriz para pensar uma educação centrada no desenvolvimento do ser humano, preocupada com a formação de sujeitos da transformação social e da luta permanente por dignidade, justiça, felicidade. (Construindo o Caminho - MST. p.125, 2001)
\end{abstract}

O núcleo procura trabalhar o processo de aprovação nos vestibulares através de uma consciência coletiva em que não basta passar no vestibular, mas que é necessário cortar as "cercas" do abismo existente entre a população desfavorecida que ao longo dos anos Ihes foram negado o ensino público de qualidade, e tentar aproximar a universidade do "mundo real" daqueles em que grande maioria da população que termina o ensino médio não consegue ter acesso às universidades.

Isso só se faz possível porque o projeto de educação popular é uma combinação entre a luta pelo acesso a universidade e uma consciência coletiva crítica. O núcleo tem sido uma instância muito importante na formação cidadã dos jovens e mesmo aqueles que não conseguem chegar à universidade percebem o quanto foi importante viver no ambiente tão enriquecedor no que tange a formação de um ser mais crítico e mais reflexivo em relação aos seus direitos e os direitos coletivos e a valorização da cultura.

A dinâmica da luta social é acelerada demais para manter nela quem se alimenta apenas de palavras ou de idéias sem raiz. Mesmo onde não esteja explícita como princípio pedagógico, a relação entre teoria e prática é uma exigência da própria condição de ser antes sem terra e depois estudante... (Caldart, 2000, p.211)

Baseado nessas experiências que o núcleo Vila Operária se espelhará para formar militantes políticos que saibam se posicionar seja nas universidades ou não como agente transformador e multiplicador dos ideários da militância. 


\section{5 .}

\section{As ações afirmativas - Uma política voltada para grupos que vivem em condições de desigualdade social}

Entende-se como ação afirmativa medidas pontuais que surgem em determinadas sociedades com o objetivo de reparar uma determinada situação histórica de discriminação. Segundo Barbosa (2003), as ações afirmativas podem ser definidas como um conjunto de políticas públicas e privadas de caráter compulsório, facultativo ou voluntário, concebidas com vistas ao combate à discriminação racial, de gênero, por deficiência física e de origem nacional, bem como para corrigir ou mitigar os efeitos presentes da discriminação praticada no passado, tendo por objetivo a concretização do ideal de efetiva igualdade de acesso a bens fundamentais como a educação e o emprego.

No caso do PVNC - Vila Operária, a reparação está voltada para a inclusão do negro marginalizado nas universidades, uma vez que estes sempre encontraram dificuldades de serem inseridos como alunos comuns no ensino superior.

No Brasil, as políticas de ações afirmativas é fruto de reivindicações das populações marginalizadas e desfavorecidas de todas as políticas públicas e sociais. De acordo com Nascimento:

\footnotetext{
Foi na década de 1990 que, de fato a sociedade, as instituições de governo, do legislativo e do judiciário, as escolas e universidades, a mídia, as empresas e outros entes estatais e privados passaram a discutir mais profundamente o racismo, o preconceito, a discriminação, a desigualdade racial e políticas contra esses problemas. (Nascimento, 1999, p.146)
}

Isso só foi possível devido à lei 7.716/89 onde seu art. $1^{\circ}$ "Serão punidos, na forma desta Lei, os crimes resultantes de discriminação ou preconceito de raça, cor, etnia, religião ou procedência nacional. (Redação dada pela Lei no 9.459, de 15/05/97)", fazendo com que o movimento negro pudesse reivindicar os direitos a educação, ao reparo histórico, a discussão mais profunda sobre a desigualdade racial e social lutando por reconhecimento de igualdade para com os ditos "brancos". E ainda exigindo do Estado uma política de reconhecimento de uma desigualdade histórica que precisa ser combatida, e que para serem combatidos os negros precisam ter uma visibilidade na sociedade brasileira.

A igualdade só poderá ser alcançada através de uma política que possa reduzir as diferenças entre negros e brancos ao longo da história. As lutas sociais foram importantíssimas para que em 2003 fosse criado um órgão com 
contribuição específica de criar políticas para promoção de igualdade racial, o (CNPIR) Conselho Nacional de Promoção da Igualdade Racial. E ainda obtivemos um ganho neste período com a criação da lei 10.639/2003, que se trata da obrigatoriedade do ensino da história da África e da cultura afrobrasileira.

Entre várias conquistas no campo da igualdade racial e social, a ação do PVNC merece especial destaque no campo da educação superior.

Em 1993 foi criado o primeiro núcleo do PVNC (no município de São João de Meriti) discutiam-se políticas de acesso de alunos de escolas públicas e negros nas universidades públicas e privadas com bolsa de $100 \%$ sem saber que estava colaborando para o avanço das ações afirmativas no Brasil. O PVNC fundamenta-se em sua "Carta de Princípios" na seguinte citação:

No conceito Ação Afirmativa como ação coletiva de afirmação de identidade e luta por relações econômicas, políticas, sociais e culturais democráticas. Trata-se de uma concepção de Ação Afirmativa que vai além da instituição de políticas públicas direcionadas a um determinado grupo social. (Carta de Princípios, p.6)

O movimento PVNC teve como uma das Universidades parceiras a Pontifícia Universidade Católica do Rio de Janeiro (PUC-RJ), que mesmo antes de se discutir políticas de ações afirmativas e permanência, já adotava o sistema de ação afirmativa. Em 1994, recebeu os primeiros alunos pobres (desprovidos economicamente) oriundos do PVNC em sua instituição com bolsas sociais de $100 \%$ nos cursos de graduação e além das bolsas discutiam-se os primeiros passos, o campo de permanência para esses alunos oriundos do movimento. Até então, por mais políticas que o movimento vinha fazendo para entrada de alunos nas universidades ainda não se discutia de fato políticas de ações afirmativas, com ênfase em cotas para universidades.

O movimento durante toda a década de 1990 lutou firmemente por mais abertura de vagas nas universidades, por cursos noturnos, vestibulares na baixada fluminense até então concentradas na cidade do Rio e Niterói, ocupações e debates para o surgimento de novos campus das universidades publicas, como por exemplo, UFF em Nova Iguaçu, por mudanças de grades curriculares que pudessem atender a esse alunos e por alojamentos. 
Ações afirmativas podem ser compreendidas como ações públicas ou privadas, ou ainda programas que buscam promover oportunidades ou outros benefícios para pessoas pertencentes a grupos específicos, alvo de discriminação. Tais ações têm como objetivo garantir o acesso a recursos, visando remediar uma situação de desigualdade socialmente indesejável. (IBASE, 2008 p.29)

Os debates sobre as ações afirmativas não chegavam com tanta suavidade aos núcleos do PVNC, já que para alguns a discussão referente à cota racial gerava um desconforto, pois não se entendia exatamente o que era política de ações afirmativas e muito menos cotas raciais. As discussões em relação às ações afirmativas ficaram mais nas universidades ou na imprensa conservadora que procurava alimentar que as cotas eram para favorecer os negros que não tinham capacidade de passar no vestibular. Leva-se um tempo para que esses debates possam ser efetivamente entendidos e compreendidos por alguns militantes do PVNC para que, a partir de então, possam de fato amadurecer e reconhecer e estudar e debater: o que são políticas de ações afirmativas?

O PVNC - Vila Operária - passa a ter um amadurecimento sobre ações afirmativas e sua importância quanto política de reconhecimento racial a partir dos embates nas assembleias e nos conselhos que se consolidaram na década de 2000.

As aulas de "Cultura e Cidadania" ministradas no núcleo também fortaleciam a política de reconhecimento das diferenças socioeconômicas, políticas e raciais. Os debates sobre esses temas estavam na "Carta de Princípios", como podemos observar:

Os debates de CULTURA E CIDADANIA devem se desenvolver sobre questões como: Racismo, Discriminação, Preconceito, Gênero, Cultura, ideologia, Cidadania, Democracia, Políticas Públicas. Violência, Direitos Constitucionais, Civis e Trabalhistas, Movimentos Sociais, Conjuntura Política e Econômica, Neoliberalismo. Globalização ou temas sugeridos no interior do núcleo através de um planejamento participativo, tendo a mesma carga horária semanal das outras disciplinas. Sua construção pedagógica é diferente das demais disciplinas, pois é aberta para que o conjunto construa uma visão de si, dos outros e da sociedade, numa dinâmica que engloba: Palestras, Debates. Análises de Filmes, Músicas e Textos, Peças teatrais, Dinâmicas de Grupos etc. Esta matéria não deve ter um único professor, devendo ser desenvolvida pelas coordenações do núcleo através de convites a pessoas especializadas nos vários assuntos específicos. (Carta de Princípios. p.13)

Esses debates contribuem para que de fato a sociedade possa reconhecer a situação em que se encontra uma parte significativa da população negra no Brasil. O núcleo - Vila Operária - procura estabelecer discussões e debates 
sobre a marginalização em que se encontram os afrodescendentes brasileiros para que os seus alunados tenham uma consciência de luta inclusiva em todos os segmentos da sociedade. 


\section{2 \\ O Pré-Vestibular Vila Operária - A sua gênese e formação}

A presente pesquisa se propõe a conhecer como se deu a formação do PVNC - Vila Operária, localizado no município de Nova Iguaçu. Para isto buscou-se inicialmente identificar os principais articuladores e organizadores do PVNC. Ao iniciarmos uma conversa com os atuais membros deste núcleo, alguns nomes foram destacados: Sr. Salvador Marcelino, Sra. Laurita Ferraz, Sra. Lourdes dos Santos, Ramofly Bicalho, Altair Lisboa, Alexandre Lino e Alzivane Barreira.

Segundo o trabalho de campo feito por meio das entrevistas, pode-se identificar que o Sr. Salvador foi o principal articulador político e responsável pela articulação entre o Pré- Rancho Novo e Frei Davi (fundador do primeiro núcleo PVNC em São João de Meriti). Já a Sra. Laurita era responsável pelo direcionamento estrutural da formação do Pré-vestibular e incentivadora do movimento social na comunidade. Além disso, era na residência de Laurita onde aconteciam as reuniões chamadas de "grupo de estudo" que posteriormente tornou-se o Pré-Vestibular - Rancho Novo.

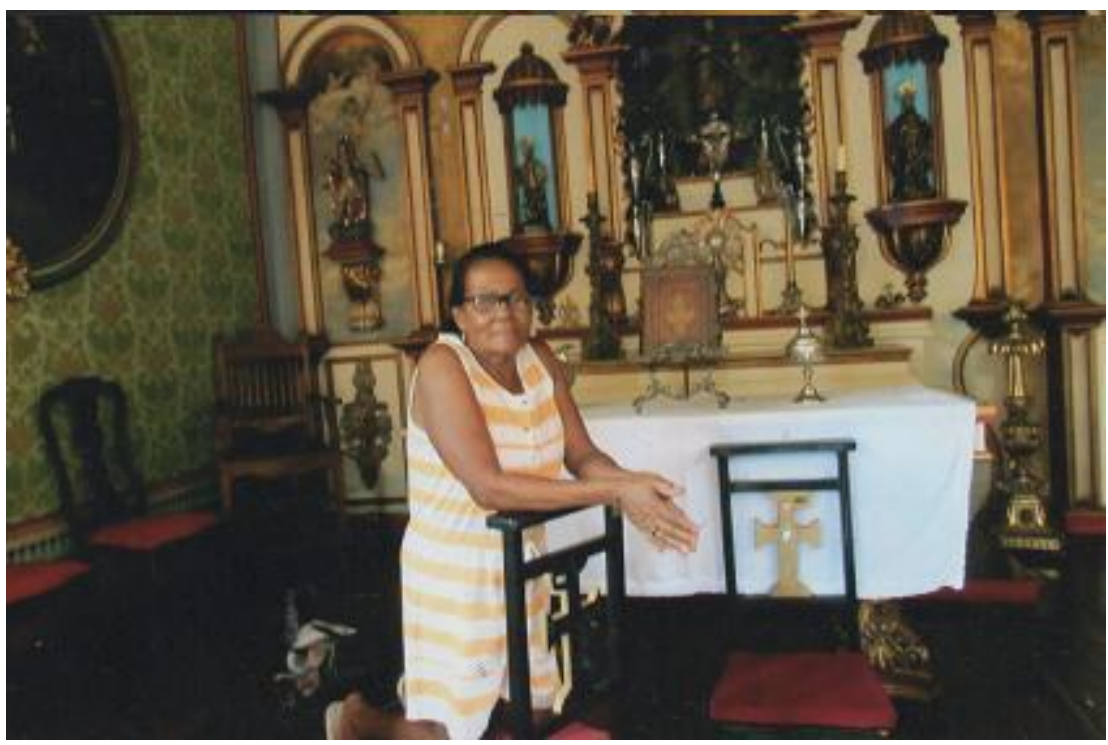

Figura 1- Laurita Ferraz: uma das protagonistas do Núcleo - Rancho Novo.

Dona Lourdes foi a responsável por ceder o espaço físico definitivo de funcionamento do PVNC - Vila Operária. Ainda hoje é diretora da Escola que se mantém como colaborador do PVNC. Por fim, Ramofly, Altair, Alexandre e 
Alzivane eram professores do Pré, além disso, os dois primeiros desempenhavam o papel de coordenadores.

As entrevistas foram realizadas no período de 3 meses, de novembro de 2014 a fevereiro de 2015. Em visita à residência dos entrevistados, realizamos algumas perguntas já pré-estabelecidas e, por meio de um gravador de voz, registramos as respostas. No entanto, como foi uma entrevista semi-estruturada, pudemos colher informações afins além do que eram esperadas, contribuindo para o enriquecimento dessa pesquisa.

Com as informações obtidas, começamos a detalhar a gênese de formação do PVNC- Vila Operária. De acordo com o professor Ramofly, o PVNC - Rancho Novo começa a ser desenhado em 1994, quando um de seus fundadores foi proibido de frequentar aulas num pré-vestibular privado, localizado no município de Nova Iguaçu, por estar atrasado com a mensalidade. A partir desse episódio, outros dois estudantes indignados com a forma com que o amigo foi tratado, abandonaram o curso e de forma solidária resolveram criar um grupo de estudo para prestar o vestibular, mas não obtiveram êxito em seus objetivos. Passado esse momento, em 1995, os 3 estudantes continuaram com o grupo de estudo e no final do ano, um aluno conseguiu ser aprovado no vestibular da UERJ no curso de geografia.

$\mathrm{Na}$ metade dos anos 90 , quando a política privatizante passou de fato a afetar a economia brasileira, notou-se um empobrecimento da população. Com isso, as universidades privadas tiveram uma redução de procura em seus vestibulares, enquanto as públicas tiveram uma procura ascendente, como podemos verificar na citação a seguir:

\begin{abstract}
A despeito de o incremento da matrícula, na década de 90 , ter sido bem mais expressivo que aquele verificado nos anos 80 , manteve-se em níveis medíocres no período 1990/1993. Somente a partir de 1994 é que se define uma tendência de crescimento contínuo, com taxas anuais acima de $4 \%$. A demanda, medida pelo total de inscrições nos exames vestibulares, cresceu cerca de $76 \%$ entre o início e o final do período compreendido por este estudo. Apesar de a oferta de vagas terem sido ampliadas em níveis relativamente baixos ao longo da primeira metade da década de 90, acelerou-se a partir de 1997. Desse modo, o crescimento da oferta foi ligeiramente maior que o da demanda, implicando, assim, pequena redução da relação candidatos/vaga. No que se refere à demanda, identificam-se duas tendências distintas. Entre as instituições públicas, cresce significativamente o número de candidatos por vaga oferecida, ao passo que, na esfera privada, ocorre o inverso. (Corbocci, 2001, p.105)
\end{abstract}

Como se percebe, o número de matriculados até 1993 ainda era muito discreto nas universidades públicas. O crescimento de procura torna-se significativo ao mesmo tempo em que os movimentos de educação popular 
passam também a ter uma importância na conjuntura política-educacional brasileira. Coincidência ou não, o ano de ascensão dos pré-vestibulares PVNC é o ano em que a procura pelas universidades públicas se elevam. Merece um destaque especial o sentimento de satisfação vivido pelos primeiros alunos que ingressaram nas universidades do R.J, como se pode ver pelas imagens da reportagem a seguir:

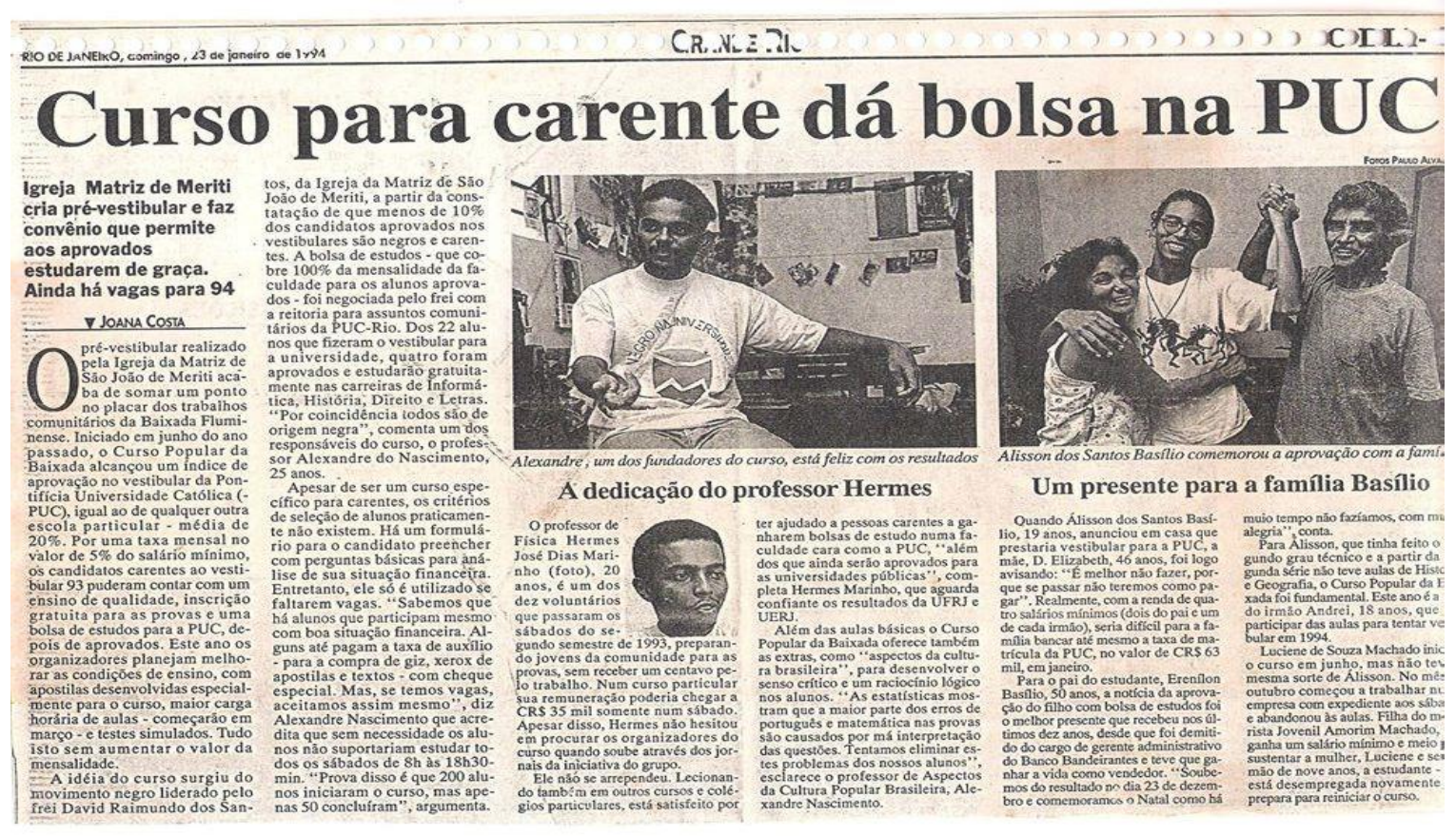

Figura 2 - Em 1994, os movimentos sociais começam a ganhar destaque, elevando o número de alunos carentes nas universidades.

Em 1996, com o ingresso de um dos companheiros de discussão do Pré Núcleo Vila Operária para a universidade, apenas um membro começa a pensar em montar um grupo de estudo maior, porém ainda não com o objetivo de se formar um pré-vestibular. A lógica era pensar a conjuntura política, econômica e social do momento, discutindo por meio de reuniões realizadas mensalmente. Com o passar do tempo, outros companheiros começaram a se aproximar e pensar em inserir alunos da comunidade nas universidades. Mas para isso, o grupo precisava ter uma base teórica política para saber para onde ir e contra quem lutar. Foram feitas rodadas e mais rodadas de discussões, entre elas o que é o socialismo, o que é o comunismo, o que é uma sociedade igualitária para ter de fato um grupo de estudo que pudesse não só inserir alunos nas universidades, mas também formar cidadãos com uma consciência revolucionária daquele momento que se enfrentava. Para situar, os anos 90 passavam por uma forte instabilidade política e econômica que afetou uma boa 
parte dos operariados que se refletiu em seus familiares.

Depois dos anos 80 , a "década perdida", parecia que nada poderia ser pior. No entanto, o desempenho econômico da década de 1990 não somente foi a metade do ocorrido nos anos 80 como foi o pior do século, e com ele se esvanece o sonho de uma melhor distribuição de renda e de uma sociedade mais justa [...] O Estado nacional foi desmontado a golpes de privatizações lesivas, de sonegações e guerras fiscais e de sucessivos cortes de gastos e despesas públicas. O desemprego atinge em cada cinco habitantes das grandes cidades. A informalidade atinge outros dois a cada cinco. A pobreza alcança níveis até hoje desconhecidos. (Mattoso, 2000, p. 21-22)

Um grupo de jovens que possuía uma afinidade política, partidária e religiosa, já que uns pertenciam ou eram simpatizantes dos ideais difundidos pelo Partido dos Trabalhadores e outros eram membros da Igreja Católica, reuniam-se então em prol de alternativas a fim de refletir toda essa conjuntura política e econômica que o Brasil estava enfrentando nos anos 90.

Segundo o professor Altair, num primeiro momento, a igreja católica, que naquele ano pensava em relação à construção de um movimento social, e os partidários do PT influenciaram muito na trajetória de formação do que se tornaria o Pré-Vestibular - Rancho Novo. Durante todo o ano de 1996, esse grupo amadureceu, através dos estudos e das lideranças políticas locais, a ideia de formar um pré-vestibular que atendesse à comunidade do seu entorno. Nesse mesmo ano, o grupo então põe em votação o surgimento do pré-vestibular. Aprovada a ideia, começava a busca por um local com uma estrutura apropriada que abrigasse nossos futuros alunos.

Sugerido o espaço que era do Colégio Estadual Vereador Percy Crispim, houve uma pesquisa de campo relacionada à mobilidade dos estudantes e dos professores e o resultado foi bem positivo, já que a localização favorecia a comunidade. Após esse levantamento, o próximo passo foi visitar a diretora da unidade escolar e apresentar o projeto, mostrando a sua importância não só para a comunidade, mas também para própria escola, tendo em vista que favoreceria os próprios alunos da escola. Outros dois encontros com a diretora foram feitos até que ela aceitasse ceder o espaço. 


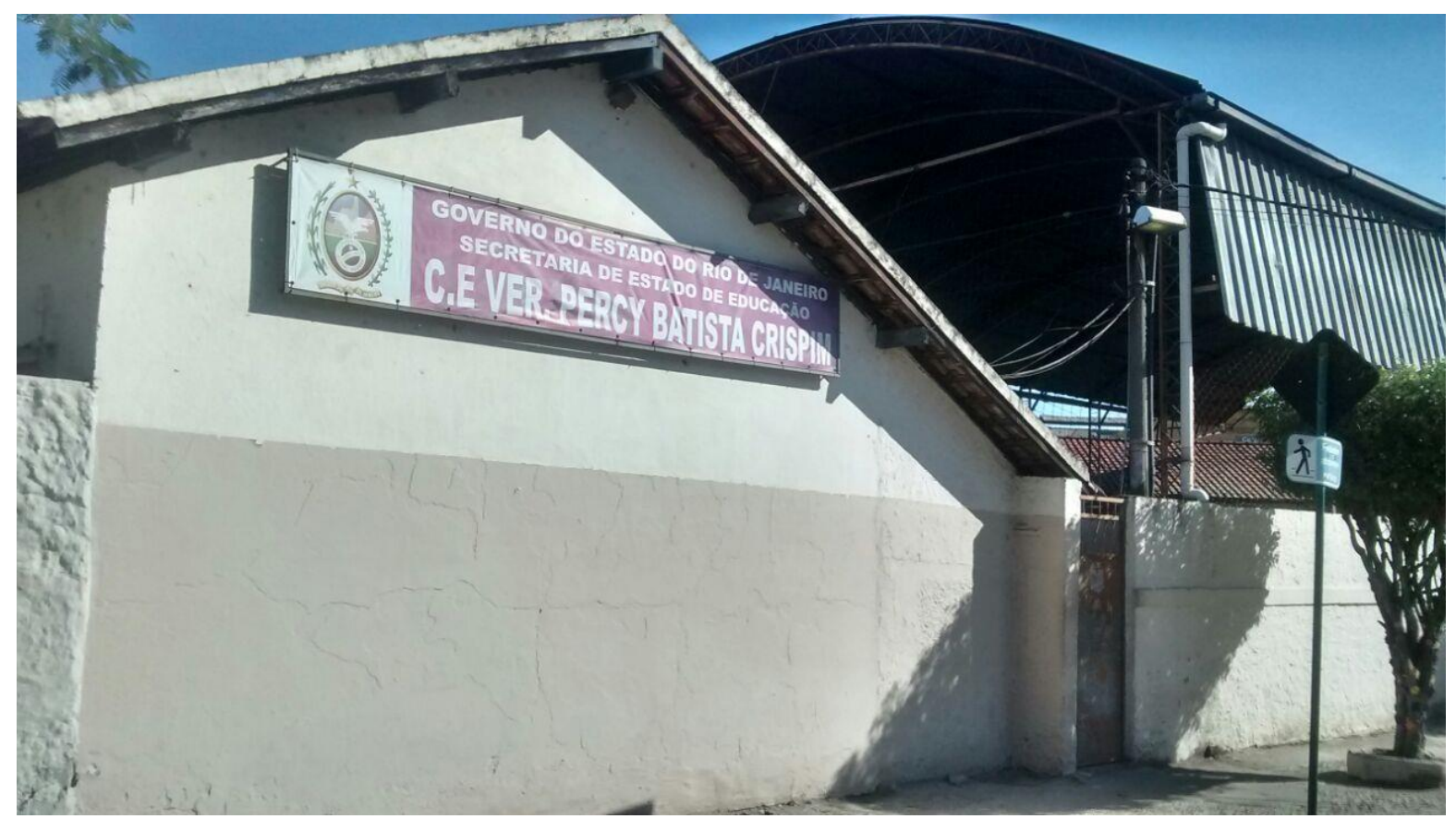

Figura 3- Colégio Estadual Vereador Percy Batista Crispin: local das realizações das aulas do núcleo Rancho Novo.

Com isso, em fevereiro de 1997, o Pré-Vestibular - Rancho Novo - inicia-se suas atividades no Colégio Estadual Vereador Percy Batista Crispim. Nesse primeiro ano, os coordenadores e professores se surpreenderam com a grande procura, por parte dos alunos, pelo curso de pré-vestibular. Quase 100 alunos, a maioria da comunidade, interessaram-se pelo pré-comunitário, o que proporcionou uma corrida em busca de novos companheiros para lecionar, pois naquele momento havia apenas 6 professores disponíveis.

Para o professor Alexandre, o primeiro ano do Pré foi muito difícil em termos de conseguir novos militantes para a causa, pois era necessário passar a consciência da luta, ou seja, inserir alunos nas universidades públicas e privadas (com bolsas) e formá-los para os embates que poderiam enfrentar em relação à sua origem econômica, social e racial. Por este motivo, precisou-se trabalhar, dentro de nossas aulas, a teoria e prática de cultura e cidadania. Essa prática também era passada para os novos professores afim de que eles compreendessem a filosofia do grupo, já que muitos que vieram para contribuir a desconheciam. No entanto, alguns militantes não compreendiam que a aula de cultura e cidadania era uma bandeira essencial para a formação de nossos alunados. Para alguns, o conteúdo programático era mais importante, porque "Cultura e Cidadania” não era cobrado nos vestibulares. Em contrapartida para o PVNC - Vila Operária: 
A construção diária do trabalho pedagógico requer dos professores uma metodologia em que a teoria e a prática se expressam sob a unidade de ensinoaprendizagem, o que implica priorizar a sua historicidade, a compreensão do seu conteúdo como parte de uma totalidade empírica e teórica, a sua dialética entre a identificação de sua materialidade concreta e sua potencialidade transformadora. (Rosar, 2014, p.99)

Segundo os fundadores do projeto, mesmo com essa divergência, a filosofia do Pré conseguiu se sobressair em virtude da formação dos 6 companheiros que ficaram durante um ano, rascunhando o que hoje se tornaria o Pré-Vestibular Comunitário. E com seguidas reuniões, a ideia das aulas de "Cultura e Cidadania" foi entendida e compreendida pelos professores que iniciavam sua militância no Pré.

A coordenação era composta por 3 membros (eu, Ramofly, Altair) que tinham a responsabilidade de organizar os horários, as disciplinas, a divulgação do cronograma dos vestibulares, divulgação do pré-vestibular, matrícula de alunos, a receita, a prestação de conta e manutenção do espaço utilizado, ou seja, toda parte pedagógica e administrativa estava a cargo da coordenação. Além disso, cabia à coordenação dialogar com a direção da unidade escolar onde o Pré se instalou.

O professor Alzivane lembra que no primeiro ano de funcionamento, o PréVestibular foi surpreendido com a primeira aprovação, em menos de 6 meses, de um dos alunos no vestibular de inverno da PUC-RJ. Porém este aluno ainda não vinculado ao PVNC, o Núcleo entrou em contato com o PVNC - Núcleo Heliópolis - para que este aluno fosse acolhido, já que o Rancho Novo estava no período de transição de comunitário para PVNC. Como o PVNC - Núcleo Heliópolis- acolheu nossa aluna (Cláudia), ela pôde ser contemplada com uma bolsa de estudo $100 \%$ para o curso de história.

Com a aprovação da aluna, o curso ganhou um ânimo a mais para seguir com a sua militância. Em agosto de 1997, o curso passou a ser PVNC - Rancho Novo - fruto de vários diálogos entre seu Salvador, Altair e Frei Davi. O assento só foi concedido após assembleia geral dos núcleos PVNC, em Duque de Caxias, onde ficaram definidos novos núcleos, entre eles, o PVNC - Rancho Novo.

$\mathrm{Na}$ sociedade das redes (para usar uma terminologia de Manuel Castells), o associativismo localizado (ONGs comunitárias locais) ou setorizado (ONGs feministas, ecologistas, étnicas, e outras) ou, ainda, os movimentos sociais de base locais (de moradores, sem teto, sem terra, etc.) percebem cada vez mais a necessidade de se articularem com outros grupos com a mesma identidade social ou política, a fim de ganhar visibilidade, produzir impacto na esfera pública e obter 
conquistas para a cidadania. (Scherer-Warren, 2006, p.113)

A partir desse momento, a participação nas assembleias, nos conselhos, nas tomadas de decisões em relação ao andamento do movimento PVNC foi mais efetiva. Tudo isso se refletia dentro do núcleo - Rancho Novo e um novo rumo foi definido, tendo como base a "Carta de Princípio" do PVNC. O núcleo Rancho Novo - deixa de ser puramente comunitário, isolado, e passa a ser um curso Pré Vestibular para Negros e Carentes. Desse modo, uma nova identidade é assumida, mas não perdendo a sua essência filosófica de militância, adquirida durante os encontros antes da formação do pré-vestibular.

Aparentemente cada movimento tem seus problemas, sua identidade, suas bandeiras, seus interesses e seus desafios específicos, que precisam ser enfrentados. Mas, se estas lutas se circunscreverem à particularidade de cada indivíduo ou categoria em torno de seus desafios, elas no máximo possibilitam resolver os problemas particulares. Contudo, se cada um fizer o mesmo, se fechar em si e querer resolver apenas seus problemas, não será possível enfrentar problemas substanciais, comuns a todos. Esses têm a sua solução, não na particularidade, mas no enfrentamento comum, e demandam unidade de luta. (Orso, 2014, p. 193)

Ao passar a ser um curso PVNC, o núcleo- Rancho Novo - passou agora de uma forma direta a indicar alunos para serem contemplados, após aprovação no vestibular, com uma carta de recomendação para a reitoria comunitária da PUC-Rio. O conteúdo dessa carta visava certificar que aquele candidato se enquadrava nas condições de aluno carente para concorrer a bolsas de estudo, 100 \%, da Pontifícia Universidade Católica do Rio de Janeiro - PUC-RJ ou de outras universidades públicas. Praticamente, todos os alunos indicados foram contemplados com a bolsa integral da PUC em diversos cursos da graduação. Mas para que isso acontecesse, a coordenação e os alunos tinham que estar sempre presentes nas assembleias e alguns membros do núcleo, nos conselhos. 

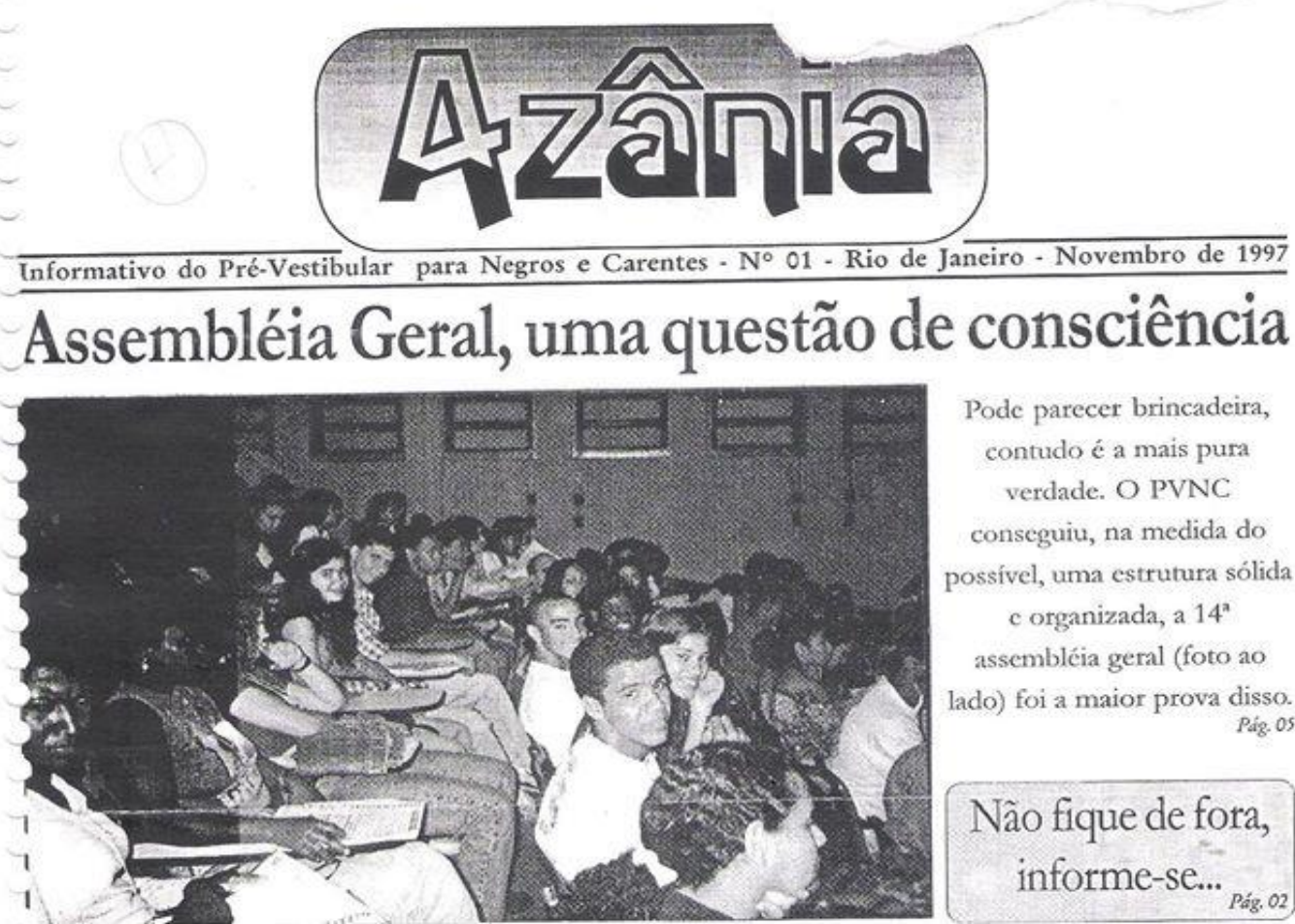

Pode parecer brincadeira, contudo é a mais pura verdade. O PVNC

conseguiu, na medida do possível, uma estrutura sólida c organizada, a $14^{\text {a }}$ assembléia geral (foto ao lado) foi a maior prova disso.

Não fique de fora, informe-se..

PVNC faz campanha pela Fiducação Aprovado na $14^{a}$ assembléia geral em Niterói, a campanha em favor da educação pública e de qualidade tem envolvido vários alunos, professores e coordenadores do PVNC.

Pág. O4

Tem estudado bastante?

Teste seus conhecimentos de história e geografia com o AZÂNIA.

\section{De quem é a culpa?}

Sebastião Salgado, famoso fotógrafo brasileiro, fala sobre o trágico acidente que matou Lady Di.

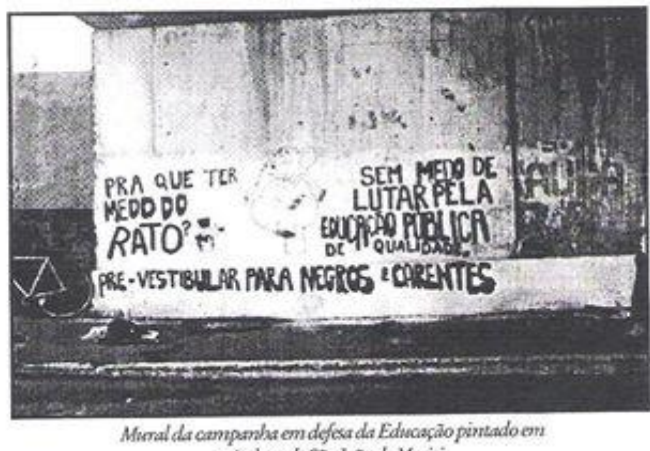
viaduto de Síojazade Meriti

Figura 4 - As assembleias eram frequentemente noticiadas nos jornais internos dos PVNC,s.

No final do primeiro ano de 1997, o PVNC - Rancho Novo teve uma boa aprovação nos vestibulares do Rio de Janeiro (UERJ, UFRJ, UFF, UNIRIO, UFRRJ, PUC- Rio). Mais uma vez, o resultado obtido foi surpreendente, já que grande parte dos professores não era formada e os alunos, oriundos de escolas públicas, demonstravam uma defasagem em termos de conteúdo acadêmico. No 
ano seguinte, alguns desses aprovados passaram a contribuir diretamente com o andamento do projeto. Começava nesse momento, a consciência da importância do pré-vestibular para aqueles que tiveram a oportunidade de passar no vestibular, via educação popular.

Tudo parecia caminhar bem, no entanto, em 1999, o Pré-Vestibular foi surpreendido com uma decisão da direção que a partir daquele momento não seria mais cedido o espaço da escola para as aulas do curso. Não houve diálogo com a direção, apenas um bilhete colado no portão, avisando a decisão. O professor Sérgio Roberto até hoje ativista do PVNC-Vila Operária e na época era aluno do Pré conta como foi esse dia:

"Era $1^{\circ}$ de maio de 1999, tudo parecia normal, mesmo sendo um feriado nacional. A programação era estudar e para isso eu caminhava até o Colégio Estadual Percy Batista Crispim, onde funcionava o PVNC - Rancho Novo. Mas a normalidade do dia termina ao chegar no colégio, as portas estavam fechadas, sem nenhuma explicação. Logo a preocupação começou a tomar conta, pois não tinha condições de arcar com as despesas de um pré-vestibular privado. Um dos coordenadores precisava ir até a PUC-RIO, pois desenvolvia um projeto e não podia deixar de comparecer. Mesmo com o compromisso, esse coordenador não nos deixou desamparados e junto com o professor Alexandre organizou uma aula numa praça que ficava próximo ao colégio. Tivemos aula ali, embaixo de sol, alguns dispersaram, mas a maioria ficou. Quando o coordenador retornou, depois de algumas horas, ficamos sabendo que o Colégio Seis de Janeiro, que ficava no bairro Vila Operária, tinha cedido espaço para que o projeto continuasse. Como o colégio era de educação infantil, não contava com estrutura para atender aqueles 100 alunos, aproximadamente. Eram poucas carteiras disponíveis, com isso alguns alunos chegaram a sentar no chão ou em tapetes que lá estavam. Decorrido o susto, era preciso se organizar ou o projeto poderia acabar ali. O coordenador, junto com outros companheiros, conseguiu doações de carteiras e quadros em algumas universidades, entre elas UFRRJ e PUC-RIO. Aquele dia ficou marcado, pois percebi quantas pessoas poderiam ser prejudicadas por um ato da diretora do Colégio Estadual Percy Batista Crispim, mas com o apoio de pessoas que acreditavam no projeto tudo foi revertido e pude continuar estudando a aprender coisas que são importantes até hoje". 


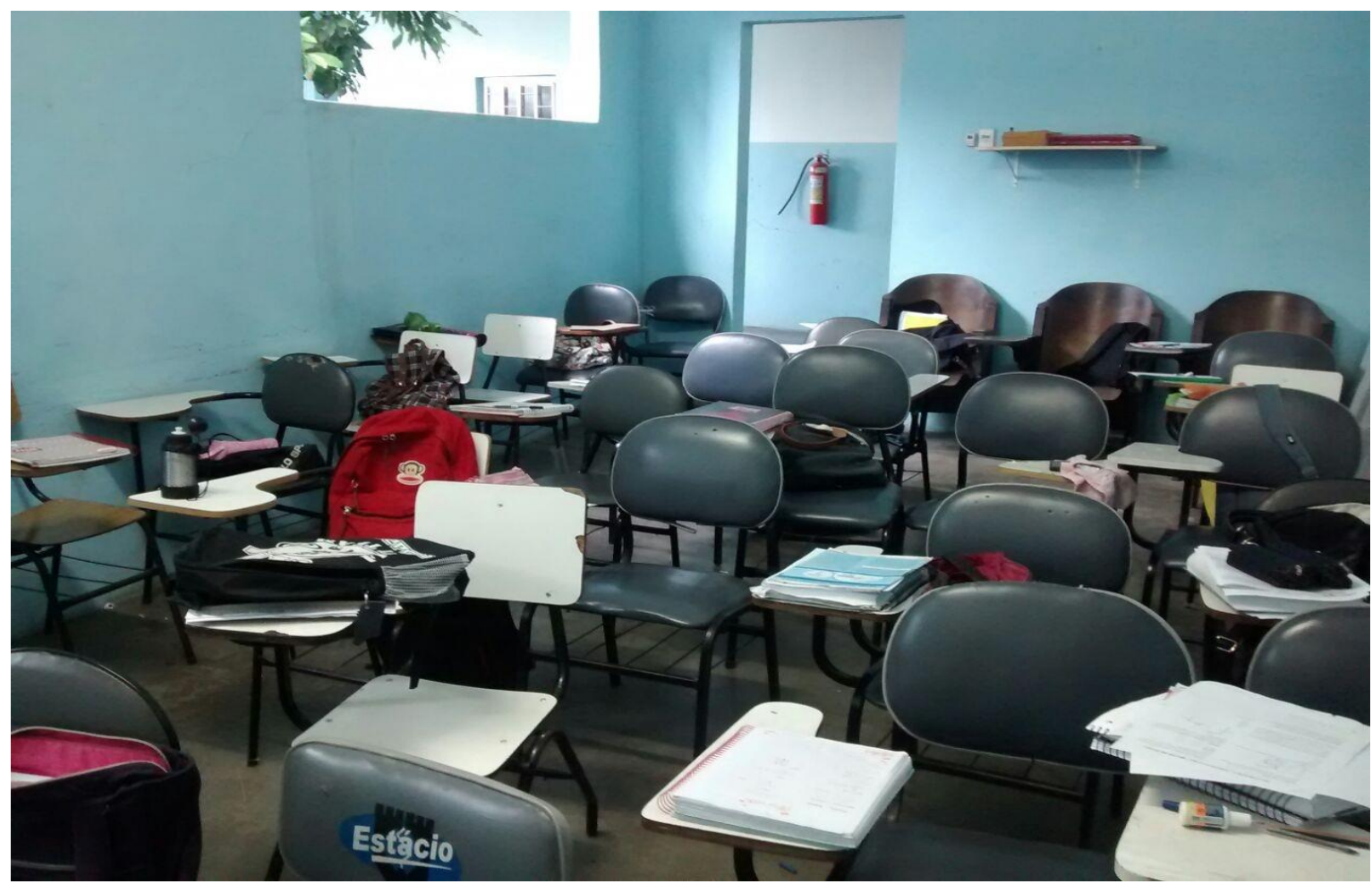

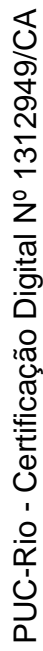

Figura 5- Uma das salas do PVNC - Vila Operária: Ao fundo ainda há 3 carteiras doadas pela UFRRJ.

Seu Salvador Marcelino, uns dos protagonistas da formação política de alguns membros da coordenação, considera que esse momento foi histórico para todos os envolvidos, porque percebeu que toda a política que ele e tia Laurita tinham desenvolvido foi posta em prática, pois o grupo não se abalou com o fechamento da escola e deu aula embaixo da amendoeira durante dois dias até conseguir espaço em outra escola.

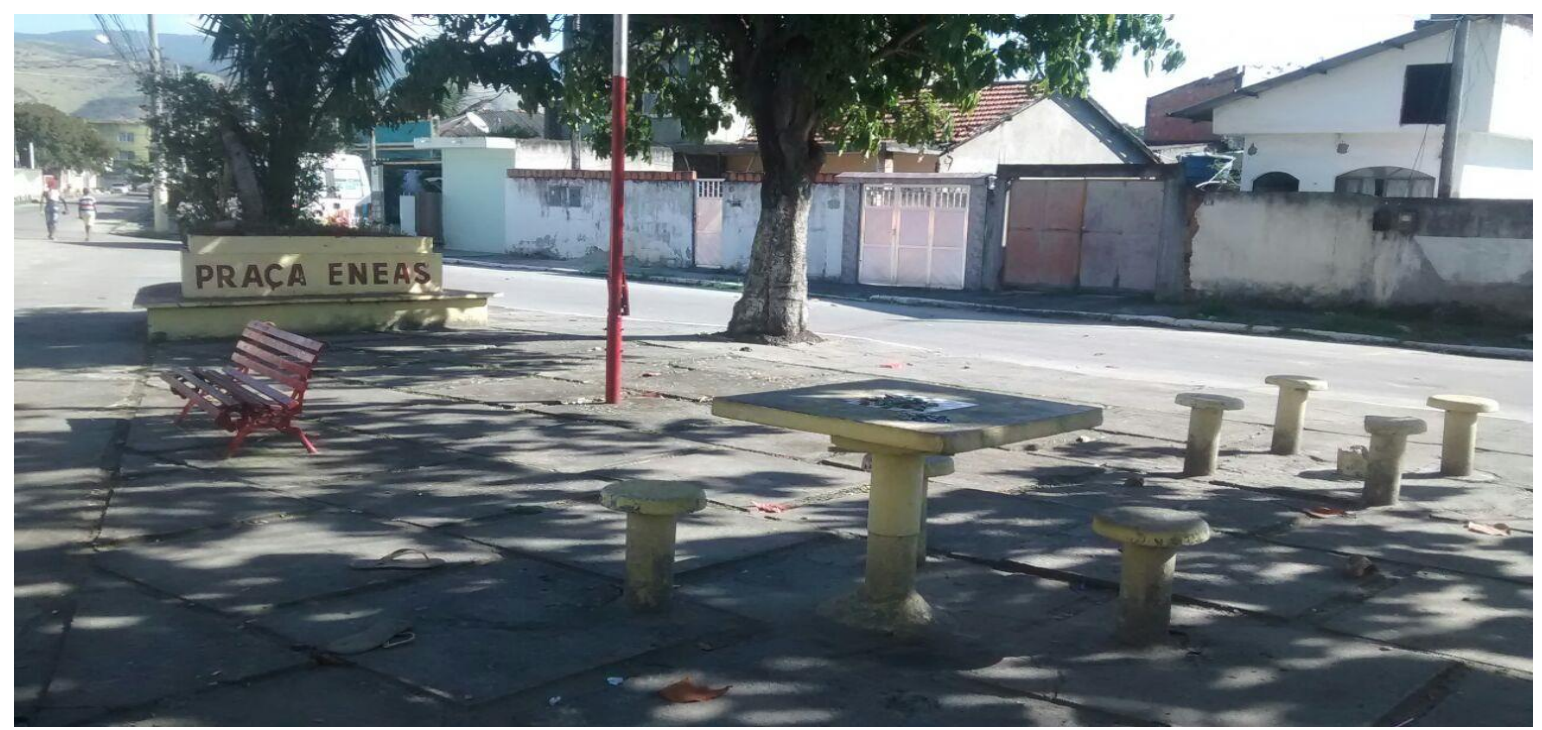

Figura 6- Praça Eneas: local da aula do dia 1ํ de maio de 1999. 
A diretora do Colégio Seis de Janeiro, Lourdes dos Santos, em depoimento conta como foi esse momento e todo o impacto causado com a entrada do PVNC em sua escola e na comunidade.

Em 1999, quando os alunos do Pré-Vestibular foram expulsos do Colégio Estadual Vereador Percy Batista Crispim, que se localizava no bairro Rancho Novo, vieram parar no meu espaço (Colégio Seis de Janeiro), no bairro Vila Operária, onde eu os acolhi. Quando eles chegaram, não havia cadeiras para todos, pois eram mais ou menos 90 alunos no meu espaço.

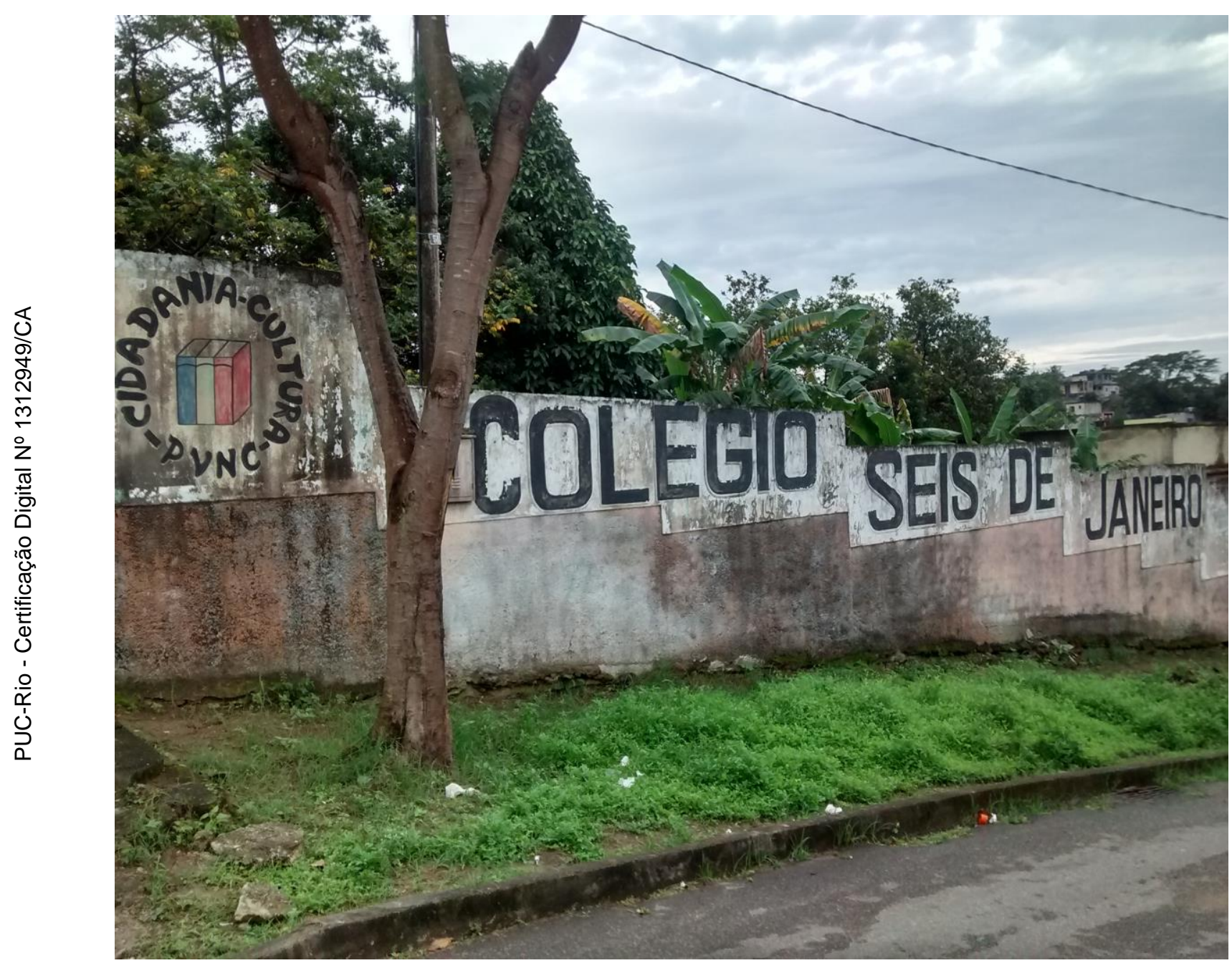

Figura 7- Parte externa do Colégio Seis de Janeiro.

A partir daí, passei a conhecer o projeto PVNC, em que meu filho e coordenador do curso, Renato, fazia parte, pois até então não tinha noção da importância do projeto e o impacto que ele viria causar à comunidade de Vila Operária.

Então, abracei o projeto em meu espaço e isso trouxe muitos benefícios para a minha escola, dentre eles, as cadeiras, pois, como falei, não tínhamos 
para todos. A coordenação do Pré conseguiu doações com a UFRRJ e com a PUC-RIO de cadeiras para os alunos. A partir da entrada do PVNC, o Colégio Seis de Janeiro passou a ser mais conhecido na comunidade, onde a referência era o Pré-Vestibular, pois o meu colégio somente oferecia educação infantil e ensino fundamental ( $1^{\circ}$ ao $5^{\circ}$ ano). Lourdes dos Santos Diretora do Colégio Seis de Janeiro.

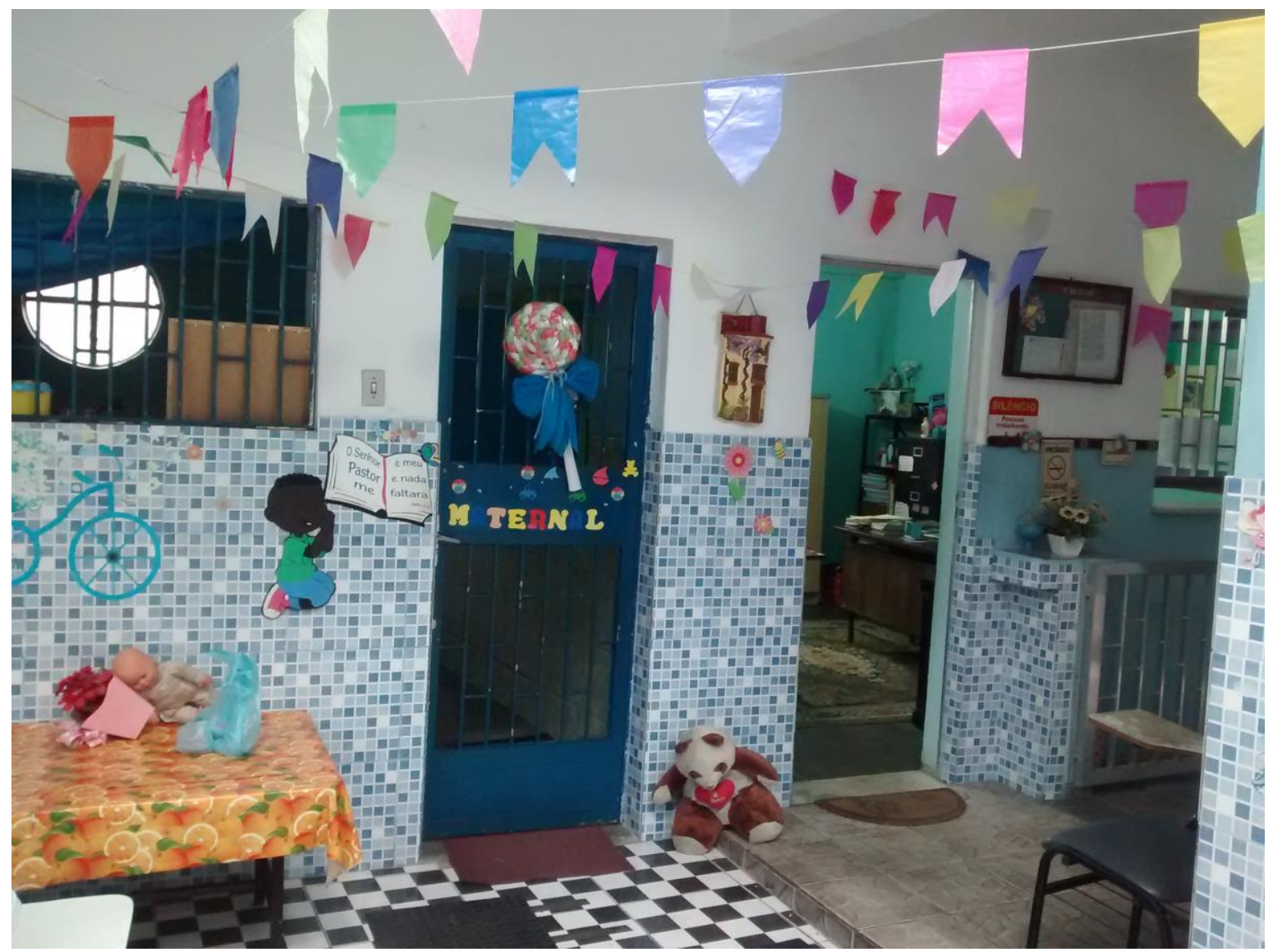

Figura 8- Parte interna do Colégio Seis de Janeiro.

Ainda no que se refere à integração entre escola e PVNC, a Sra. Lourdes ressaltou em seu depoimento que os alunos do PVNC interagiram muito bem com o Seis de Janeiro, onde a quadrilha de festa junina do pré-vestibular passou a ser a atração principal na escola. Tudo isso ajudava na divulgação da escola perante a comunidade. Por meio desses eventos, era possível mostrar um pouco da atividade escolar, o que ajudava na formação de novas turmas. Umas das atividades desenvolvidas na Escola e que demonstrava a força da parceria estabelecida entre escola e PVNC foi a "Festa caipira". 


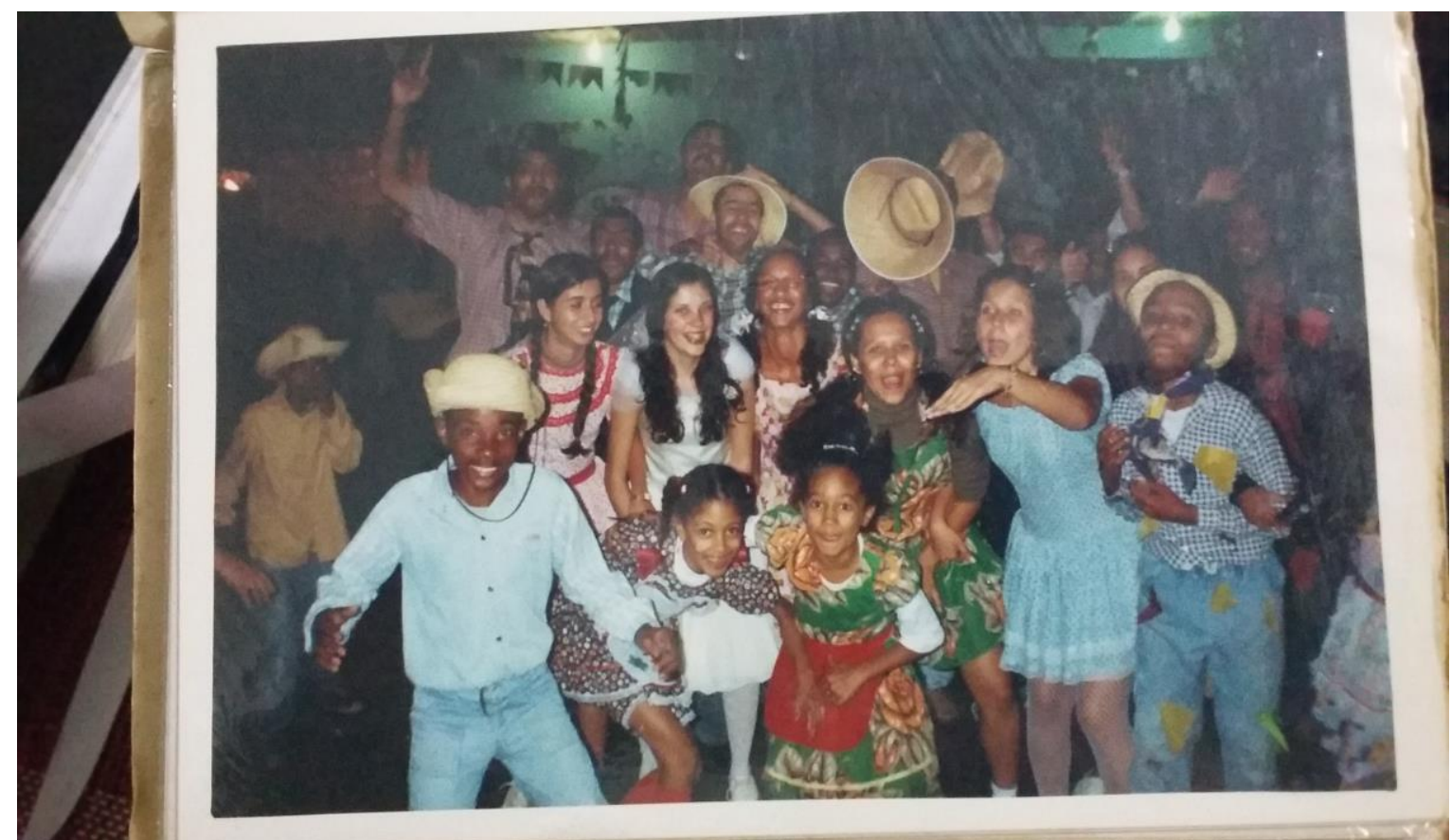

Figura 9- Festa Junina do Colégio Seis de Janeiro: interação entre alunos do PVNC e a escola.

Ainda segundo a Sra. Lourdes, o pré-vestibular durante 10 anos (20002010) realizou no meu espaço o "Baile dos Calouros", onde toda a comunidade Vila Operária participava para prestigiar os alunos que foram aprovados no vestibular. O baile acontecia uma vez ao ano, à noite toda, onde alunos e comunidade e depois ex-alunos se confraternizavam. Também era comum nesse baile, professores serem homenageados por alguma conquista (pós-graduação, mestrado, doutorado, concurso público).

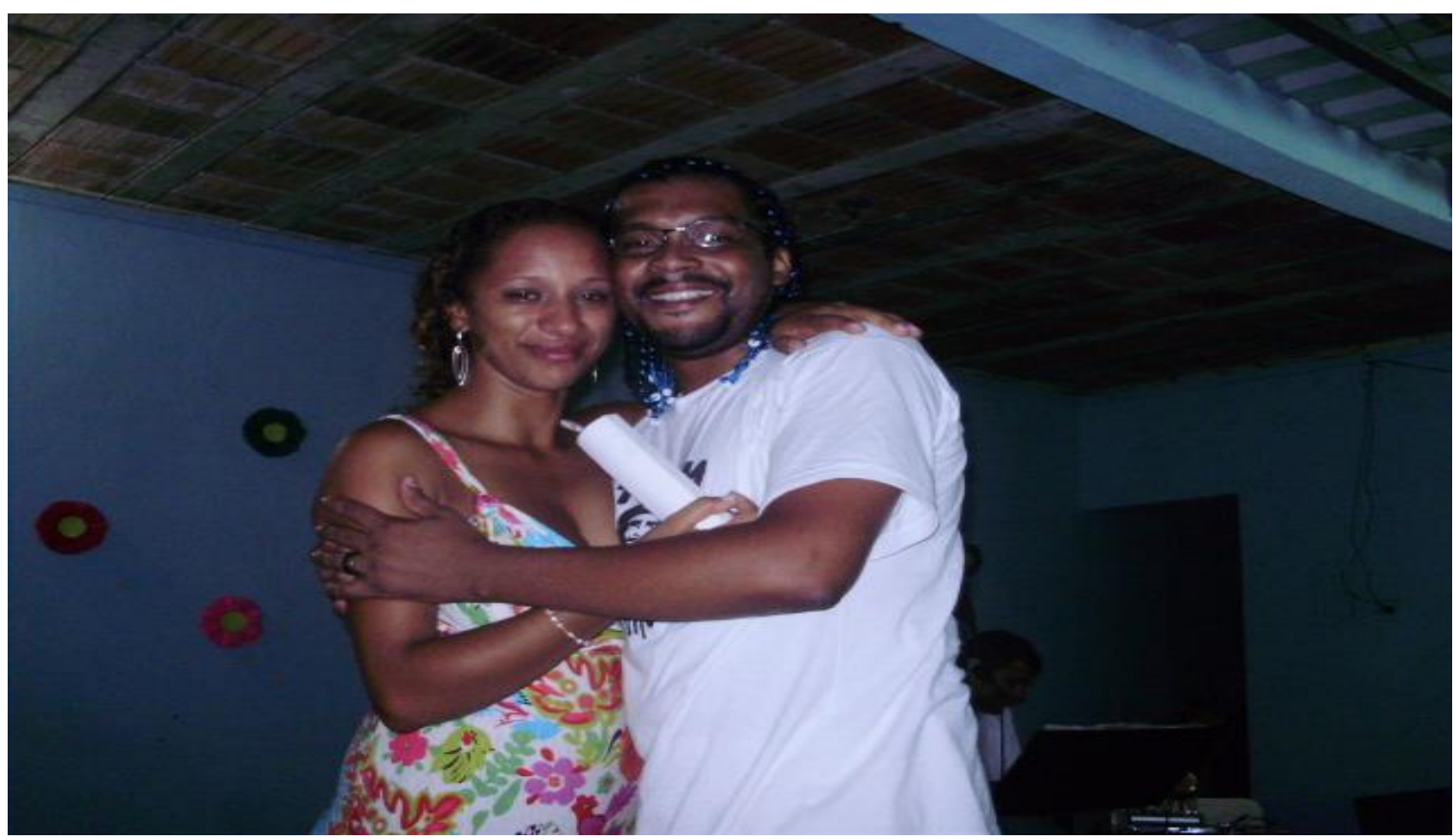

Figura 10- Professora Letícia: homenagem pelo seu ingresso no Doutorado. 
Com isso, o Seis de Janeiro, através do pré-vestibular, ficou bem reconhecido na comunidade e nas proximidades e depois até em outros municípios do Rio de Janeiro. Tivemos, por exemplo, alunos de Bangu, Santa Teresa, Queimados, Niterói, lugares considerados longe em relação à localização do curso, que conseguiram aprovação e estão bem sucedidos no mercado de trabalho.

Os anos se passaram e em 2006, conseguimos implantar no Colégio o EJA (Educação para jovens e adultos) para o ensino médio, a pedido da comunidade, devido às aprovações que tínhamos para o vestibular.

Segundo Joaquim Barbosa (2003), um dos principais objetivos das Políticas de Ação Afirmativa é a formação de "personalidades emblemáticas" que seria a possibilidade de criação de "exemplos de mobilidade ascendente". Quer dizer, "os representantes da minoria" que, por terem alcançado posições de prestígio e poder, serviriam de exemplo às gerações mais jovens, que veriam em suas carreiras e realizações pessoais a sinalização de que não haveria chegada a sua vez, obstáculos intransponíveis à realização de seus sonhos.

Um exemplo de "mobilidade ascendente" ocorreu com a própria Dona Lourdes que, por causa do projeto "llustres e anônimos", virou umas das celebridades negra no município de Nova Iguaçu, tendo a sua foto em exposição no teatro do município. Renato também foi reconhecido como uma celebridade de Nova Iguaçu e também teve sua foto exposta no evento. Este trabalho foi realizado pelo fotógrafo Paulo Santos, reconhecido no município de Nova Iguaçu por apresentar personalidades negras. 


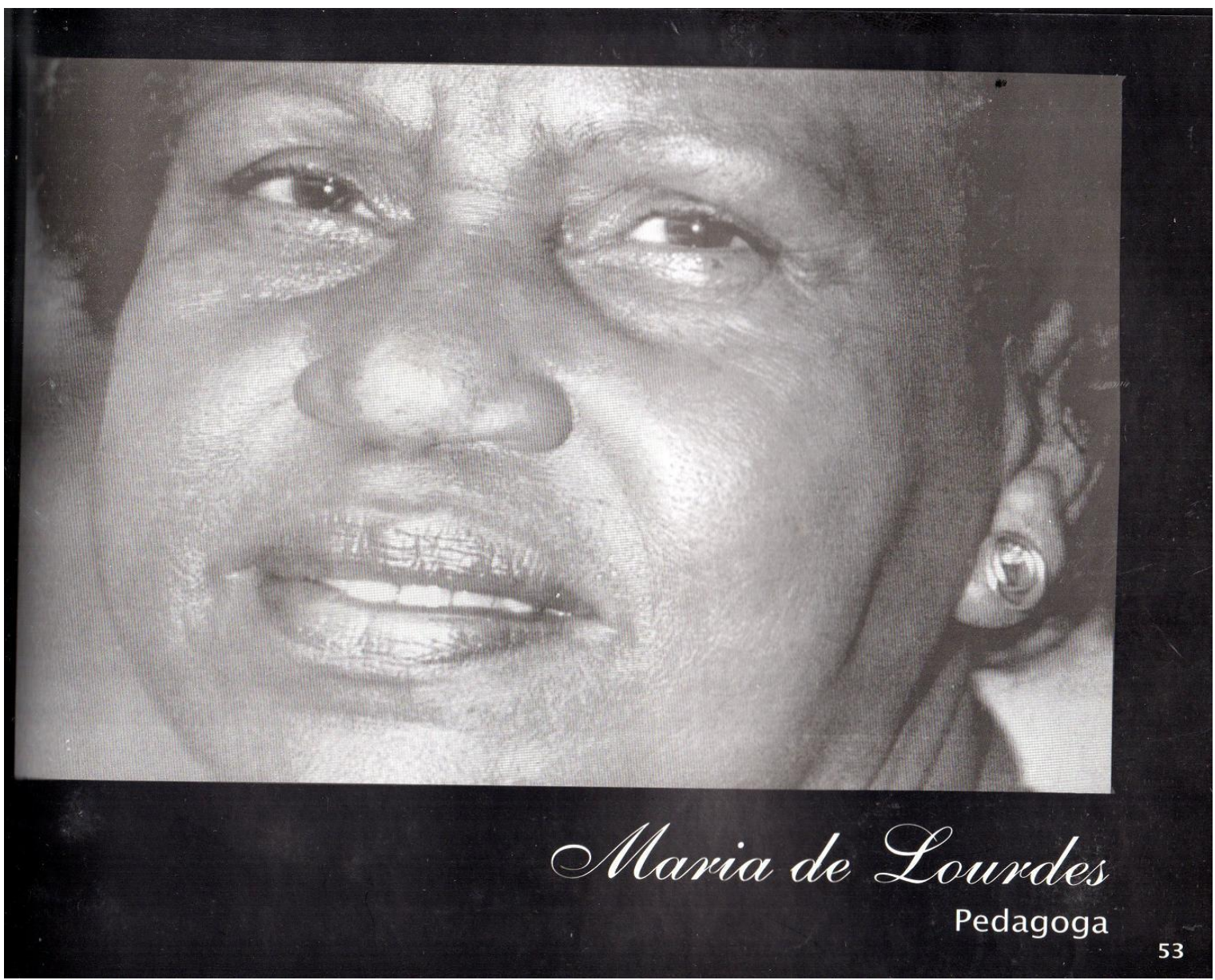

Figura 11- Dona Lourdes: foto presente no álbum "Ilustres e Anônimos". Trabalho realizado por Paulo Santos.

O projeto causou impacto também na infraestrutura do bairro Vila Operária. Antes do projeto, as ruas próximas à escola eram de terra e barro e não tínhamos iluminação pública. Com a chegada do Pré, um candidato a vereador do município mobilizou a comunidade e solicitou à prefeitura que asfaltasse as ruas próximas ao Colégio. E assim aconteceu. A primeira rua a ser asfaltada na comunidade foi a Machado Coelho (a rua principal do Colégio). Além disso, implantaram iluminação nas ruas. Todas as turmas do projeto até hoje colaboram de alguma forma com a escola, pois somos uma escola de pequeno porte. (Sra. Lourdes dos Santos)

Outro aspecto no que se refere à integração estabelecida ente escola e pré-vestibular que também merece destaque é sobre a relação constituída entre professores do PVNC - Vila Operária e os funcionários da escola, pois alguns de nossos professores conheceram o PVNC, no nosso espaço, tornaram-se alunos e ingressaram nas universidades (UERJ, UFRRJ, PUC-Rio).

Hoje o PVNC é referência no bairro e a escola, por causa do projeto, é bastante conhecida na comunidade. A maioria de alunos do curso veio por 
indicação de ex-alunos e de pessoas que conhecem o projeto. Os pais de meus alunos do ensino infantil em sua maioria procuram o Colégio Seis de Janeiro por indicação dos alunos do PVNC.

Em 2010, o Jornal "O Dia" fez uma reportagem sobre alguns prévestibulares na baixada e o PVNC - Vila Operária fez parte, divulgando ainda mais o Colégio Seis de Janeiro.

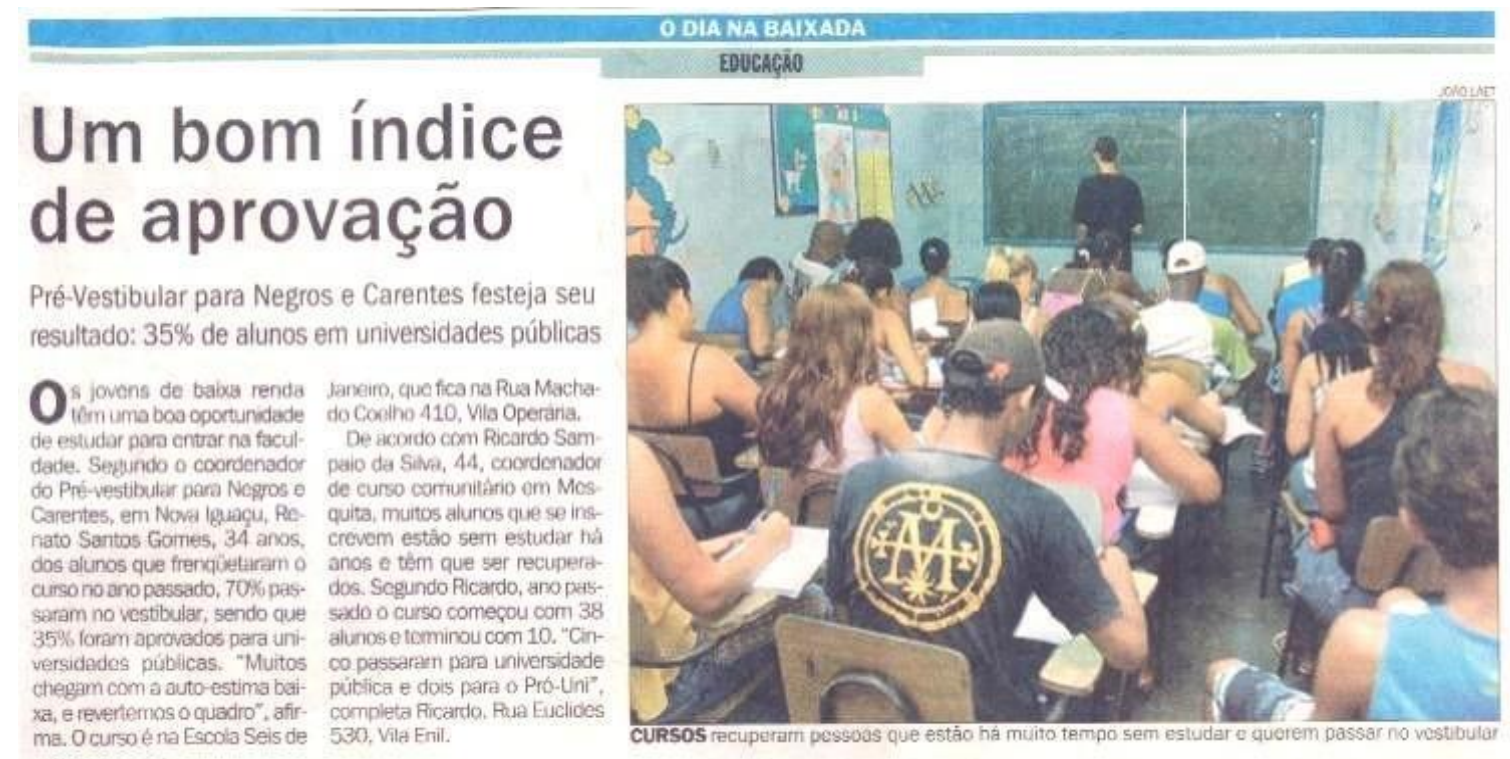

Figura 12- Em 2010, O PVNC- Vila Operária fez parte da reportagem do Jornal "O Dia" sobre os pré-vestibulares.

Mais recentemente, em maio de 2014, o Colégio foi divulgado mais uma vez através do projeto PVNC, com uma entrevista em que um dos professores do curso (Jonatan Magella) foi capa da edição. Tivemos novamente uma repercussão positiva para escola e para o PVNC. 


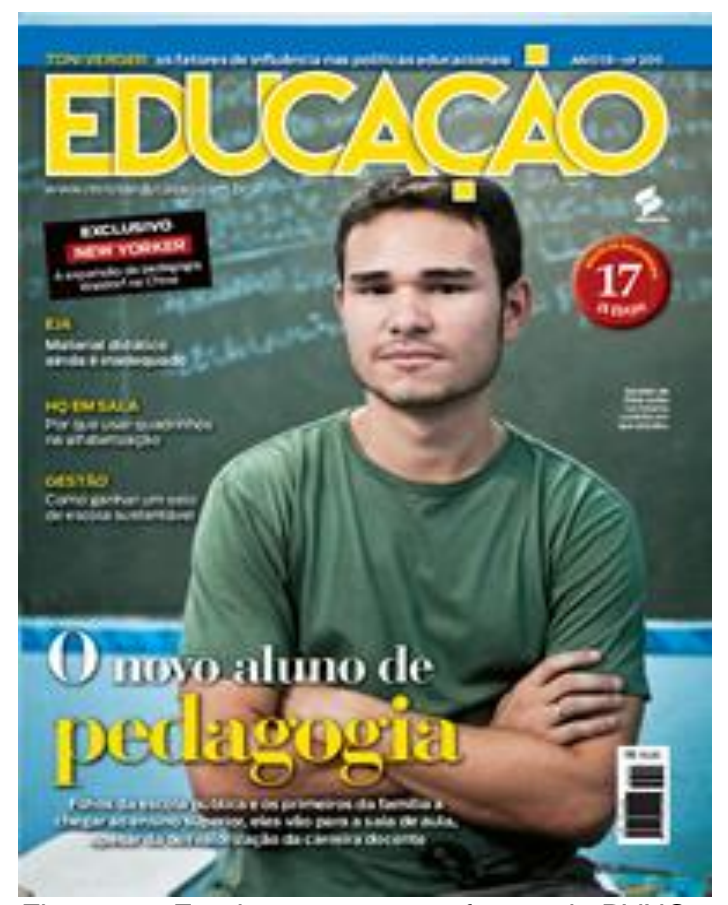

Figura 13- Ex-aluno e agora professor do PVNC, Jonatan Magella, foi capa da revista "Educação" no ano de 2014.

Outro desdobramento ainda oriundo da parceria bem sucedida é a ampliação das frentes de ação da escola que além de ter o próprio curso PréVestibular funcionando em seu espaço, a partir do pedido da comunidade forma turmas de "Aprendiz de Marinheiro" e "Pré-técnico" em reflexo de um bom número de alunos aprovados nas universidades. Muitos desses alunos também obtiveram aprovação e hoje seguem carreira militar ou estão inseridos nas escolas técnicas.

Para a Sra. Lourdes há uma imensa satisfação em ter este projeto na escola, pois trouxe para ela muito mais do que o financeiro, pois não recebe nada do projeto, até porque o PVNC não teria condições para isso. No entanto, ela fica feliz por ser uma das colaboradoras da mudança em muitas vidas de alunos que passaram por aqui e que hoje sabe (através de Renato) que estão bem sucedidos e que talvez se não tivesse conhecido o projeto, seria apenas um simples trabalhador braçal. Ela diz ainda que gostaria de manter o projeto no espaço o tempo que ele durar, pois, nesses 19 anos, muitas vidas foram transformadas, conseguindo assim uma ascensão social por meio da educação, algo que deveria ser simples de acontecer, mas que em nosso país não é. Por fim ela agradece ao PVNC com um "muito obrigado".

Como pôde se perceber, o depoimento da diretora do Colégio Seis de Janeiro reflete a realidade e as realizações alcançadas no bairro Vila Operária, beneficiando a comunidade e suas adjacências. 


\section{1. \\ O processo de construção do PVNC - Vila Operária e seus protagonistas}

De acordo com as entrevistas, os protagonistas eram especialmente vinculados a movimentos sociais e à Igreja Católica. Segundo o professor Altair, os principais protagonistas foram pessoas engajadas na paróquia de Santa Rita de Cássia, no bairro Cruzeiro do Sul (Nova Iguaçu), como Laurita, Salvador e alguns estudantes do pré-vestibular. O papel central de Laurita foi de "abrir as portas da casa dela", Salvador era um membro fundamental nas discussões e os jovens do pré-vestibular procuravam assimilar os debates em torno daquele momento para fortalecer a luta daqueles que ainda não estavam inseridos no sistema educacional de nível superior.

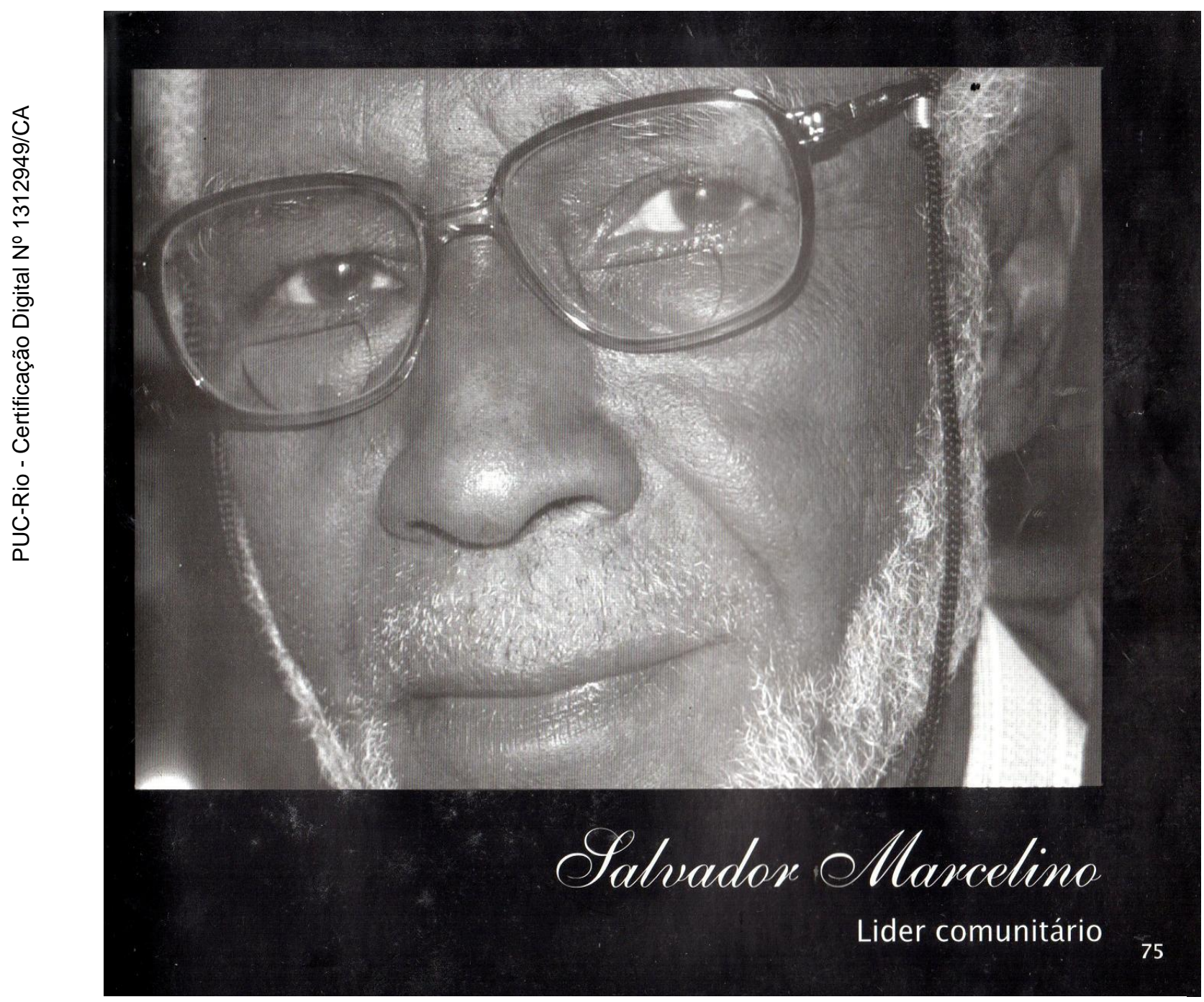

Figura 14- Seu Salvador: articulador político para implantação do núcleo PVNC.

Para o professor Ramofly, os protagonistas aparecem de forma bem 
especificada, sendo Renato, Altair e Ramofly os principais ativistas. Aparece também, destacada, a diretora do Colégio Estadual Percy e depois a diretora do Colégio Seis de Janeiro que cediam os espaços institucionais para as primeiras aulas. Desta forma, destacam-se os alunos, a comunidade local e os professores que abraçaram a ideia.

Conforme Renato Emerson:

\begin{abstract}
A construção do movimento Pré-Vestibular para Negros e Carentes (PVNC) é um desdobramento de um conjunto de estratégias do Movimento Negro nas décadas de 1970 e 1980, dentre as quais podemos destacar a escolarização dos negros como processo de construção de novas lideranças e fortalecimento de outras lideranças, e a capitalização de militantes da luta anti-racismo em diferentes espaços de luta e intervenção social, que vai legar a este novo movimento (o prévestibular) uma cultura de convergência e hibridação de valores, leituras do social e formas de atuar. (Emerson, 2003, p. 228-229)
\end{abstract}

O PVNC - Vila Operária, diferentemente da construção citada por Emerson, formou-se a partir de uma articulação entre movimento social, Igreja Católica e alguns militantes e simpatizantes do Partido dos Trabalhadores. A questão do negro não era a pauta principal num primeiro momento e sim a conjuntura econômica e política. No entanto, segundo o próprio Renato Emerson salienta:

O PVNC acaba por se constituir num espaço público de socialização, um ator plural (ou, pluriideológico), onde se torna possível, através de múltiplo pertencimento, a recomposição de identidades coletivas num cotidiano onde a democracia (essencialmente conflitiva) é radicada - as decisões são coletivas e os papéis são múltiplos e fundidos, alunos podem (e muitas vezes são) coordenadores, professores, etc. (Emerson, 2003, p. 232)

\title{
2.2.
}

\section{A formação do núcleo Vila-Operária}

Mas afinal o que motivou estas pessoas, citadas acima, desejarem formar um pré-vestibular comunitário? As razões foram várias, como a dificuldade de entrada nas universidades, principalmente, numa universidade pública, ou então financeiramente se manter numa universidade privada. Outro motivo apresentado era a discrepância de aprendizado do aluno da comunidade que concluía o ensino médio e não conseguia entrar numa universidade pública, porque a concorrência era muito grande. 
O acesso de uma classe menos favorecida às universidades até meados dos anos 90 era bem reduzido. Alexandre Nascimento apresenta a seguir uma das razões pelas quais o PVNC começa a se fazer presente na luta pela a inclusão de alunos pobres nas universidades.

No que diz respeito ao ensino superior, essa questão parece ser ainda mais complexa. O sistema de ensino superior no Brasil, composto por universidades, centros universitários e faculdades públicas e privadas, é historicamente herdeiro de um pacto social que entendemos como elitista. (Nascimento, 2012, p.56)

Quebrar esse sistema elitista também foi uma motivação para construção do núcleo PVNC. De acordo com o professor Altair Lisboa, a causa do pobre ganhou destaque nas igrejas católicas. A questão social se voltou para as comunidades e o PVNC surge como uma expectativa para dar uma direção a uma parcela de jovens descrentes de alcançar uma vaga nas universidades públicas ou privadas com bolsas. Construir uma sociedade melhor em que as pessoas pudessem transformar as suas vidas em algo positivo e o pré-vestibular veio como resposta para isso. Desse modo, o PVNC - Vila Operária - acredita que a educação é a única forma de transformação de uma classe menos favorecida e através desse olhar que os fundadores do Núcleo perceberam que as amarras da ignorância só serão quebradas a partir de uma educação mais democrática.

\begin{abstract}
A educação pode dar uma contribuição fundamental, quando e se deixar de ser uma mera transmissão de informações, para ser reprodutora e produtora de conhecimentos científicos que permitam aos alunos conhecerem o mundo, a sociedade, a história e a si mesmos em sua condição de classe, e possibilitem que rompam com o ciclo de consciência aliena, de tal forma que percebam que a socialização dos conhecimentos não deve permanecer circunscrita ao mundo das ideias, mas levar também ao usufruto dos bens produzidos pelo conjunto da humanidade. (Orso, 2014, p.15)
\end{abstract}

As palavras de Paulino José se refletem na construção do desenvolvimento do Grupo Vila Operária, uma vez que a educação pode e deve contribuir para uma consciência mais humanitária, quando bem trabalhada para a transformação do ser. Sendo assim, o Núcleo - Vila Operária procura trabalhar em suas aulas a consciência de classes, mostrando para os seus alunos que uma das possibilidades de mobilidade social é a educação.

$\mathrm{Na}$ perspectiva do professor Ramofly, a motivação se deu pelo ingresso numa universidade. A partir dessa conquista, viu-se na necessidade de retribuir e de possibilitar outros jovens da comunidade a ingressarem numa universidade. 
Ao mesmo tempo, esperava que seu trabalho servisse de exemplo para que outros pudessem ajudar na militância. Com isso, esperava obter crescimento pessoal, acadêmico e profissional.

Os professores Alzivane e Alexandre reforçam as falas já citadas dos colegas. Para eles a motivação fundamental era proporcionar a um jovem da comunidade, até então carente de oportunidades, um curso melhor para conseguir acessar as principais universidades do Estado do Rio de Janeiro.

\section{3. \\ A fase inicial de formação do núcleo PVNC - Vila Operária: fatos importantes}

Muitos fatos marcaram a fase inicial do PVNC e os entrevistados relataram uma visão muito particular desse período. Para Altair, dois fatos foram de extrema importância. Primeiramente, a morte de um companheiro que ajudou na montagem do grupo de estudo que hoje é o Núcleo PVNC. Vitimado pela violência urbana, Wellington Gomes seria mais um a estar na luta como professor de biologia.

Além desse fato, a manutenção do curso no colégio Percy, após uma tentativa de "golpe" promovido por alguns membros na época do Partido Socialista dos Trabalhadores Unificados (PSTU) também marcou a fase inicial do PVNC. Essa situação foi gerada num momento em que o curso buscava a "carta de assentamento" para se tornar PVNC. Depois de um dia inteiro de assembleia em Duque de Caxias, o curso foi assentado e quando os militantes retornaram para o espaço de estudo, os coordenadores se depararam com a mobilização de outro grupo que tentava assumir a direção do curso. Tudo acabou em muita discussão e confusão e no final prevaleceu o assentamento PVNC, a partir desse momento, Núcleo - Rancho Novo.

A coletividade mostrada em vários momentos pelo grupo que iniciou a trajetória do curso e a percepção da carência de acesso às universidades por parte de nossa comunidade também foram algo importante para o crescimento e manutenção do PVNC. A partir dessa análise, o grupo pôde determinar as ações a serem seguidas nesse novo espaço de militância.

Segundo Paulo Freire (1987), já não se pode afirmar que alguém liberta alguém, ou que alguém se liberta sozinho, mas os homens se libertam em comunhão. É nessa perspectiva que o PVNC - Vila Operária se baseia. A coletividade prevalece nas ações educacionais para uma mobilidade social. 


\section{4. \\ Por que ser um ativista do PVNC}

Várias foram as razões para os fundadores do PVNC - Vila Operária (Antigo Rancho Novo) se tornarem ativistas. Em um dos depoimentos de Altair, o professor destaca que a experiência de ter trabalhado em outro projeto voltado para os jovens estudantes numa igreja católica, localizada no município de São João de Meriti, na Baixada Fluminense, foi essencial para trazer o debate com outros estudantes do bairro Rancho Novo (Nova Iguaçu) a necessidade de montar um grupo de estudos, visando a necessidade de inserir alunos de escolas públicas nas universidades. Logo após esse período, o surgimento de um pré-vestibular numa paróquia em Heliópolis (Belford Roxo) reforçou o desejo de realizar também no Rancho Novo um curso pré-vestibular que pudesse atender os anseios da comunidade, transformando-a em uma realidade diferente da vivida naquele momento pelos jovens. Uma realidade de violência, desemprego e falta de perspectiva.

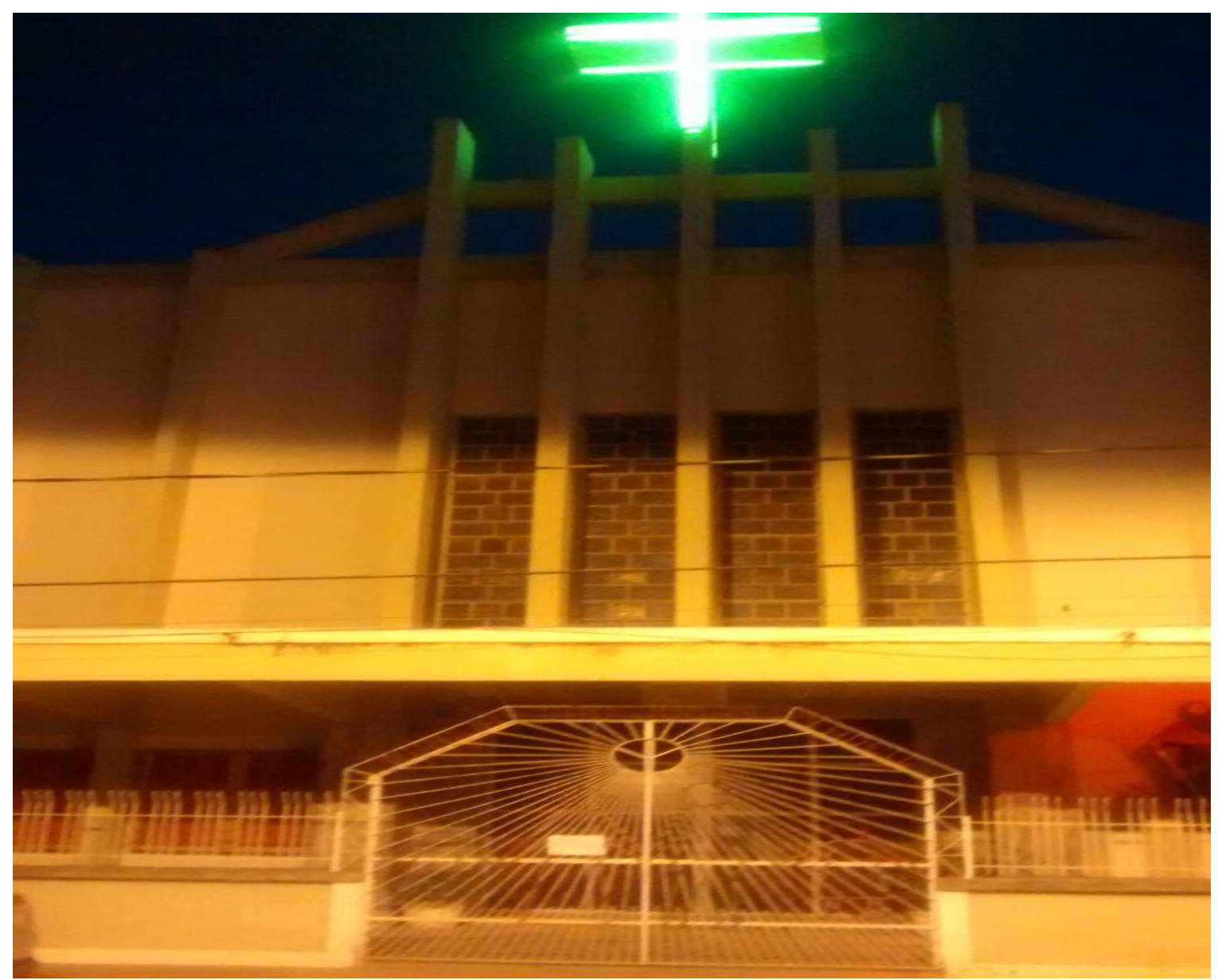

Figura 15-Paróquia de São Judas Tadeu: local onde funcionou o Núcleo PVNC - Heliópolis. 
Em outro caso, a experiência adquirida na universidade e em outros movimentos sociais, como o MST, motivou a por em prática seu conhecimento numa causa voltada para a sua própria comunidade. O curso de história fortaleceu o embasamento político necessário para refletir sobre o momento de crescimento dos movimentos sociais, em especial, educação popular, fortalecido pelos PVNCs.

Já para os professores Alzivane e Alexandre, a possibilidade de experiência profissional dentro daquilo que queriam lecionar, aliada a vontade de melhorar a perspectiva dos estudantes da comunidade foram o diferencial para se tornarem colaboradores do projeto.

\section{5 .}

\section{A importância do PVNC para a comunidade}

Além de dar base para conseguir o ingresso nas universidades, o PVNC tem uma importância social, como o fortalecimento da identidade do cidadão negro e da consciência de ser pobre. A possibilidade, por meio dos estudos, de conquistar uma mobilidade social ascendente e de buscar seus direitos através de todo um conhecimento adquirido durante sua trajetória no projeto também é relevante para o avanço da cidadania. Cidadania essa que é amplamente discutida nas aulas de "Cultura e Cidadania" implementadas desde a criação do Núcleo - Vila Operária (Antigo Rancho Novo).

O lugar privilegiado da discussão racial num pré-vestibular é a disciplina Cultura e Cidadania. Sua eleição enquanto componente e signo fundamental da dimensão política dos cursos, em detrimento de uma capilarização das discussões políticas na construção de todas as disciplinas, não exclui a politização de algumas aulas, mais isto fica muito mais à mercê do critério do professor - fazendo uso da prerrogativa de autonomia pedagógica. Cultura e Cidadania é, portanto, o momento privilegiado de emergência da discussão sobre a questão racial, em todos os cursos pré-vestibulares populares, ligados ao PVNC ou não. (Emerson, 2003, p.237)

Outro fator importante que o PVNC implementou na comunidade era que não bastava o aluno apenas entrar numa universidade, ele tinha que entrar e fazer a luta dentro da universidade, de continuar na universidade a propagação de valores que o PVNC defendia em seu núcleo. Desde modo, espera-se que esse aluno com base do PVNC fizesse valer a voz do curso dentro da universidade. Essa ponte de transição entre comunidade e universidade é que fortalecia as aulas de "Cultura e Cidadania" e uma das expectativas do pré era que esse aluno retornasse para dar continuidade à luta da educação popular. $O$ 
retorno que esses alunos davam à comunidade acaba gerando um simbolismo de conquista através dos seus próprios esforços, gerando na comunidade uma esperança de dias melhores, tendo em vista que, tratando-se de uma área carente e violenta, qualquer resgate social torna-se uma conquista.

$\mathrm{Na}$ "Carta de Princípios", o objetivo das aulas de "Cultura e Cidadania" também era destacado:

O objetivo da matéria CULTURA E CIDADANIA é realizar um amplo debate socialhistórico, no sentido de potencializar as ações políticas e culturais dos educandos e educadores do PVNC. a partir/para valores humanitários e socialistas (solidariedade, igualdade e respeito aos seres humanos) e na perspectiva de desenvolver um trabalho de conscientização e formação de militância para as lutas populares por democracia e justiça social. (p.13)

De acordo com a coordenação do Núcleo, como desdobramento da disciplina "Cultura e Cidadania", o PVNC - Vila Operária promove várias atividades culturais de interação entre professor-aluno-comunidade, professoraluno-família, tendo em vista que esses alunos passam seus finais de semanas e feriados dentro do pré. Como forma de evitar conflitos em casa em virtude da ausência do filho (aluno) que estava todo final de semana e feriado de $8 \mathrm{~h}$ da manhã às $17 \mathrm{~h}$, o PVNC realizava vários eventos comunitários de integração.

Essa maneira de integração foi realizada primeiramente com almoços entre pais e filhos, já que este aluno ao entrar no projeto acabava tendo uma mudança brusca em sua rotina de finais de semana com sua família. O almoço era realizado duas vezes ao ano, o primeiro era realizado na semana que antecedia o dia das mães e o segundo era na semana que antecedia o dia dos pais. Nesta interação os coordenadores e professores procuravam orientar os familiares quanto a importância daquele momento para seus filhos, buscava-se que seus entes queridos pudessem acompanhar a caminhada desse aluno, mas sem a cobrança exacerbada, tendo em vista que o vestibulando já sofre uma pressão natural, pois seu envolvimento com o pré e o vestibular por si só já é uma cobrança.

Neste momento de confraternização era a oportunidade que pais e filhos tinham para curar algumas feridas familiares que, em muitas vezes, surpreendiam a coordenação e professores, pois os alunos, em alguns casos, não conseguiam ter um diálogo com seus pais em casa, já que sua vida naquele momento era estudar para buscar a aprovação sonhada e desejada por alguns de seus familiares. 
Além disso, o encontro também servia como uma oportunidade dos pais conhecerem o projeto e o espaço onde seus filhos permaneciam todos os finais de semana e feriados. A partir dessas reuniões, surgiu a ideia de associação de pais do pré-vestibular para negros e carentes do núcleo Vila Operária que tinha o objetivo de acompanhar os casos extra pré, ou seja, esse grupo de pais procuravam se aproximar daqueles alunos que tinham característica de faltosos, visitando as residências desses alunos para saber o motivo de sua falta no curso.

Por meio dessas visitações, era possível saber o porquê do abandono. Dentre os motivos encontrados, a parte financeira juntamente com a distância era a que mais contribuía para a ausência do aluno no curso, já que muitos não tinham condições de arcar com a passagem todo fim de semana. Outro caso comum, era que a própria família não acreditava que após a conclusão de um curso na universidade as condições financeiras, sociais e culturais poderiam melhorar, gerando uma frequente contestação por parte da família em relação ao seu futuro profissional.

Por se tratar de uma comunidade carente, para alguns pais era mais importante o trabalho do que o estudo, pois eles acreditavam que seus filhos tinham a obrigação de ajudar nas despesas domésticas, deixando assim o estudo para o segundo plano. A associação de pais procurava sucintamente intervir em algumas situações e tendo sucesso em alguns casos, criando um fortalecimento e envolvimento entre pais, professores, coordenadores, comunidade e vestibular.

Outra maneira de integração no projeto foi o encontro de professores, no dia 15 de outubro, onde realizava o futebol dos professores do curso contra o time da comunidade, onde os alunos também participavam do evento. Essa festividade era realizada no campo próximo ao projeto e a comunidade é que presenteava o projeto com o evento.

Além do futebol a comunidade realizava o almoço em homenagem aos professores, acreditando que era o momento de grande descontração entre a comunidade e o pré-vestibular. O futebol ficava na responsabilidade da família Beira Rio, é um time formado há 38 anos na comunidade, em que seus familiares se tornaram alunos do projeto, por isso a homenagem aos professores do pré Vila Operária.

A família Silva, que faz parte da diretoria da Associação Atlética Beira Rio, tornou-se parceiro do núcleo mesmo após a passagem de seus familiares pelo projeto. Não só nas atividades extraclasse, como contribuição do andamento do 
núcleo, onde estes se tornaram coordenadores e professores do núcleo.

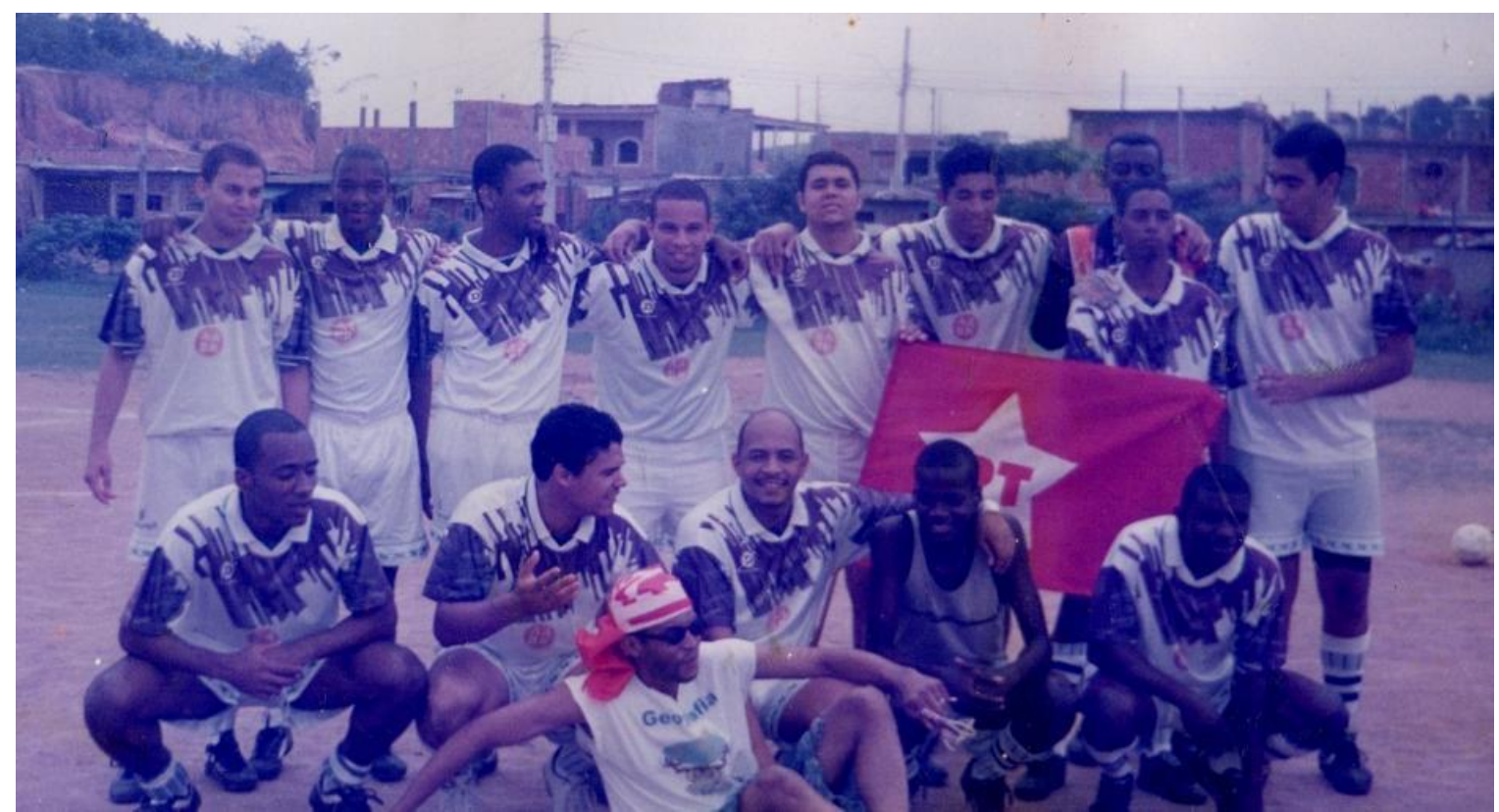

Figura 16- Futebol: momento de integração entre professores, alunos e comunidade.

Outra característica de envolvimento com a comunidade foram os eventos culturais, entre eles o "Botequim do Pré", que tinha como objetivo uma aproximação com a comunidade local. Por ser um bairro da periferia o Funk estava muito marcado na cultura dos alunos e ideia do botequim cultural era proporcionar músicas que pudessem ser aproveitadas nas aulas das disciplinas de cultura e cidadania, história e geografia.

O botequim era realizado com voz e violão apresentando a MPB, pois estas músicas não faziam parte da realidade dos alunos e comunidade, o repertório era selecionado rigorosamente pelos professores de literatura, história e geografia.

Esse evento era realizado duas vezes ao ano, geralmente um próximo ao simulado, onde acontecia no mês de junho e o outro em novembro as vésperas do vestibular da UFRJ. Com isso, se percebia uma carência por parte dos discentes a dificuldade de interpretações da letra da música em relação ao tempo espaço e contexto, por outro lado, notava-se a busca desses alunos para interpretar as aulas de geografia, história e literatura, nos simulados do núcleo.

No entanto, o evento mais aguardado no PVNC - Vila Operária era o "Baile dos Calouros", no qual os alunos aprovados no vestibular do ano anterior eram homenageados e apresentados para a toda a comunidade. O objetivo do baile era mostrar que passar no vestibular não era impossível, servindo também de 
incentivo para os novos alunos do curso.

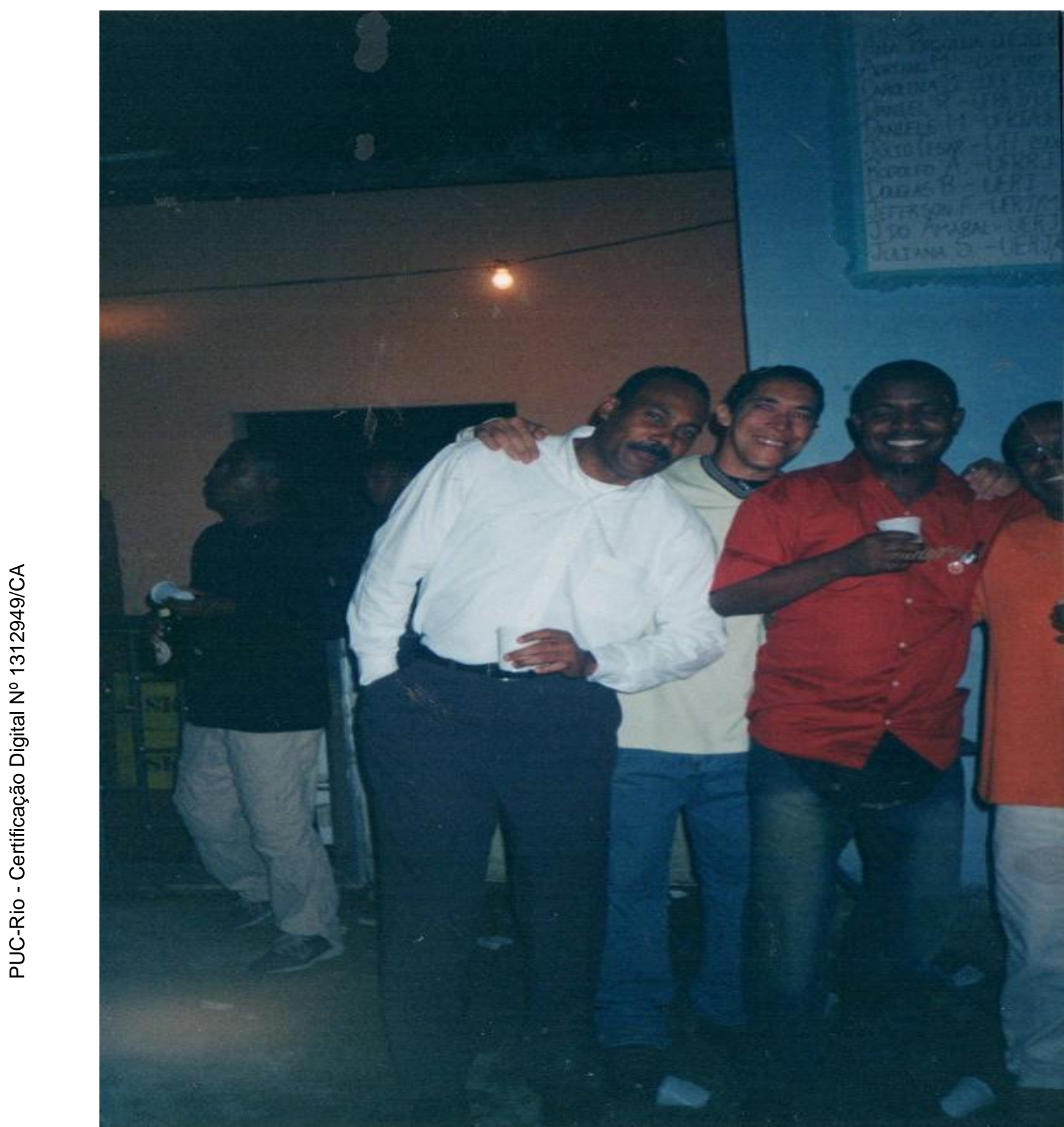

Figura 17- Baile dos Calouros: na parte superior da foto um pedaço do cartaz com os nomes dos aprovados.

Essa é uma das ações importantes do PVNC - Vila Operária que é ressaltado por uma das ex-alunas do curso, Vanessa Alves. Na época professora e coordenadora do curso, atualmente, foi uma dessas pessoas homenageadas. Ela relata o que foi esse momento, mostrando um sentimento que pode ser compartilhado por outros tantos alunos que participaram desse evento. 
O "Baile dos Calouros" foi a comemoração da concretização de um sonho, em que na minha realidade seria impossível, pois sou filha de costureira com metalúrgico e ambos só têm o ensino fundamental. Mas busquei e batalhei pelo meu sonho e através do PVNC - Vila Operária, consegui realizar o meu grande sonho, que foi entrar para a universidade. Vale ressaltar que fui a primeira a cursar o ensino superior de toda a minha família.

Então, o meu baile foi um marco em minha vida, uma festa que comemorei não somente a minha conquista, mas também a conquista de meus amigos que passaram os finais de semana comigo no projeto estudando.

O baile era feito para homenagear os alunos do projeto que tiveram a aprovação no vestibular e se tornou um marco na comunidade, fazíamos uma vez ao ano e ali confraternizavam alunos, familiares dos alunos e comunidade.

Todo o ano a comunidade esperava pelo baile do projeto, pois era um local sadio e ali também serviu de estímulo para outros que pensavam em uma ascensão na sociedade. Com o baile mostrávamos de que era possível uma pessoa que está à margem da sociedade, cujo seu destino seria de ser operário, poderia chegar a uma universidade e mudar as estatísticas, já que poucos conseguiam acesso ao ensino superior.

Com isso, o projeto conseguiu mudar a vida de muitos e talvez se não existisse o PVNC, estariam trabalhando como operário". (Vanessa Alves)

Para reforçar a fala anterior, o ex-aluno e agora professor, Sérgio Roberto, complementa:

"O baile dos calouros é para quem estudou no PVNC um momento de realização, pois seu nome fica numa lista de aprovados que é exposta e depois assinamos um quadro o nosso nome, marcando assim nossa passagem no PVNC. Nesse baile, a minha família e meus amigos que fiz durante o curso comemoraram comigo a aprovação de todos que passaram no vestibular naquele ano. Um momento muito especial, pois nesse baile estavam ainda aqueles que não tinham conseguido a aprovação, mas mesmo assim comemoraram juntos, na certeza que seu nome em breve estaria ali". 


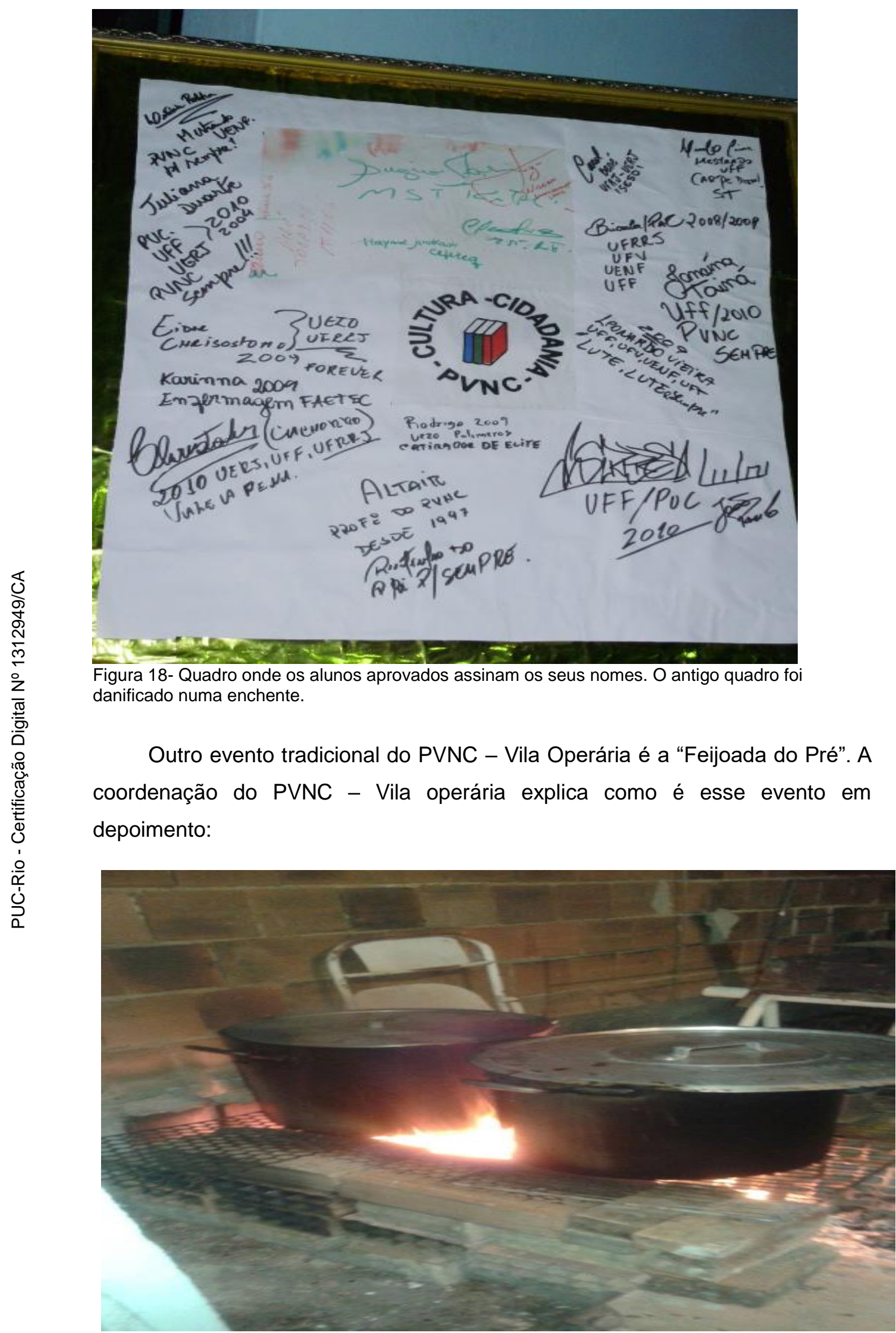

Figura 19- Feijoada do Pré sendo preparada. 
"A feijoada é um prato afro-brasileiro de origem africana, inventado pelos africanos que estavam aqui no Brasil. Com o passar dos anos, tornou-se um prato típico brasileiro".

Mas para o PVNC - Vila Operária, a feijoada é também um momento de reflexão com os alunos. É onde nós aproveitamos para debater sobre nossas origens.

Os alunos têm aula de História da áfrica, onde procuramos valorizar a cultura africana em nossa realidade. É passado para eles que todos nós somos filhos do continente africano, que a maior parte do que sabemos é de origem africana.

E passado também que temos que ter orgulho de nossa cor e não vergonha das nossas características físicas. Fazemos um debate sobre o racismo, mostrando que ele existe e que temos que saber the dar com a situação, pois racismo, segundo a Constituição Federal é crime inafiançável (art $5^{\mathfrak{a}}$ ). Então, isso é discutido com eles, pois é uma maneira de buscarmos nossos direitos como cidadão.

Procuramos passar também nessas aulas que a discriminação vem desde a época da escravidão e após a abolição em 1888, não houve um programa de inclusão do negro na sociedade e sim a exclusão que, posteriormente, agravouse. Então, hoje somos o resultado desse mal planejamento da inclusão e ascensão social da maior parte da população que é negra (afrodescendentes).

Tentamos criar assim uma consciência em nossos alunos para que eles mudem esta realidade e consigam chegar à classe social que não é comum ver pessoas negras, pois, se observarmos as classes $A$ e $B$ raramente, vemos uma pessoa de cor negra.

Durante o evento, acontece também a apresentação de capoeira como forma de valorização mais uma vez da cultura africana, já que essa arte é reconhecidamente de origem africana e remete à luta que esse povo desenvolveu para sua proteção contra os senhores de escravo. Além disso, os próprios cantos servem de referência geográfica e histórica para o desenvolvimento das aulas. A "Feijoada do Pré" e a capoeira tornaram-se uma identidade do Núcleo - Vila Operária". 


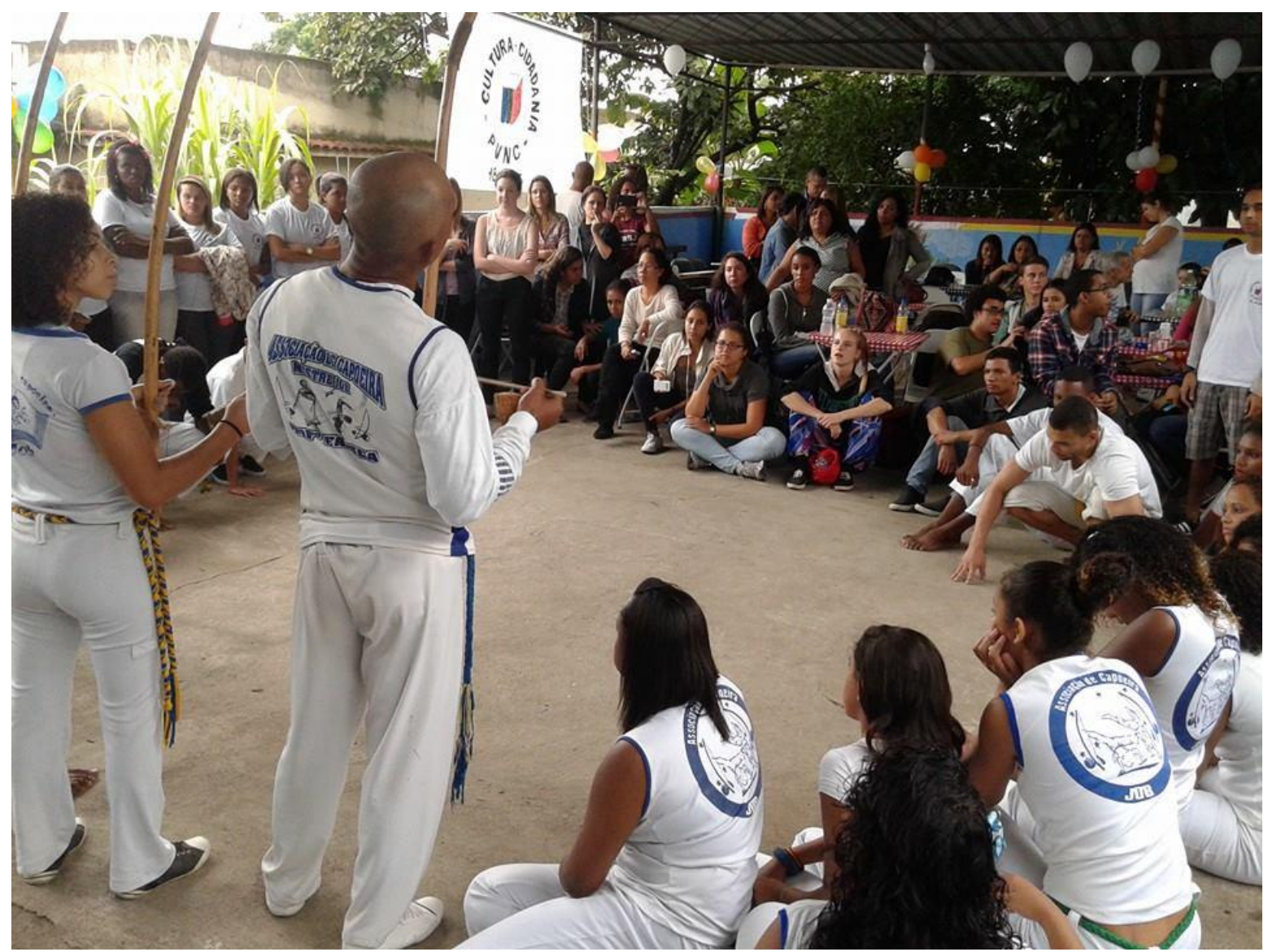

Figura 20- Capoeira do PVNC: evento acontece anualmente durante a "Feijoada do Pré".

\section{6. \\ Formação da coordenação e seleção de docentes e discentes}

A criação da coordenação teve como critério principal a identificação de pessoas com as causas sociais em prol da comunidade. Responsabilidade e disponibilidade de tempo também eram um critério essencial para que uma pessoa assumisse a coordenação do curso.

No caso dos docentes, a disponibilidade, o comprometimento com a causa social, o interesse pelas propostas do curso e pela metodologia adotada eram os critérios primordiais para a seleção. No entanto, alguns docentes não tinham essa visão de militância, porém com o passar do tempo, eles entendiam a filosofia e compreendiam a importância de separar voluntariado de militante.

A "Carta de Princípios" do PVNC também servia como parâmetro para os novos ativistas do Núcleo - Vila Operária. Nela era ressaltado o perfil dos professores militantes e dentre as recomendações, a consciência do alcance político, social e educativo do Movimento Pré-Vestibular para Negros e Carentes era a primeira citação na Carta. A seguir, outros itens constituíam o corpo da 
Carta:

- Sejam altruístas e dotados de elevado sentimento de solidariedade humana;

- Reconheçam a importância de não conservarem qualquer preconceito racial, de gênero, político, ideológico e religioso, comprometendo-se a respeitar e tratar a todos de forma igual;

- Disponham-se a praticar e incentivar os alunos à prática da SOLIDARIEDADE ATIVA;

- Possuam sólido conhecimento das disciplinas que se disponham a ministrar, mesmo não sendo academicamente formados;

- Busquem desenvolver a consciência critica dos alunos frente a realidade social, política, econômica e racial;

- Sejam receptivos às instruções que lhes forem passadas pela coordenação de seu Núcleo e, em caso de dúvidas, consultar a dialogar com esta.

- Saibam que se fizerem pelo aluno qualquer coisa que este possa fazer, sua ajuda se transformará num ato paternalista, pois induzirá o "beneficiado" a indolência, auto depreciação e dependência.

- Valorizem o ato de ouvir e aceitar, de forma a envolver os alunos num relacionamento franco e confiante;

- Que faça uso de diferentes métodos e seja consciente das limitações dos alunos:

- Tenham consciência do caráter inovador do projeto, como um questionamento ao sistema.

A "solidariedade ativa" por parte dos alunos é um dos grandes desafios enfrentados pelos professores, tendo em vista o processo de rotatividade dos alunos, o que dificulta a condição para ele compreender a filosofia implementada pelo Núcleo nas aulas de "Cultura e Cidadania".

Outro item que cabe uma reflexão é o que alerta sobre o possível ato de paternalismo por parte dos professores. Para o PVNC, o aluno deve ter a sua consciência despertada para o seu desenvolvimento intelectual e encarar os desafios impostos, principalmente, pelas atividades propostas para conseguir a sua aprovação no vestibular. Porém, em muitas vezes, o professor precisa ter um cuidado para lidar com o grau de dificuldades dos alunos que vem com uma defasagem de conteúdo e com isso sem perceber acaba caindo em um dos 
maiores cuidados que o PVNC tem que seria em não cair numa ajuda paternalista. Então, como não cair numa ajuda paternalista em que muitas vezes o alunado com baixa autoestima e com o conceito que não sabe nada acaba desistindo da luta por um ingresso no ensino superior?

Uma possível resposta dessa indagação começa por uma reunião de professores e de coordenadores, onde será debatido esse tema complexo e real dentro dos núcleos, buscando sugestões que acabam entrando em prática por meio de disciplinas que são lecionadas para construir uma base de fortalecimento de conteúdo. Disciplinas chamadas pelo Núcleo - Vila Operária de "matemática zero", "português zero", "leitura e interpretação de textos", por exemplo, ajudam o aluno a superar o trauma do "não sei nada", nivelando-os um grau acima do encontrado em sua entrada no curso.

Todo o exposto no parágrafo anterior acaba coincidindo com o perfil dos professores que atuam nos PVNC,s. Há outros métodos que podem ser desenvolvidos, ficando a cargo de cada núcleo de acordo com a sua realidade. No caso do Vila Operária, é comum ex-alunos aprovados no vestibular relatarem aos novos alunos suas experiências durante o tempo no curso, demonstrando que passaram pelas mesmas dificuldades, pelas mesmas angústias e incertezas e mesmo assim, superaram as suas próprias desconfianças e conseguiram compreender que mais do que passar no vestibular é reconhecer a sua defasagem educacional e não se esquivar dos desafios.

Por fim, vale comentar o último item do perfil dos professores que trata da consciência do caráter inovador do projeto, como um questionamento ao sistema. Espera-se assim que o professor engajado na luta para um processo mais democrático educacional possa utilizar das suas experiências adquiridas dentro do movimento PVNC em suas mais diversas áreas de atuação profissional, já que nem todos os ativistas atuam na licenciatura.

O exercício da prática cotidiana nos movimentos sociais leva ao acúmulo de experiências, onde tem importâncias, onde tem importância a vivência do passado e no presente para a construção do futuro. Experiências vivenciadas no passado, como opressão, negação de direitos etc., são resgatadas no imaginário coletivo do grupo de formar e favorecer elementos para a leitura presente. (Gohn, 1992. p.18)

Em depoimento, o professor Marcelo relata como foi sua chegada ao PVNC - Vila Operária:

'Eu estava no $5^{\circ}$ período da Faculdade de Letras da UFRJ e ainda não tinha atuado como professor. Foi quando uma amiga da rua em que eu morava me disse que o curso onde trabalhava estava com carência de professor de português. Já estávamos no segundo semestre do ano e, segundo ela, a vaga 
era de urgência. Não sabia nada sobre o curso, até achava que ganharia salário, carteira assinada e, além disso, claro, experiência na profissão. Minha amiga comunicou à coordenação do curso sobre o meu interesse e logo foi marcada uma reunião. No dia da reunião, lembro-me que além da coordenação, outros professores que já eram militantes participaram da conversa. Nela, pude compreender melhor o que era o PVNC e o discurso carregado de entusiasmo e verdade me fez acreditar no projeto. Não havia salário, ganhávamos apenas ajuda de custo para a passagem do transporte. Com isso muitos amigos de faculdade diziam que eu era doido em trabalhar "de graça", que eu deveria procurar um emprego remunerado, mas essa fala não foi o suficiente para tirar o meu interesse em contribuir com o curso.

Em menos de uma semana, debutava numa sala de aula. Estava muito nervoso no dia, havia mais ou menos 30 alunos presentes na minha estreia. Antes de começar a aula, fui apresentado pela coordenação aos alunos e como me senti muito bem acolhido por todos, consegui me acalmar, dando início à aula.

Bem, já se passaram muitos anos desde esse dia, hoje posso dizer que aprendi muito mais do que ensinei durante todo esse tempo no PVNC - Vila Operária. Também pude crescer profissionalmente e academicamente. Sou professor concursado do Estado com duas matrículas de 30h. Além disso, especializei-me em Língua Portuguesa e posteriormente ingressei no mestrado em "Estudos de Linguagem", ambos pela UFF, tendo hoje o título de Mestre. Creio que essas conquistas só foram possíveis graças ao aprendizado que consolidei ao militar no PVNC. Não a toa, participo ainda como professor do curso, ajudando também novos companheiros da minha disciplina a iniciarem sua carreira por meio de conselhos e dicas'. (Marcelo Magalhães)

\section{7. \\ Depoimentos de ex-alunos acerca da própria trajetória do PVNC - Vila Operária}

Quanto à escolha dos discentes, os coordenadores procuravam traçar o perfil do aluno por meio de entrevista, enfatizando nas perguntas a situação socioeconômica, familiar e escolar. Desse modo, o PVNC - Vila operária contempla um dos objetivos contidos na "Carta de Princípios", como podemos observar a seguir:

Criar condições para que os estudantes discriminados, por etnia, gênero ou situação sócio-econômica concorram nos vestibulares das Universidades Públicas, em condições concretas de aprovação e inclusão no ensino superior (Carta de Princípios, p.6).

No que se refere aos critérios de elegibilidade das primeiras turmas do PVNC - Vila Operária, alguns ex-alunos relatam como foi esse processo.

Cláudio, ex-aluno do PVNC, relata como foi esse momento de ingresso no curso:

'Há uns 14 anos atrás, as pessoas de comunidades pobres como a minha (na época, morro do Falcão - Heliópolis, Belford Roxo) eram mais desinformadas a respeito de como fazer um concurso público; até mesmo de como se inscrever! A 
realidade era bem diferente, e as escolas não preparavam integralmente os alunos (e ainda não preparam!) para os diversos concursos públicos e, de certa forma, nem mesmo para o mercado de trabalho. Elas, "focando" o básico do currículo escolar, não entram nas especificidades de um concurso, como o do vestibular'. (Cláudio, ex-aluno do PVNC)

No Estado atual das coisas, a exclusão social de que os negros são as principais vítimas no Brasil deriva de alguns fatores, entre os quais figura o esquema perverso de distribuição de recursos públicos em matéria de educação. A educação é mais importante entre as diversas prestações que o indivíduo recebe ou tem legítima expectativa de receber do Estado. (Gomes, 2001, p.138)

Ainda segundo Cláudio, muitos alunos da época terminavam o Ensino Médio e procuravam ingressar no mercado de trabalho. Logo percebiam que não estavam preparados não só para o trabalho, mas também para a vida. Com isso, é comum a entrada precoce no mercado de trabalho informal (sem carteira assinada) em bairros periféricos da cidade. Dessa forma, Cláudio percebeu a necessidade de continuar estudando em busca de condições melhores para o mercado de trabalho e retrata o seguinte:

\begin{abstract}
'Naquela época, havia mudado (com muito custo) para um emprego, que, apesar do salário baixo, assinava a carteira e disponibilizava uma jornada de trabalho menor, ideal para que pudesse estudar. Contudo, possuindo pouca ciência de como seria um ensino de qualidade e onde eu poderia encontrá-lo, resolvi que estudaria em uma faculdade particular mesmo, e de preferência, em uma que estivesse bem próxima ao local de trabalho, a fim de facilitar o meu trânsito entre as duas instituições. Encontrei uma que se enquadrava nas características desejadas, mas não fiz a inscrição ainda, pois iria pensá-la. Na semana seguinte comentei com um meu amigo o que eu pretendia fazer, e ele repassou a outro amigo nosso. Este último, conhecendo por alto, o PVNC convidou-nos para ir até lá a fim de se era possível ainda fazer a inscrição do preparatório para o vestibular. Quando chegamos lá, assim como nós, muitos alunos estavam tentando entrar no PVNC para se preparar no vestibular. Como a escola que cede o espaço para o pré-vestibular não possuía muitas salas, havia uma lista de espera, e, antes, uma espécie de entrevista feita pelo próprio Renato. Graças ao bom Deus, conseguimos entrar, estudamos juntos, e eu estou lá como professor voluntário até precisamente ao dia de hoje!'. (Cláudio, ex-aluno do PVNC)
\end{abstract}

Cláudio ainda destaca que o PVNC foi responsável por elevar sua autoestima, já que a todo o momento era incentivado e estimulado a estudar em busca de uma universidade pública, algo que para ele era impossível antes de entrar no curso.

'De fato, precisaria mesmo de esforço e educação, porque, mesmo trabalhando, não teria condições de custear uma faculdade particular, próxima ao trabalho, e entrar em uma universidade pública não era uma coisa muito fácil para o filho de um motorista e de uma empregada doméstica. Naquela época, as coisas não eram muito fáceis para entrar em uma faculdade pública. Em consequência disso, a minha baixa autoestima não me deixava, pelo menos no início, ver que era possível alcançar tal meta. Certamente o PVNC teve muito trabalho comigo, já que era muito baixa a minha autoestima. Devido a esse incentivo, alunos 
vinham de lugares bem distantes do Rio de Janeiro, como, p. ex., Bangu, Campo Grande, etc'.

Cláudio é um desses alunos que deram retorno ao PVNC - Vila Operária. Desde 2004, leciona as disciplinas Língua Portuguesa e Literatura no curso, contribuindo assim para a continuidade do projeto.

'Graças a Deus e ao PVNC, consegui chegar ao meu objetivo: tornar-me um professor. Tenho consciência de que sem o auxílio do pré-vestibular nessa jornada, não teria conseguido. O PVNC me ensinou também a importância de não somente de acumularmos conhecimento, mas também de reparti-lo. Por isso, desde 2004, atuo como professor, transmitindo esse conhecimento adquirido em uma universidade pública e de qualidade, como é o caso da UFRJ. Tenho orgulho de fazer parte dessa história (18 anos!) como aluno (2001-2002) e como professor. Ao longo desses anos, perdemos as contas de quantos jovens ajudamos. Jovens estes que, na sua maioria, não apresentavam muitas perspectivas de crescer na vida, de ampliar os horizontes com a educação. Enfim, parabéns PVNC, parabéns, Renato pelo trabalho de qualidade, de abnegação e de prestação de serviço feito não só à comunidade de Vila Operária, mas também a de comunidades adjacentes'. (Cláudio)

Outra ex-aluna do PVNC, Amanda Alves, faz um relato de como ingressou no curso. A fala dela complementa o que já foi dito pelo professor Cláudio e, de certa forma, reflete a realidade de vários outros alunos do projeto.

Amanda Alves da Costa, uma negra e carente oriunda de uma família de cinco pessoas. No ano de 2001, ao realizar o terceiro ano do Ensino Médio, sem saber o que seria de sua vida, encontra um projeto que mudaria sua vida.

Para participar, descubro que tinha que fazer uma inscrição e passar por um processo seletivo para concorrer à vaga. O PVNC - Vila Operária entra em minha vida num momento em que minha família passava por um quadro de desemprego. Ali começava um sonho, uma caminhada que não foi fácil. Não consegui ingressar na universidade na primeira tentativa, mas não desisti dos meus sonhos e na terceira tentativa consegui. Muita felicidade saber que enfim era uma aluna de ensino superior. (Amanda)

A educação para a cidadania democrática consiste na formação de uma consciência ética que inclui tanto sentimentos como razão; passa pela conquista de corações e mentes, no sentido de mudar mentalidades, combater preconceitos e discriminações e enraizar hábitos e atitudes reconhecimento da dignidade de todos, sejam diferentes ou divergentes. (Benevides. p.148,1998)

Amanda é um exemplo de persistência de luta em busca de uma oportunidade através do ensino superior, já que acreditava que esse ingresso a levaria a uma mobilidade social que de fato ocorreu.

'Hoje posso dizer que sou o que sou, porque Deus colocou pessoas que acreditam nas mudanças, nas conquistas das pessoas. O Pré-Vestibular existe com a finalidade de resgatar vidas, de inserir e mostrar que também somos capazes de 
chegar a algum lugar. Foi importante na época do vestibular, foi importante durante a faculdade e é importante na vida de muitos.' (Amanda Alves)

Por meio dos depoimentos dos professores Cláudio e Amanda, ex-alunos do PVNC - Vila Operária, é possível perceber a grandeza desse movimento de educação popular na mobilidade social na vida desses militantes da periferia da Baixada Fluminense. Os relatos desses professores serviriam para tantos outros colegas de profissão que chegam ao PVNC, já que compartilham de uma realidade bem próxima por estarem numa condição social desfavorecida e por serem moradores de uma mesma região. 


\section{3 \\ Conclusão}

Esta dissertação abordou a formação do PVNC - Vila Operária em seus primeiros 5 anos (1996-2001). A partir de uma investigação empírica, buscou-se compreender como que a construção desse Núcleo foi feita, por meio de relatos, entrevistas e depoimentos de seus fundadores e de algumas lideranças comunitárias do município de Nova Iguaçu.

Durante a pesquisa de campo, foram realizadas diversas visitas aos militantes da formação do PVNC, com o intuito de entender os reais motivos da construção e do envolvimento deles com o Núcleo. Com isso, pode-se constatar que o PVNC - Vila Operária surgiu como um movimento de educação popular de resistência contra o sistema capitalista educacional. Sua base de liderança era formada por vestibulandos, universitários, agentes comunitários (oriundos da igreja católica e do Partido dos Trabalhadores) que procuravam compreender o momento vivido na década de 90 . Buscavam, assim, alternativas para que a população de baixa renda, mais especificamente filhos de operariado, conseguissem ingresso no ensino superior.

Com a base formada, o PVNC - Vila Operária passou a ter uma bandeira de luta, deixando de ser apenas uma referência ao operariado, para se tornar um símbolo de uma resistência racial no bairro Vila Operária. Sendo assim, além de possibilitar a entrada de um estudante numa universidade, ou seja, proporcionar uma mobilidade social, o PVNC também tinha como objetivo conscientizar socialmente, culturalmente e politicamente seus alunos e professores. Para isso, as aulas de "Cultura e Cidadania", trabalhos de campo e algumas atividades culturais do Pré, como, por exemplo, a feijoada, a capoeira, festa junina, baile de calouros, botequim do Pré, são atividades que procuram fortalecer a cidadania e a identidade do movimento.

Nesses cinco anos iniciais, o PVNC - Vila Operária se consolidou fisicamente e ideologicamente, ocupando um lugar de destaque no que se refere à educação popular, já que antes de sua formação, os militantes fundadores buscaram durante 1 ano entender o que é um movimento revolucionário em educação popular.

Sendo assim, o PVNC- Núcleo Vila Operária com a sua identidade formada passou a entender a importância de se inserir nos debates sobre 
políticas de ações afirmativas, mais especificamente sobre reserva de vagas para o ensino superior, tendo em vista que esse tema não era tão discutido nos primeiros anos do Núcleo.

Os impactos causados pelo PVNC - Vila Operária na comunidade também mereceram destaque nessa trajetória do Núcleo, uma vez que o espaço se tornou para alguns um local de resistência de cultura, de cidadania, de referência política, de pesquisa e de mobilidade social. Por meio do Vila Operária e de seu comprometimento, muitos alunos conseguiram alcançar espaços que pareciam distantes da realidade do filho do operariado, firmandose posteriormente no mercado de trabalho como mão de obra qualificada e não apenas mais como um trabalhador braçal.

Além disso, O PVNC - Vila Operária serviu e ainda serve como uma oficina de preparo para os desafios profissionais dos militantes, servindo assim tanto para os embates enfrentados na docência como em qualquer outra profissão desempenhada. Muitas vezes, é a porta de entrada desses ativistas em suas carreiras. Constatou-se nos depoimentos dos professores que, por meio da experiência adquirida no PVNC, durante seu período de engajamento das propostas pedagógicas, o docente sente-se mais preparado para por em prática seus conhecimentos em outras esferas, seja ela pública ou particular.

Por fim, vale destacar que o PVNC - Vila Operária, apesar da crise com que os movimentos sociais vêm sofrendo, continua desenvolvendo um trabalho de militância em busca de dias melhores. 


\section{Referências Bibliográficas}

APPLE, M. Ideologia e Currículo. São Paulo: Brasiliense, 1982.

ARENDT, $H$. Entre o passado e o futuro. São Paulo: Editora Perspectiva, 1972.

BENEVIDES, M. V. Democracia de iguais, mas diferentes. In: BORBA, A.; FARIA, N.; GODINHO, T. (Orgs.). Mulher e política - gênero e feminismo no Partido dos Trabalhadores. Editora Fundação Perseu Abramo, 1998.

BERNARDINO, J.; GALDINO, D. (Orgs.). Levando a raça a sério: Ações Afirmativas e Universidades. Rio de Janeiro: DP\&A, 2003.

BLOCH, M. Introdução à História. São Paulo: Coleção saber, publicações Europa-América, 1974.

BONI, V.; QUARESMA, S. J. Aprendendo a entrevistar: como fazer entrevistas em Ciências. Disponível em: <https://periodicos.ufsc.br>. Acesso em: 06 dez. 2014.

BRANDAO, C. R. Educação Popular. 3. ed. São Paulo: Brasiliense,1986.

CALDART, R. S. Pedagogia do Movimento Sem Terra: escola é mais do que escola. Petrópolis, RJ: Vozes, 2000.

CASTELLS, E. A sociedade em rede. 2. Ed. São Paulo: Paz e Terra, 1999.

CLAPP, A. Ação afirmativa no ensino superior: estudo da política de inserção de alunos pobres e negros na PUC-Rio. Rio de Janeiro, 2008. Tese (Doutorado em Serviço Social) - Departamento de Serviço Social, Pontifícia Universidades Católica do rio de Janeiro - PUC-Rio.

Políticas de ação afirmativa. O Social em Questão: Políticas de ação afirmativa, n.23. Rio de Janeiro. PUC-Rio, 2010.

CORBOCCI, P. O Ensino Superior Brasileiro na Década de 90. Políticas Sociais - acompanhamento e análise, n. 2, Ipea, 2001. 
DE CARVALHO, T. M. Uma abordagem ao conhecimento e a interdisciplinaridade em ciências ambientais. Rev. Acad., Ciênc. Agrár. Ambient., Curitiba, v. 7, n. 2, p. 227-235, abr./jun. 2009.

DE PAULA, M.; HERINGER, R. (Orgs.). Caminhos convergentes: Estado e Sociedade na superação das desigualdades raciais no Brasil. Rio de Janeiro: Fundação Heinrich Boll, ActionAid, 2009.

DE ROSSI, V. L. S. Projetos pedagógicos no jogo da ilusão versus esquecimento. In: Corbalán (coordinadora). Enredados por la educacion, la cultura y la política na América Latina. Buenos Aires: Editorial Biblos, 2005.

ELIAS, N. Sociedade dos indivíduos. RJ: Zahar, 1994

FERREIRA, R. O mapa das ações afirmativas no ensino superior. 2006. Disponível em: <www.politicadacor.net>. Acesso em 30 set. 2012.

FREIRE, P. Educação como prática de liberdade. Rio de Janeiro: Paz e Terra, 2001.

. Educação e Mudança. Rio de Janeiro: Paz e Terra, 1997.

Pedagogia da Autonomia: Saberes necessários à prática educativa. São Paulo: Paz e Terra, 1997.

Terra,1987.

Pedagogia do Oprimido. 27. ed. Rio de Janeiro: Paz e

GIROUX, H. Pedagogia critica como projeto de profecia exemplar. In: IMBERNÓN, F. (Org.). A educação no século XXI. Porto Alegre: Artmed, 2000.

GOHN, M. G. M. Movimentos Sociais e Educação. São Paulo: Cortez, 1992.

GOMES, J. B. B. A recepção do Instituto da Ação afirmativa pelo direito constitucional brasileiro. Revista Brasília, a. 38, n. 151 jul/set. 2001.

GOMES, J. B.; DA SILVA, F. D. L. L. As Ações Afirmativas e os Processos de Promoção da Igualdade Efetiva. Série Cadernos do CEJ; v. 24, 2003.

GRAMSCI, A. Concepção Dialética da História. 2. ed. Rio de Janeiro: Civilização Brasileira, 1978. 
GRAMSCI, A. Os Intelectuais e a Organização da Cultura. Civilização Brasileira. Rio de Janeiro, 1968.

HAAS, C. M.; LINHARES, M. Políticas públicas de ações afirmativas para ingresso na educação superior se justificam no Brasil? Rev. Bras. Est. Pedag. Brasília, v.93, n. 235, p.836-863, set/dez de 2012.

HARVEY, D. O Neoliberalismo: história e implicações. Tradução: Adail Sobral e Maria Stela Gonçalves. São Paulo: Edições Loyola, 2008.

HENRIQUES, R. Desigualdade Racial no Brasil: evolução das condições de vida na década de 90. Texto para discussão, n. 807, 2001.

MARCON, T. Políticas de ação afirmativa no contexto da sociedade brasileira. Rev. Bras. Est. Pedg. Brasilia, v.93, n.233, p.11-33, Jan/abr. 2012.

MATTOSO, J. O Brasil Desempregado. Como foram destruídos mais de 3 milhões de empregados nos anos 90. Editora: Fundação Perseu Abramo. São Paulo, 2000.

MAYO, P. Gramsci, Freire e a educação de adultos: possibilidades para uma ação transformadora. Porto Alegre: Artmed, 2004.

MINAYO, M. C. S. O desafio do conhecimento: pesquisa qualitativa em saúde. 7. ed., São Paulo: Hucitec; Rio de Janeiro: Abrasco, 2001.

MOVIMENTO DOS trabalhadores sem terra (MST). Construindo o Caminho. Secretaria Nacional MST. São Paulo, 2001.

NASCIMENTO, A. Movimentos sociais, educação e cidadania: Um Estudo sobre os Cursos Pré-Vestibulares Populares. UERJ, 1999.

ORSO, P. J. et al. Sociedade Capitalista, educação e as lutas dos trabalhadores. Editora: Outras Expressões. São Paulo, 2014.

PAIVA, I. A Dimensão educativa do fazer militante no MST. UFRN, 2004.

ROSAR, M. F. F. Sociedade Capitalista e as Lutas por uma Nova Sociedade: a atuação as Anfope. In: ORSO, P. J. et al. Sociedade Capitalista, educação e as lutas dos trabalhadores. Editora: Outras Expressões. São Paulo, 2014. 
SANTOS, R. E. Política das cotas raciais nas universidades brasileiras - 0 caso da UERJ. In: FERES JUNIOR, J.; ZONINSEIN, J. (Orgs.). Ação afirmativa e universidade: experiências nacionais comparadas. Brasília: Editora UnB, 2006.

SANTOS, R. E. Racialidade e novas formas de ação social: o prévestibular para negros e carentes. Rio de Janeiro: DP\&A/LPP-UERJ. Coleção Política da Cor, 2003.

SANTOS, R. E.; LOBATO, F. (Orgs.). Ações afirmativas: políticas públicas contra as desigualdades raciais. Rio de Janeiro: DP\&A/LPPUERJ. Coleção Política da Cor, 2003.

SAVIANI, D. Escola e democracia: teorias da educação, curvatura da vara, onze teses sobre educação e política. São Paulo: Cortez: Autores Associados. Coleção polêmicas do nosso tempo, n. 5, 1988.

SCHERER-WARREN, I. Das Mobilizações às Redes de Movimentos Sociais. Sociedade e Estado, Brasília, v. 21, n. 1, 2006.

SILVA, J. L. C. Proposta para a reforma do setor primário para a economia brasileira, 1999.

SOUZA, S. R. O pré-vestibular para negros como instrumento de política compensatória - O caso do Rio de Janeiro. In: OLIVEIRA, I. (Org.). Relações Raciais e Educação: novos desafios. DP\&A Editora, 2003.

TEIXEIRA, M. P. Negros egressos de uma universidade pública do Rio de Janeiro. Relações Raciais e Educação: novos desafios. DP\&A Editora, 2003. 